San Jose State University

SJSU ScholarWorks

Master's Theses

Master's Theses and Graduate Research

Fall 2012

\title{
Analyzing the Impact of County Radon Levels and Population Size on the Allocation of the State Indoor Radon Grant (SIRG) Funds
}

Stephen Douglas De Jong

San Jose State University

Follow this and additional works at: https://scholarworks.sjsu.edu/etd_theses

\section{Recommended Citation}

De Jong, Stephen Douglas, "Analyzing the Impact of County Radon Levels and Population Size on the Allocation of the State Indoor Radon Grant (SIRG) Funds" (2012). Master's Theses. 4229.

DOI: https://doi.org/10.31979/etd.3f7g-vrns

https://scholarworks.sjsu.edu/etd_theses/4229

This Thesis is brought to you for free and open access by the Master's Theses and Graduate Research at SJSU ScholarWorks. It has been accepted for inclusion in Master's Theses by an authorized administrator of SJSU ScholarWorks. For more information, please contact scholarworks@sjsu.edu. 


\title{
ANALYZING THE IMPACT OF COUNTY RADON LEVELS AND POPULATION SIZE ON THE ALLOCATION OF THE STATE INDOOR RADON GRANT (SIRG) FUNDS
}

\author{
A Thesis \\ Presented to \\ The Faculty of the Department of Geography \\ San Jose State University \\ In Partial Fulfillment \\ of the Requirements for the Degree \\ Master of Arts
}

by

Stephen de Jong

December 2012 
(C) 2012

Stephen de Jong

ALL RIGHTS RESERVED 


\begin{abstract}
ANALYZING THE IMPACT OF COUNTY RADON LEVELS AND POPULATION SIZE ON THE ALLOCATION OF THE STATE INDOOR RADON GRANT (SIRG) FUNDS

by Stephen de Jong
\end{abstract}

This thesis examines the SIRG program's effectiveness to target funds to states with the highest risk potential, based on county radon levels and population size. The primary method of determining the program's effectiveness was an analysis of the program's allocation of funds at a regional as well as a state level. The analysis focused on two of four input variables that the EPA utilizes in its regional allocation model (e.g., county radon levels and population size).

The analysis showed that the state-level allocation of funds is only marginally related to a combination of county radon levels and population size, while the regional allocation of funds is primarily related to a combination of these variables. An important distinction between the two allocation models was that the state-level funding includes a matching requirement of at least $40 \%$, whereas the regional funding does not require any matching. The program's dependency on the ability and willingness of state legislators to fulfill this matching requirement diminishes the effectiveness of targeting states with the highest risk potential. 
The Designated Thesis Committee Approves the Thesis Titled

ANALYZING THE IMPACT OF COUNTY RADON LEVELS AND POPULATION

SIZE ON THE ALLOCATION OF THE STATE INDOOR RADON GRANT (SIRG) FUNDS

by

Stephen de Jong

APPROVED FOR THE DEPARTMENT OF GEOGRAPHY

SAN JOSÉ STATE UNIVERSITY

December 2012

Dr. Richard Taketa

Dr. M. Kathryn Davis

Dr. Alyson Ma
Department of Geography

Department of Geography

School of Business Administration, USD 


\section{ACKNOWLEDGEMENTS}

First and foremost, I would like to thank my wife, Irene, for her unlimited support and encouragement to write this thesis. Even when all seemed lost, she encouraged me to not give up. I would also like to express my enormous gratitude to Dr. Richard Taketa, Dr. Kathryn Davis, and Dr. Alyson Ma for their time, commitment, and willingness to help me through this. Thank you so much. 


\section{TABLE OF CONTENTS}

LIST OF TABLES viii

$\begin{array}{ll}\text { LIST OF FIGURES } & \text { ix }\end{array}$

CHAPTER 1 INTRODUCTION 1

CHAPTER 2 LITERATURE REVIEW 4

$\begin{array}{ll}\text { CHAPTER } 3 \text { METHODOLOGY } & 7\end{array}$

$\begin{array}{ll}\text { Data Acquisition and Assumptions } & 7\end{array}$

Multiple Linear Regression Analysis $\quad 9$

$\begin{array}{ll}\text { Testing the Model for Assumptions } & 10\end{array}$

$\begin{array}{ll}\text { Testing the Model for Significance } & 10\end{array}$

$\begin{array}{ll}\text { The Model Coefficients } & 11\end{array}$

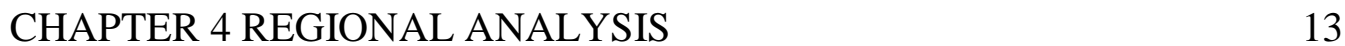

Result of Assumption Tests 13

$\begin{array}{ll}\text { Result of Significance Tests } & 17\end{array}$

$\begin{array}{ll}\text { Interpreting the Model } & 19\end{array}$

$\begin{array}{ll}\text { Discussion } & 22\end{array}$

CHAPTER 5 STATE-LEVEL ANALYSIS 25

Result of Assumption Tests 25

$\begin{array}{ll}\text { Result of Significance Tests } & 29\end{array}$

Interpreting the Model $\quad 31$

$\begin{array}{ll}\text { Discussion } & 34\end{array}$

$\begin{array}{ll}\text { CHAPTER } 6 \text { CONCLUSION } & 40\end{array}$

$\begin{array}{ll}\text { REFERENCES } & 43\end{array}$ 
Fiscal Year 2004

Fiscal Year 2005

Fiscal Year 2006 64

Fiscal Year 2007 69

Fiscal Year 2008 74

APPENDIX 2 STATE-LEVEL SPSS OUTPUTS 80

Fiscal Year 2002 80

Fiscal Year 2003 84

Fiscal Year 2004 89

Fiscal Year 2005 94

Fiscal Year 2006 99

Fiscal Year 2007 104

Fiscal Year 2008

109 


\section{LIST OF TABLES}

Table 1. Regional Durbin-Watson Test Statistics 16

$\begin{array}{ll}\text { Table 2. Regional Tolerance Values } & 17\end{array}$

$\begin{array}{ll}\text { Table 3. Regional VIF Values } & 17\end{array}$

$\begin{array}{ll}\text { Table 4. Regional F-Values } & 18\end{array}$

$\begin{array}{lr}\text { Table 5. Regional } p \text {-Values } & 18\end{array}$

Table 6. Regional $t$-Values 19

Table 7. Regional Partial Regression Coefficients 20

Table 8. Regional Coefficients of Determination $\left(R^{2}\right) \quad 21$

Table 9. State-Level Durbin-Watson Test Statistics 28

Table 10. State-Level Tolerance Values 29

Table 11. State-Level VIF Values $\quad 29$

Table 12. State-Level F-Values 30

Table 13. State-Level $p$-Values $\quad 30$

Table 14. State-Level $t$-Values

Table 15. State-Level Partial Regression Coefficients 32

Table 16. State-Level Coefficients of Determination $\left(R^{2}\right)$

Table 17. State SIRG Funding in FY 2002

Table 18. State SIRG Funding per FY 2002 Regression Model 38 


\section{LIST OF FIGURES}

Figure 1. Map of EPA Regions (excluding overseas territories) 1

Figure 2. EPA Map of Radon Zones (EPA, 2004a) 5

Figure 3. Allocation of SIRG Funds $\quad 9$

$\begin{array}{lll}\text { Figure 4. Regional Scatterplots for FY } 2002 & 13\end{array}$

$\begin{array}{lll}\text { Figure 5. Regional Residual Plot for FY } 2004 & 14\end{array}$

Figure 6. Regional Normal P-P Plot and Histogram of the Residuals for FY 2006

Figure 7. Population Size per EPA Region from 2002 to 2008

Figure 8. SIRG Funding per EPA Region from 2002 to 200823

Figure 9. State-Level Scatterplots for FY 2002

Figure 10. Scatterplots for Participating States in FY 2002

Figure 11. State-Level Residual Plot for FY 2004

Figure 12. State-Level Normal P-P Plot and Histogram of the Residuals for FY $2006 \quad 28$

Figure 13. State SIRG Funding for EPA Region $3 \quad 36$ 


\section{Chapter 1 Introduction}

The State Indoor Radon Grant (SIRG) program was established in 1988 and is administered by the U.S. Environmental Protection Agency (EPA). The program's major objectives are to assess indoor radon levels, increase public awareness of radon, and to reduce health risks associated with indoor radon (Marcinowski, 1995). The program annually provides around 8 million dollars, which is distributed to the regional officers of the 10 EPA regions (Figure 1). The regional officers then redistribute these funds among the states located within their respective regions.

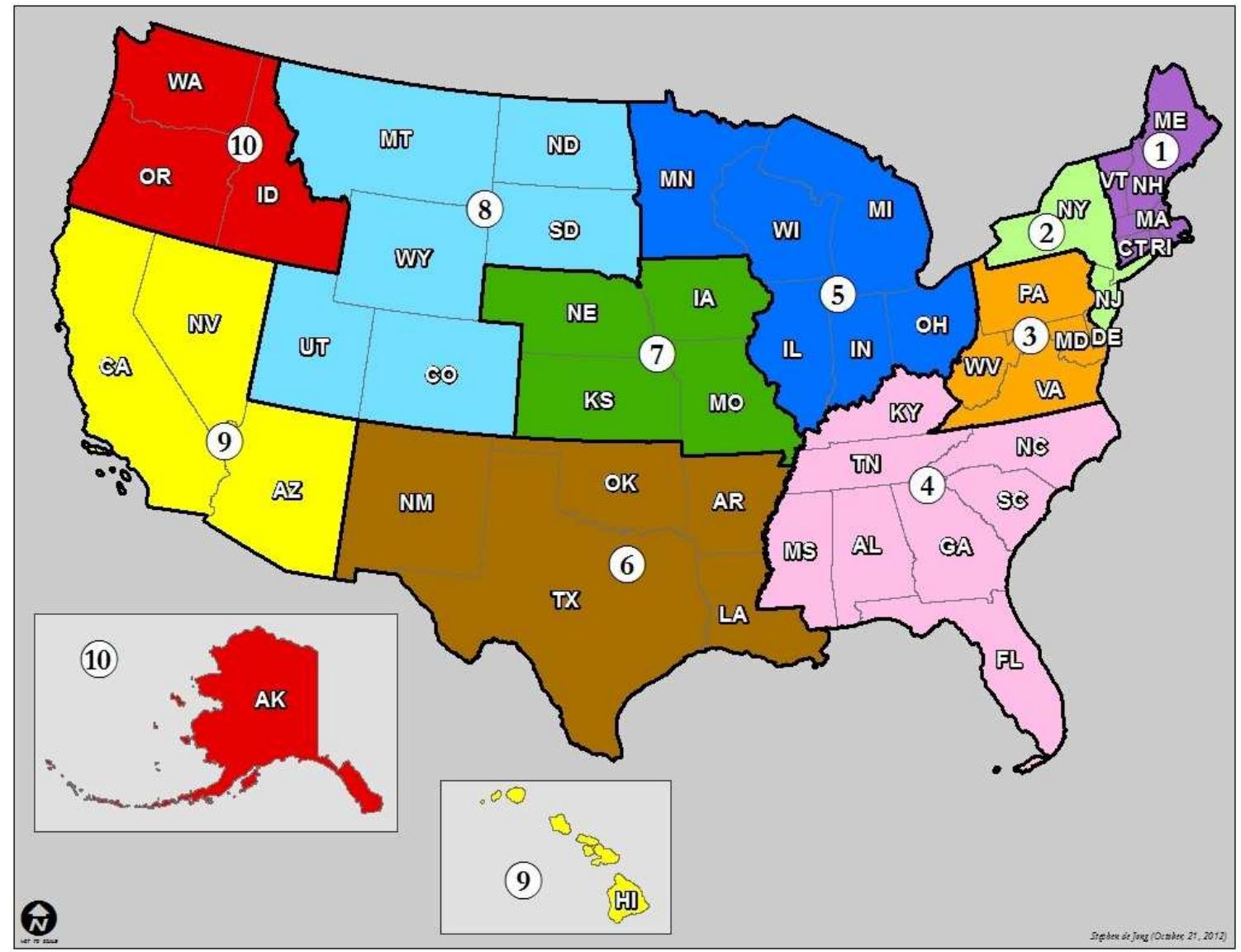

Figure 1. Map of EPA Regions (excluding overseas territories) 
The state agencies receive funding based on project proposals. Once projects are approved by the EPA, grants are usually only allocated if the respective state can match the EPA grant amount by a minimum of $40 \%$. Typically, these grants are put to use on state-level programs, such as education, training, or radon awareness programs. A small portion of the funds is sometimes further allocated to counties, cities, or nonprofit organizations (U.S. Environmental Protection Agency [EPA], 2005).

In 1995, the EPA's strategy for its radon program was to focus resources and initiatives aimed at targeting the greatest risk areas and populations. Examples of then recently completed and ongoing activities included: "developing and releasing the Map of Radon Zones, and targeting State Indoor Radon Grant (SIRG) funds to highest risk geographic areas and populations" (Marcinowski, 1995, p. I-2.8). Later, the EPA started creating models each year, on which the allocation of SIRG funds was to be based. Inputs to the formula of these models included population size, distribution of county radon zone designations, smoking rates, and a state's success in previous years of the SIRG program. However, the EPA points out that these models do not affect the SIRG application or award process. They only apply to the regional allocation of funds and not to the state-level allocation of funds (EPA, 2005).

Likely, the SIRG program will cease to exist in 2013. Due to the current federal budget crisis, President Obama's budget proposal for fiscal year 2013 includes substantial cutbacks in environmental protection programs, which includes the elimination of funding for the SIRG program altogether. As a result, the overall EPA budget for radon would drop from $\$ 8$ million to $\$ 2$ million (EPA, 2012b). 
This thesis examines the SIRG program's effectiveness of targeting funds to states with the highest risk potential, based on county radon levels and population size. The fact that no models are applied to the state allocation of funds implies that some degree of randomness is involved in the distribution. The question therefore arises whether the EPA is still able to effectively target SIRG funds to the greatest risk areas and populations. The primary method of determining the program's effectiveness was an analysis of the program's allocation of funds. The analysis focused on two of four input variables that the EPA utilizes in its regional model (e.g., county radon levels and population size). At a regional as well as a state level, this thesis analyzes whether the SIRG funds are indeed significantly impacted by county radon levels and population size. 


\section{Chapter 2 Literature Review}

Radon is a radioactive gas released from the natural decay of uranium in rocks and soil. It is an invisible, odorless, tasteless gas that seeps up through the ground and diffuses into the air. The gas is present in all 50 of the United States and usually exists at very low levels outdoors. However, it can also enter homes through cracks in floors, walls, or foundations (EPA, 2012a). Radon can pose serious health risks when inhaled over a long period of time. It is the second leading cause of lung cancer and is attributed to the death of an estimated 15,000 to 22,000 Americans each year (National Research Council, 1999). The presence of indoor radon does not display any immediate symptoms. Typically, problems do not surface until years of exposure to radon. The only way to determine indoor radon levels is through testing.

Obtaining accurate information on indoor radon levels is extremely important to radon officials and researchers. Currently, the most used and readily available map of indoor radon levels is the "EPA Map of Radon Zones" (Figure 2). The EPA developed the map to assist National, State, and local organizations to target their resources and to implement radon-resistant building codes (Marcinowski, 1995). The map assigns each of the 3,141 counties in the U.S. to one of three zones based on radon potential:

- Zone 1 counties have a predicted average indoor radon screening level greater than $4 \mathrm{pCi} / \mathrm{L}$ (pico curies per liter)

- Zone 2 counties have a predicted average indoor radon screening level between 2 and $4 \mathrm{pCi} / \mathrm{L}$

- Zone 3 counties have a predicted average indoor radon screening level less than $2 \mathrm{pCi} / \mathrm{L}$ 
Since potential radon levels are based on county averages, the EPA warns that these figures are by no means to be used as an indicator for radon levels at specific locations. Many thousands of individual homes with elevated (e.g., zone 1) radon levels can be found in zone 2 as well as in zone 3 (EPA, 2004b).

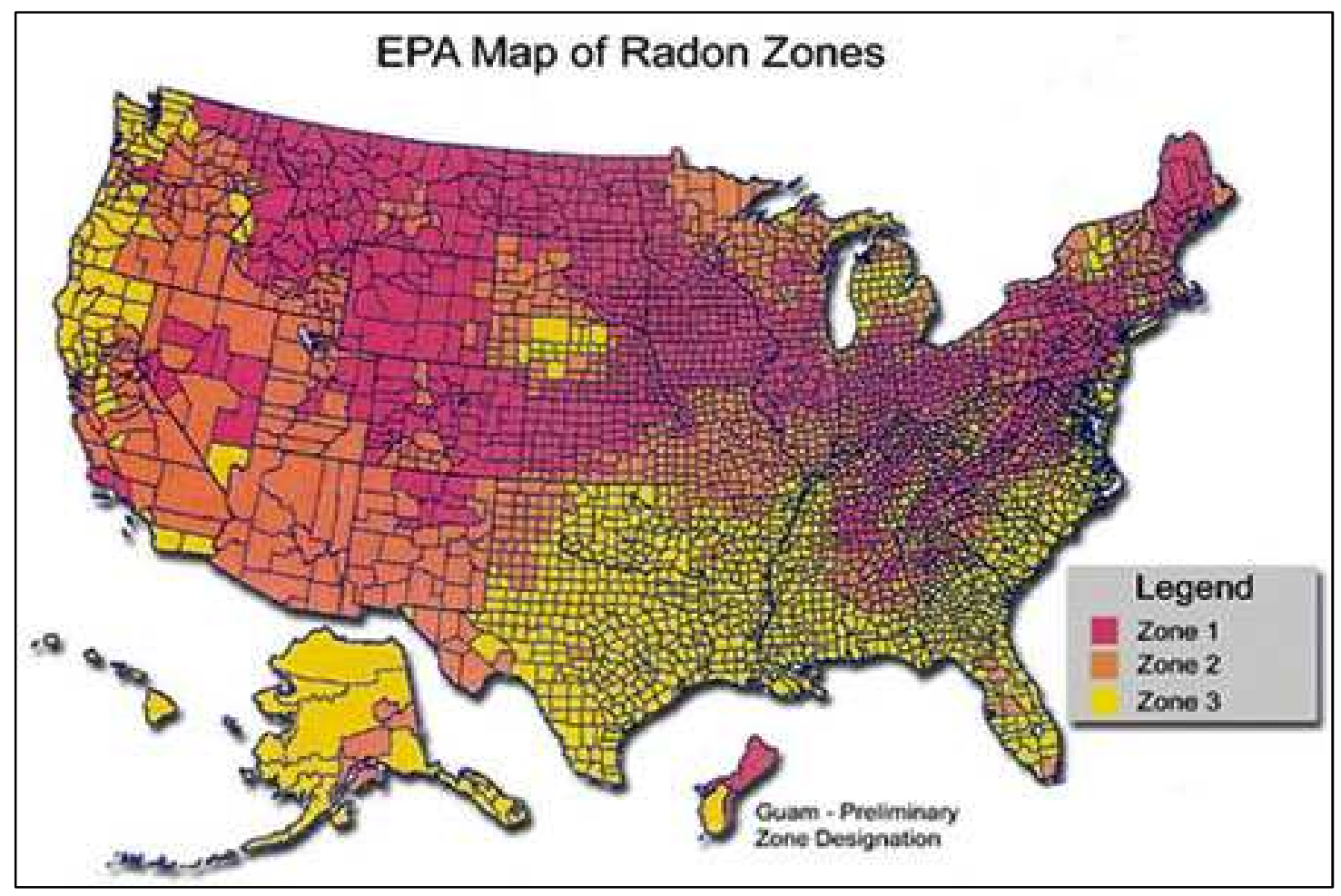

Figure 2. EPA Map of Radon Zones (EPA, 2004a)

Much larger scale and more detailed maps than the "EPA Map of Radon Zones" are necessary to more accurately identify residential radon levels (Christensen \& Rigby, 1995; Nielson, Holt, \& Rogers, 1995; Price, Nero, \& Boscardin, 1993). Christensen and Rigby (1995) reported that due to a lack of accurate local radon level data, the State of Nevada in conjunction with the Nevada Bureau of Mines and Geology implemented a comprehensive program to acquire more detailed radon data in Nevada. The methods used were a survey that tested indoor radon levels in 2,500 homes and a program that 
included remote sensing technologies to measure outdoor radon levels. Nielson et al. (1995) also found that new approaches are needed to more accurately and more easily map indoor radon levels. The methodology they described is a model that calculates potential indoor radon levels based on the top 5 meters of surface soil on which a house is built. According to Price et al. (1993) the most significant predictive factors on residential radon levels are:

1. Living in the Northern United States.

2. Having a basement that is used as living space.

3. Living in an area with soil or bedrock that has an extremely high radium concentration.

4. Living in an area with very high soil permeability.

Having detailed what radon is, how radon is measured, what the SIRG program is, and how the EPA allocates the SIRG funds, the next step is to analyze whether the funding is indeed related to county radon levels and population size. The next chapter describes the methodology used in this research. 


\section{Chapter 3 Methodology}

\section{Data Acquisition and Assumptions}

The following 3 types of secondary data were obtained from the U.S. Census Bureau and the U.S. Environmental Protection Agency for the 10 EPA regions as well as the 50 states plus the District of Columbia:

1. $\quad$ SIRG funding (EPA, 2011)

2. County radon levels (EPA, 2004a)

3. County population sizes (U.S. Census Bureau, 2010)

The research focused on the fiscal years 2002 through 2008 of the SIRG program, which covers 7 out of 23 (or 30\%) of the program's completed fiscal years.

At a first glance, this research included only 3 variables: SIRG funding, county radon levels, and population size. One of the constraints, however, was that the county radon level data are ordinal, which is a qualitative measurement (e.g., zone 1, zone 2, and zone 3). This meant that no state and regional averages of the county radon levels could be obtained, since no arithmetic can be applied to qualitative data. In order to incorporate an ordinal variable into multiple regression analysis, the variable needed to be transformed into a quantitative variable. This was achieved by using the frequency, which is the number of counties with respectively zone 1, zone 2, and zone 3 radon levels for each EPA region and state. As a result, this research used 5 variables, which are defined as follows:

- $\mathrm{x}_{1}$ is the number of counties per EPA region or state with zone 1 radon levels. Zone 1 radon levels are considered high, which means a predicted average indoor radon screening level greater than $4 \mathrm{pCi} / \mathrm{L}$. 
- $\mathrm{x}_{2}$ is the number of counties per EPA region or state with zone 2 radon levels. Zone 2 radon levels are considered medium, which means a predicted average indoor radon screening level between 2 and $4 \mathrm{pCi} / \mathrm{L}$.

- $\mathrm{x}_{3}$ is the number of counties per EPA region or state with zone 3 radon levels. Zone 3 radon levels are considered low, which means a predicted average indoor radon screening level less than $2 \mathrm{pCi} / \mathrm{L}$.

- $\mathrm{x}_{4}$ is the population size of an EPA region or state during a particular fiscal year.

- $\mathrm{Y}$ is the dollar amount per fiscal year allocated through the SIRG program to an EPA region or state.

The analysis was divided into two parts. The first part includes an analysis of the regional funding and the second part includes an analysis of the state-level funding. This distinction was made because the SIRG funding is actually allocated twice before reaching the states. First, staff at the EPA headquarters in Washington D.C. allocates the funding to the 10 official EPA regions. Next, the EPA region coordinators allocate the funding to the respective states within their region (Figure 3). Therefore the possibility exists that one part of the allocation of SIRG funds may be related to county radon levels and population size, whereas the other part may not be related to these variables. 


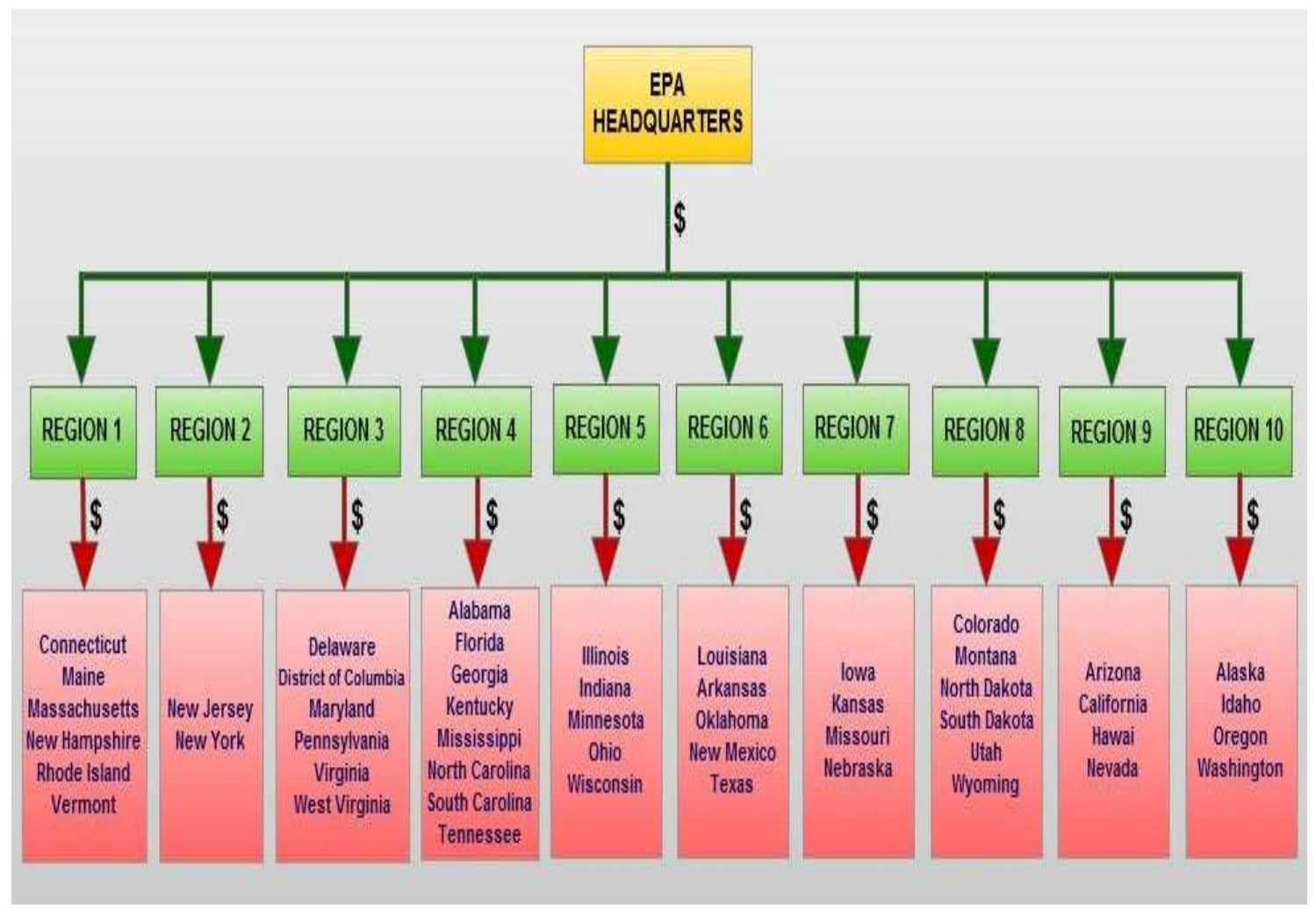

Figure 3. Allocation of SIRG Funds

\section{Multiple Linear Regression Analysis}

This research used the standard multiple linear regression analysis to determine whether county radon levels and population size have a significant influence on the level of SIRG funding. SIRG funding was selected as the dependent variable and population size and the number of counties with respectively high, medium, and low radon levels were selected as the independent variables. Standard multiple linear regression was chosen, since initial observations did not indicate that any of the independent variables would have a higher impact on the dependent variable. The same multiple regression model was used to determine the effect of the independent variables on the dependent variable for each of the 7 observed fiscal years:

$$
Y=b_{0}+b_{1} x_{1}+b_{2} x_{2}+b_{3} x_{3}+b_{4} x_{4}+e
$$


Where,

- $\quad \mathrm{Y}=\mathrm{SIRG}$ funding

$-\mathrm{x}_{1}=$ Number of counties with zone 1 (high) radon levels

$-\mathrm{x}_{2}=$ Number of counties with zone 2 (medium) radon levels

$-\mathrm{x}_{3}=$ Number of counties with zone 3 (low) radon levels

- $\mathrm{x}_{4}=$ Population size

- $b_{0}, b_{1}, b_{2}, b_{3}, b_{4}=$ Regression coefficients

- $\mathrm{e}=$ Random error

\section{Testing the Model for Assumptions}

Regression models are most effective at identifying relationships between a combination of independent variables and a dependent variable when its underlying assumptions are satisfied. This research used five principal assumptions which justify the use of a multiple linear regression model for purposes of prediction and estimation:

1. Linearity

2. Homoscedasticity

3. Normality

4. Autocorrelation

5. Multicollinearity

If any of these assumptions is violated, the regression model may be (at best) inefficient or (at worst) seriously biased or misleading.

\section{Testing the Model for Significance}

In order to determine whether the independent variables had a significant impact on the dependent variable, the $F$-test and $t$-test were applied to each of the models. The $F$-test was used to examine the relationship between the dependent variable and the set of independent variables, and the $t$-test was used to examine the relationship of each individual independent variable with the dependent variable. The value of $F$ was 
obtained through the ANOVA calculation in SPSS, and the value of $t$ was obtained from the coefficients table calculated in SPSS.

\section{The Model Coefficients}

The partial regression coefficients of the model predict the amount by which the dependent variable increases when one independent variable is increased by one unit and all the other independent variables are held constant. This coefficient is called partial because its value depends, in general, upon the other independent variables. Specifically, the value of the partial coefficient for one independent variable will vary, in general, depending upon the other independent variables included in the regression equation. The partial regression coefficients were obtained from the coefficients table calculated in SPSS.

The multiple correlation coefficient is used in multiple regression analysis to assess the quality of the prediction of the dependent variable. It corresponds to the squared correlation between the predicted and the actual values of the dependent variable. The multiple correlation coefficient, which is usually represented by the letter $R$, estimates the combined influence of two or more independent variables on the dependent variable. The coefficient is:

- 0 , if no relationship exists;

- 1 , if a perfect positive correlation exists;

- -1 , if a perfect negative correlation exists;

- Between 0 and 1, if some positive correlation exists;

- Between -1 and 0 , if some negative correlation exists.

Lastly, the coefficient of determination $\left(R^{2}\right)$ was analyzed. This coefficient shows how well a regression model fits the data. Its value ranges from 0 to 1 , and represents the 
proportion of variation that can be explained by the regression equation. A value of 1 implies a perfect fit of the model to explain the variation, and a value of 0 implies the model does not explain the variation at all. The multiple correlation coefficient $(R)$ and the coefficient of determination $\left(R^{2}\right)$ were both obtained from the model summary calculated in SPSS. 


\section{Chapter 4 Regional Analysis}

\section{Result of Assumption Tests}

Plotting each independent variable against the dependent variable provided insight into the linearity of the relationships. The independent variables "Number of counties with zone 1 (high) radon levels," "Number of counties with zone 2 (medium) radon levels," and "Population size" all showed a relatively strong positive linear relationship with the dependent variable "SIRG funding." The relationship between "Number of counties with zone 3 (low) radon levels" and "SIRG funding" proved to be the least linear. If anything, it displayed either a very weak negative linear relationship or no relationship at all. The relationships between the variables proved very similar for each observed fiscal year. Figure 4 shows the scatterplots for each independent variable with the dependent variable for FY 2002.

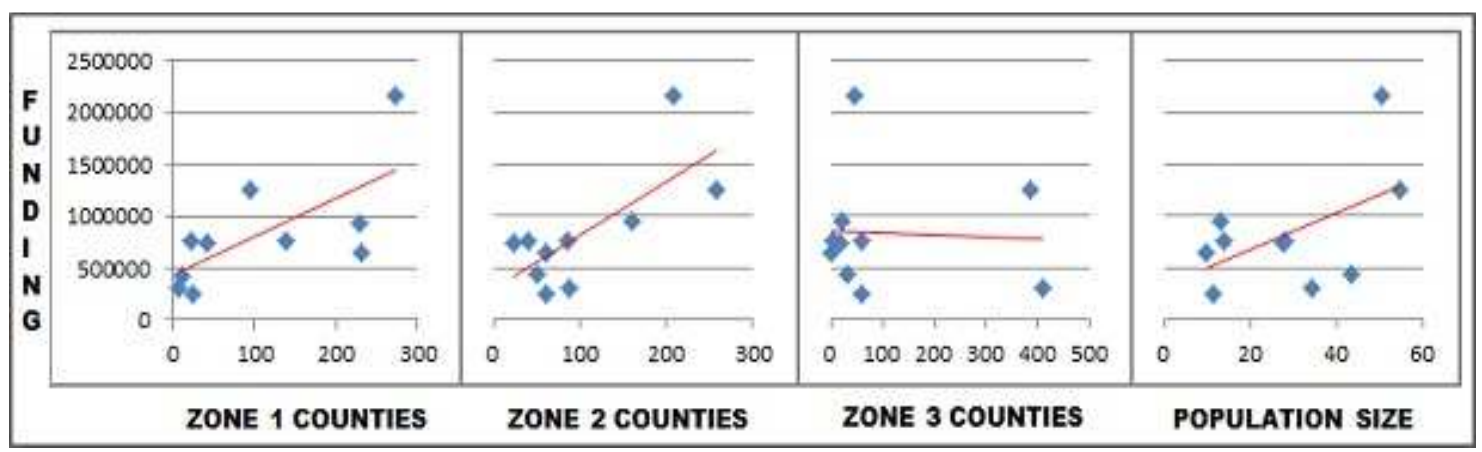

Figure 4. Regional Scatterplots for FY 2002

The residuals were plotted against the predicted value of the dependent variable for each fiscal year to assess the assumption of homoscedasticity. As illustrated in Figure 5, the data points of the plot for FY 2004 are randomly dispersed around the x-axis and do not form any obvious pattern. This means that the errors had constant variance and 
that the assumption of homoscedasticity was met. The scatterplots of the other fiscal years showed similar results.

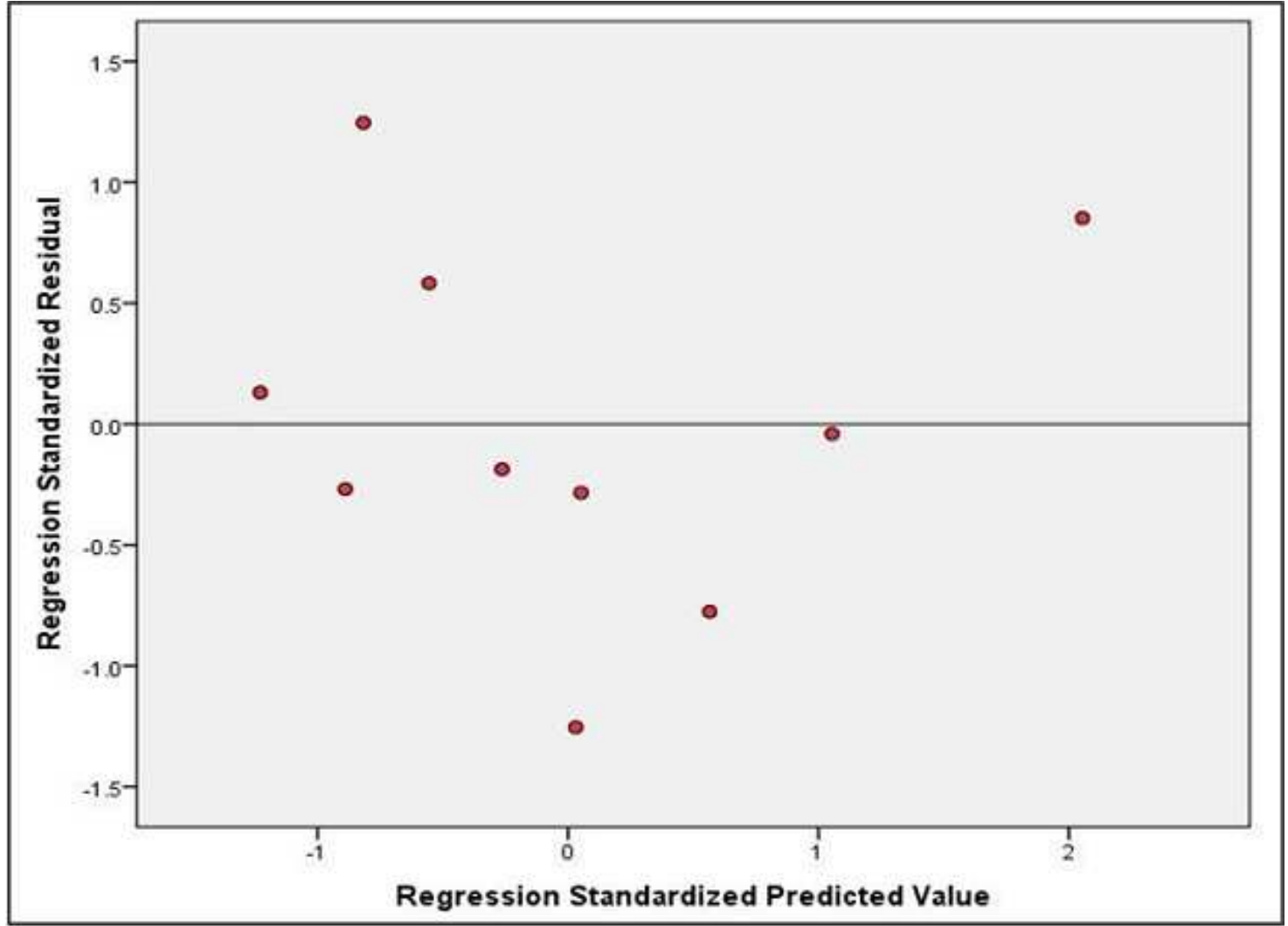

Figure 5. Regional Residual Plot for FY 2004

A histogram and P-P plot of the residuals (predicted minus observed values) were created in SPSS to test for normality of the error term. In order to pass this normality test, the P-P plotted residuals should closely follow the diagonal or 45 degree reference line, and the shape of the histogram should approximately follow the shape of the normal (bell) curve. The regression models for all 7 fiscal years passed the normality test and showed very similar results. Figure 6 displays the P-P plot and histogram of the residuals for FY 2006. The graphic examples illustrate quite well that the data points of the P-P 
plot closely follow the diagonal line and that the shape of the histogram closely matches the shape of the normal (bell) curve.

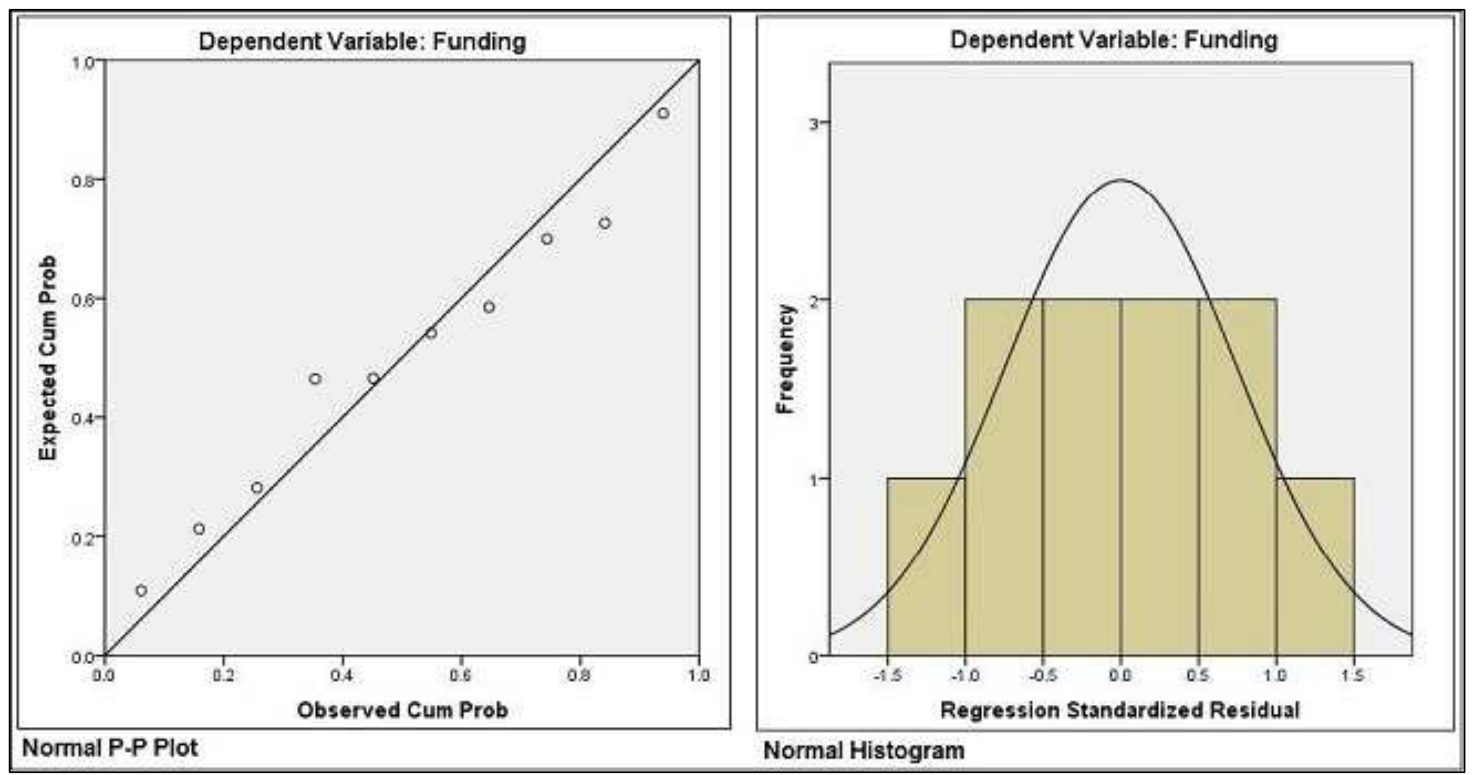

Figure 6. Regional Normal P-P Plot and Histogram of the Residuals for FY 2006

The Durbin-Watson test statistic was analyzed to test for autocorrelation. All 7 regression models in the regional part of the analysis included a sample size of 10 (e.g., 10 EPA regions) and 4 explanatory variables (e.g., "Number of counties with zone 1 (high) radon levels," "Number of counties with zone 2 (medium) radon levels," "Number of counties with zone 3 (low) radon levels," and "Population size"). With $N=10$ and $k \square$ $=4$, the Durbin-Watson table at the $5 \%$ significance level showed $d L=0.376$ and $d U=$ 2.414 (Anderson, Sweeney, \& Williams, 1997, p. B-28). These are the critical values of the Durbin-Watson test statistic, with $d L$ being the lower bound and $d U$ the upper bound.

Table 1 shows that all Durbin-Watson test statistics were between the lower and upper bound (0.376 and 2.414 respectively), which means that the test was inconclusive regarding the existence of autocorrelation in any of the regression models. However, the 
existence of autocorrelation was highly unlikely, since no time series was involved, as all of the regression models in this research applied to only one fiscal year.

Table 1. Regional Durbin-Watson Test Statistics

\begin{tabular}{|c|c|c|c|c|c|c|c|}
\hline & $\mathbf{2 0 0 2}$ & $\mathbf{2 0 0 3}$ & $\mathbf{2 0 0 4}$ & $\mathbf{2 0 0 5}$ & $\mathbf{2 0 0 6}$ & $\mathbf{2 0 0 7}$ & $\mathbf{2 0 0 8}$ \\
\hline $\begin{array}{c}\text { Durbin-Watson } \\
\text { Test Statistic }\end{array}$ & 1.07 & 1.59 & 1.17 & 0.84 & 0.81 & 1.13 & 0.88 \\
\hline
\end{tabular}

The regression model for each of the fiscal years proved to be free of multicollinearity. As shown in Table 2 and Table 3, the tolerance measure of each explanatory variable was consistently higher than 0.2 , and the VIF values were consistently less than 10 . The variable with the highest multicollinearity was "Number of counties with zone 2 (medium) radon levels." With values consistently around 4.5 , the variable easily met the VIF requirement, but with a tolerance value of 0.22 in each fiscal year, it just barely met the tolerance requirement. The variable "Population size" had the lowest multicollinearity. Its tolerance value was consistently around 0.5 , and its VIF value was close to 2 in each fiscal year. The conclusion is that the model passed the test for multicollinearity in each of the observed fiscal years, since all the SPSS calculated values for tolerance and VIF met the requirements. 
Table 2. Regional Tolerance Values

\begin{tabular}{|c|c|c|c|c|c|c|c|}
\hline & $\mathbf{2 0 0 2}$ & $\mathbf{2 0 0 3}$ & $\mathbf{2 0 0 4}$ & $\mathbf{2 0 0 5}$ & $\mathbf{2 0 0 6}$ & $\mathbf{2 0 0 7}$ & $\mathbf{2 0 0 8}$ \\
\hline $\begin{array}{c}\text { \# Zone 1 } \\
\text { Counties }\end{array}$ & 0.32 & 0.32 & 0.32 & 0.32 & 0.32 & 0.32 & 0.32 \\
\hline $\begin{array}{c}\text { \# Zone 2 } \\
\text { Counties }\end{array}$ & 0.22 & 0.22 & 0.22 & 0.22 & 0.22 & 0.22 & 0.22 \\
\hline $\begin{array}{c}\text { \# Zone 3 } \\
\text { Counties }\end{array}$ & 0.39 & 0.39 & 0.39 & 0.39 & 0.39 & 0.39 & 0.39 \\
\hline $\begin{array}{c}\text { Population } \\
\text { Size }\end{array}$ & 0.50 & 0.50 & 0.50 & 0.49 & 0.48 & 0.48 & 0.47 \\
\hline
\end{tabular}

Table 3. Regional VIF Values

\begin{tabular}{|c|c|c|c|c|c|c|c|}
\hline & $\mathbf{2 0 0 2}$ & $\mathbf{2 0 0 3}$ & $\mathbf{2 0 0 4}$ & $\mathbf{2 0 0 5}$ & $\mathbf{2 0 0 6}$ & $\mathbf{2 0 0 7}$ & $\mathbf{2 0 0 8}$ \\
\hline $\begin{array}{c}\text { \# Zone 1 } \\
\text { Counties }\end{array}$ & 3.09 & 3.10 & 3.11 & 3.12 & 3.13 & 3.13 & 3.13 \\
\hline $\begin{array}{c}\text { \# Zone 2 } \\
\text { Counties }\end{array}$ & 4.51 & 4.51 & 4.52 & 4.54 & 4.56 & 4.56 & 4.55 \\
\hline $\begin{array}{c}\text { \# Zone 3 } \\
\text { Counties }\end{array}$ & 2.59 & 2.59 & 2.59 & 2.59 & 2.59 & 2.60 & 2.60 \\
\hline $\begin{array}{c}\text { Population } \\
\text { Size }\end{array}$ & 1.99 & 2.00 & 2.02 & 2.04 & 2.07 & 2.10 & 2.11 \\
\hline
\end{tabular}

\section{Result of Significance Tests}

The critical value of $F$ was approximately 5.19 for a $95 \%$ confidence interval

(Anderson et al., 1997, p. B-6). Since all fiscal years had identical regression and error in the degrees of freedom, the critical value of $F$ could be applied to the models of all observed fiscal years. Table 4 demonstrates that the $F$ values of all fiscal years except FY 2003 were greater than the critical $F$ value of 5.19 . 
Table 4. Regional $F$-Values

\begin{tabular}{|c|c|c|c|c|c|c|c|}
\hline & $\mathbf{2 0 0 2}$ & $\mathbf{2 0 0 3}$ & $\mathbf{2 0 0 4}$ & $\mathbf{2 0 0 5}$ & $\mathbf{2 0 0 6}$ & $\mathbf{2 0 0 7}$ & $\mathbf{2 0 0 8}$ \\
\hline $\begin{array}{c}\boldsymbol{F}- \\
\text { value }\end{array}$ & 6.09 & 3.90 & 5.31 & 6.35 & 5.45 & 5.24 & 5.59 \\
\hline
\end{tabular}

Therefore, the conclusion is that in each fiscal year except FY 2003, the set of independent variables was indeed related to the dependent variable. However, for FY 2003 the null hypothesis was accepted as $F$ was only 3.90, which is less than the critical value of $F$. The same conclusion is made from the significance test values of $p$ in the SPPS calculated ANOVA. The value $p$ needed to be less than 0.05 for a $95 \%$ confidence interval in order for the model to be significant. As shown in Table 5, $p$ was less than 0.05 for each fiscal year except for FY 2003.

Table 5. Regional $p$-Values

\begin{tabular}{|c|c|c|c|c|c|c|c|}
\hline & $\mathbf{2 0 0 2}$ & $\mathbf{2 0 0 3}$ & $\mathbf{2 0 0 4}$ & $\mathbf{2 0 0 5}$ & $\mathbf{2 0 0 6}$ & $\mathbf{2 0 0 7}$ & $\mathbf{2 0 0 8}$ \\
\hline $\begin{array}{c}\boldsymbol{p}- \\
\text { value }\end{array}$ & 0.037 & 0.084 & 0.048 & 0.034 & 0.046 & 0.049 & 0.043 \\
\hline
\end{tabular}

The critical values for $t$ were -2.57 and 2.57 for a $95 \%$ confidence interval (Anderson et al., 1997, p. B-3). Table 6 demonstrates that the $t$ values for all independent variables in each fiscal year were within the lower and upper bound of the critical $t$ value (-2.57 and 2.57 respectively), which means that all variables failed the $t$-test. Therefore, the conclusion is that none of the independent variables individually had a significant relationship with the dependent variable. The same conclusion is made from the coefficients table processed in SPSS. The significance test value $p$ was greater than 0.05 
for all of the individual independent variables in each fiscal year for a $95 \%$ confidence interval.

Table 6. Regional $t$-Values

\begin{tabular}{|c|c|c|c|c|c|c|c|}
\hline & $\mathbf{2 0 0 2}$ & $\mathbf{2 0 0 3}$ & $\mathbf{2 0 0 4}$ & $\mathbf{2 0 0 5}$ & $\mathbf{2 0 0 6}$ & $\mathbf{2 0 0 7}$ & $\mathbf{2 0 0 8}$ \\
\hline $\begin{array}{c}\text { \# Zone 1 } \\
\text { Counties }\end{array}$ & 0.97 & 0.40 & 0.63 & 0.78 & 0.33 & 0.48 & 0.39 \\
\hline $\begin{array}{c}\text { \# Zone 2 } \\
\text { Counties }\end{array}$ & 1.25 & 1.33 & 1.38 & 1.49 & 1.62 & 1.22 & 1.45 \\
\hline $\begin{array}{c}\text { \# Zone3 } \\
\text { Counties }\end{array}$ & -1.42 & -1.36 & -1.51 & -1.41 & -1.16 & -1.20 & -1.27 \\
\hline $\begin{array}{c}\text { Population } \\
\text { Size }\end{array}$ & 1.76 & 1.29 & 1.60 & 1.65 & 1.51 & 2.01 & 1.86 \\
\hline
\end{tabular}

Based on the significance test results obtained from the $F$-test and the $t$-test, the conclusion is that the independent variables were related to the dependent variable collectively but not individually. Thus, the model was significant, but the individual relationships between the dependent and the independent variables were not significant. The exception was FY 2003, where neither the model nor the relationships between the variables were significant.

\section{Interpreting the Model}

Table 7 shows the partial regression coefficients for the regression models of each observed fiscal year. These coefficients were obtained from the individual coefficient tables in SPPS. Even though the $t$-test revealed that no statistically significant relationship existed between the dependent variable and any of the independent variables individually, the coefficients were still useful to further interpret each of the regression models. 
Table 7. Regional Partial Regression Coefficients

\begin{tabular}{|c|c|c|c|c|c|c|c|}
\hline & $\mathbf{2 0 0 2}$ & $\mathbf{2 0 0 3}$ & $\mathbf{2 0 0 4}$ & $\mathbf{2 0 0 5}$ & $\mathbf{2 0 0 6}$ & $\mathbf{2 0 0 7}$ & $\mathbf{2 0 0 8}$ \\
\hline Constant & 2,191 & $-74,318$ & $-44,295$ & 61,108 & 79,248 & 36,152 & 29,529 \\
\hline $\begin{array}{c}\text { \# Zone 1 } \\
\text { Counties }\end{array}$ & 1,703 & 1,038 & 1,290 & 1,327 & 562 & 831 & 685 \\
\hline $\begin{array}{c}\text { \# Zone 2 } \\
\text { Counties }\end{array}$ & 3,497 & 5,489 & 4,476 & 4,041 & 4,428 & 3,367 & 4,062 \\
\hline $\begin{array}{c}\text { \# Zone3 } \\
\text { Counties }\end{array}$ & $-1,518$ & $-2,138$ & $-1,857$ & $-1,447$ & $-1,197$ & $-1,253$ & $-1,352$ \\
\hline $\begin{array}{c}\text { Population } \\
\text { Size }\end{array}$ & 0.015 & 0.016 & 0.016 & 0.013 & 0.012 & 0.016 & 0.015 \\
\hline
\end{tabular}

The regression models for each of the fiscal years were derived from the data in

Table 7. The following is an example of the regression model for FY 2008:

$$
Y=29,529+685 x_{1}+4,062 x_{2}-1,352 x_{3}+0.015 x_{4}
$$

Where,

$-\mathrm{Y}=$ SIRG funding

$-\mathrm{x}_{1}=$ Number of counties with zone 1 (high) radon levels

$-\mathrm{x}_{2}=$ Number of counties with zone 2 (medium) radon levels

$-\mathrm{x}_{3}=$ Number of counties with zone 3 (low) radon levels

$-\mathrm{x}_{4}=$ Population size

For FY 2008, the model can be interpreted as follows:

- A constant $(\alpha)$ of 29,529 means that if all of the independent variables are equal to zero, then the variable "SIRG funding" (Y) will increase by $\$ 29,529$;

- If all other independent variables remain constant or are equal to zero, an increase of one unit in the variable "Number of counties with zone 1 (high) radon levels" $\left(\mathrm{x}_{1}\right)$ will result in an average increase of $\$ 685$ in "SIRG funding" (Y);

- If all other independent variables remain constant or are equal to zero, an increase of one unit in the variable "Number of counties with zone 2 
(medium) radon levels" $\left(\mathrm{x}_{2}\right)$ will result in an average increase of $\$ 4,062$ in "SIRG funding" (Y);

- If all other independent variables remain constant or are equal to zero, an increase of one unit in the variable "Number of counties with zone 3 (low) radon levels" $\left(\mathrm{x}_{3}\right)$ will result in an average decrease of $\$ 1,352$ in "SIRG funding" (Y);

- If all other independent variables remain constant or are equal to zero, an increase of one unit in the variable "Population size" $\left(\mathrm{x}_{4}\right)$ will result in an average increase of $\$ 0.015$ in "SIRG funding" (Y).

The coefficient of determination is identified by $R^{2}$, which is the correlation coefficient quadrate. $R^{2}$ explains the total variation in the dependent variable caused by all the independent variables combined. As shown in Table 8, the $R^{2}$ for FY 2002 was 0.83. This means that $83 \%$ of the variation in the dependent variable "SIRG funding" was caused by the independent variables "Number of counties with zone 1 (high) radon levels", "Number of counties with zone 2 (medium) radon levels," "Number of counties with zone 3 (low) radon levels," and "Population size." The remaining $17 \%$ of the variation in "SIRG funding" was caused by factors that weren't represented in the model. The models for the other fiscal years showed very similar results with all of them having coefficients of determination between 0.81 and 0.84 . The coefficient of determination for FY 2003 was ignored, since the model for FY 2003 did not pass the $F$-test and $p$ was greater than 0.05 for the $95 \%$ confidence interval.

Table 8. Regional Coefficients of Determination $\left(R^{2}\right)$

\begin{tabular}{|l|c|c|c|c|c|c|c|}
\hline & $\mathbf{2 0 0 2}$ & $\mathbf{2 0 0 3}$ & $\mathbf{2 0 0 4}$ & $\mathbf{2 0 0 5}$ & $\mathbf{2 0 0 6}$ & $\mathbf{2 0 0 7}$ & $\mathbf{2 0 0 8}$ \\
\hline $\boldsymbol{p}$ & 0.037 & 0.084 & 0.048 & 0.034 & 0.046 & 0.049 & 0.043 \\
\hline $\boldsymbol{R}^{2}$ & 0.83 & 0.76 & 0.81 & 0.84 & 0.81 & 0.81 & 0.82 \\
\hline
\end{tabular}




\section{Discussion}

The multiple regression analysis at the regional level demonstrated that the independent variables had a significant combined effect on the dependent variable "SIRG funding." Individually, however, these variables did not have a significant effect on "SIRG funding." Since the coefficients of determination had values greater than 0.8 for the 6 significant models, this indicates that less than $20 \%$ of "SIRG funding" was attributed to variables other than county radon levels and population size. Therefore, the conclusion is that the regional allocation of funds for the 6 significant models was indeed predominantly based on county radon levels and population size.

An interesting observation was that the model for FY 2003 was the only model that failed the significance test. To better understand why this was the case, a comparison of the values for the variables "Population size" and "SIRG funding" was made for each of the observed fiscal years. The variables regarding the number of counties with respectively low, medium, and high radon levels were not more closely examined, as the values of these variables remained constant throughout the 7 observed fiscal years. Figure 7 shows the population size per EPA region for each fiscal year and Figure 8 shows the SIRG funding amount per EPA region for each fiscal year. 


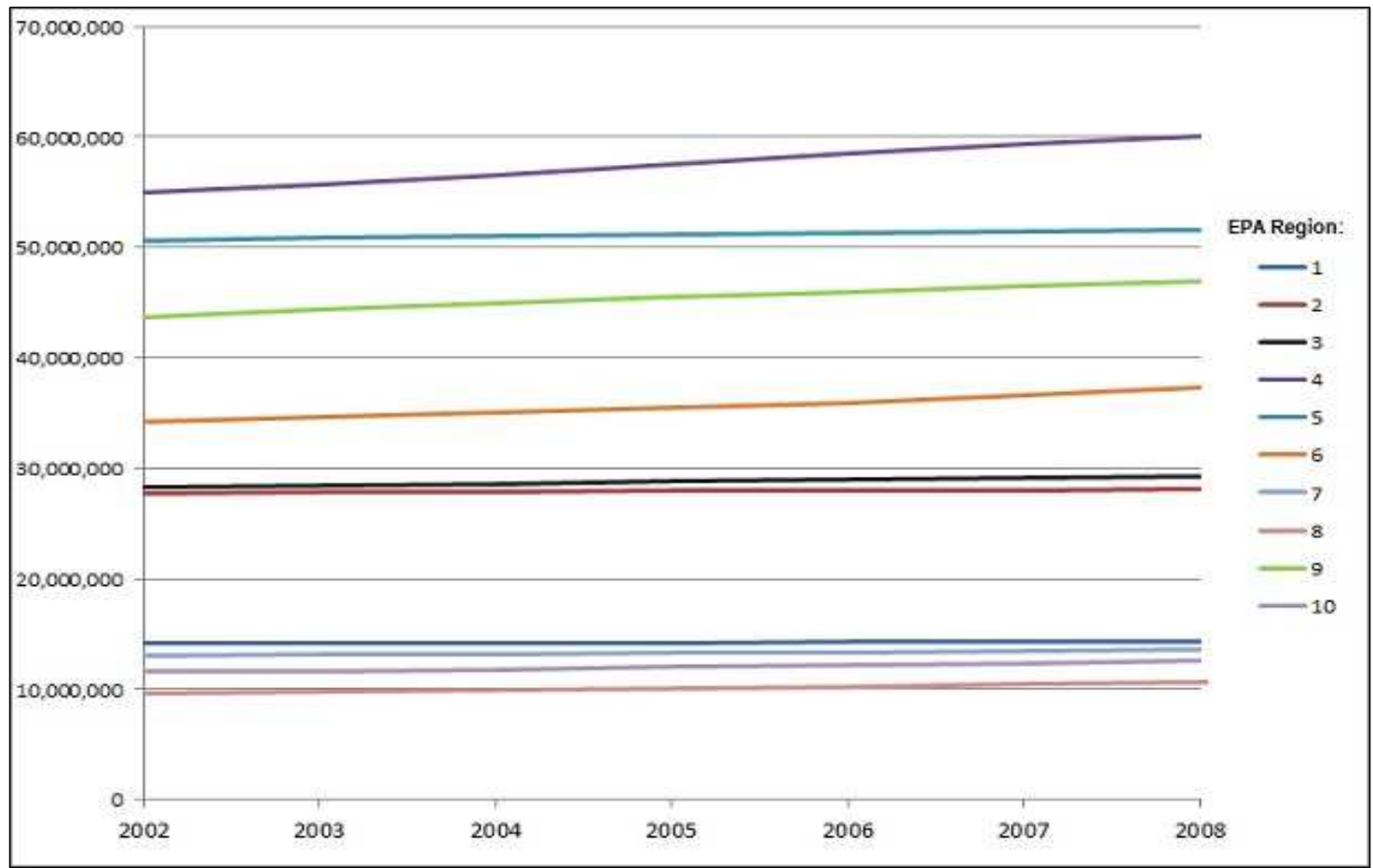

Figure 7. Population Size per EPA Region from 2002 to 2008

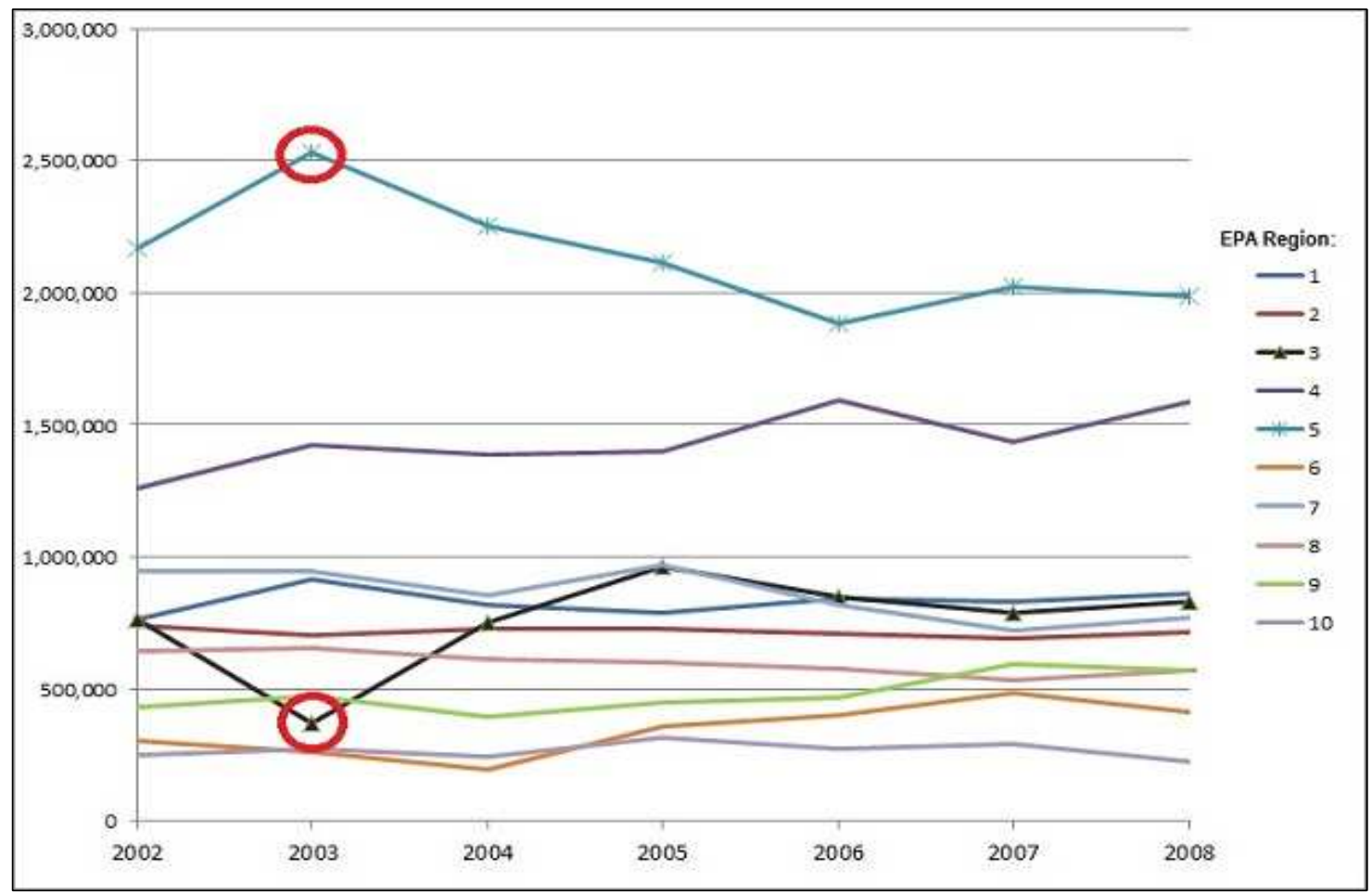

Figure 8. SIRG Funding per EPA Region from 2002 to 2008 
The population growth from 2002 to 2008 for each EPA region was very linear, as demonstrated in Figure 7. The growth in 2003 did not exhibit significant increase or decrease in population size for any of the 10 EPA regions. Therefore, the variable "Population size" was unlikely the primary contributing factor for the FY 2003 regression model to fail the significance test.

Figure 8 , however, does point out 2 very obvious outliers. These outliers are highlighted by the circles on the graph. Both outliers demonstrate a significant change in allocation of SIRG funds for FY 2003 for EPA regions 3 and 5. EPA region 3 received $\$ 392,254$ or $51 \%$ less funding in FY 2003 than the previous fiscal year, and EPA region 5 received \$360,000 more in FY 2003. Sequentially, the funding for EPA region 3 in FY 2004 increased by $\$ 381,000$ or $45 \%$, and the funding for EPA region 5 decreased by $\$ 278,000$ in FY 2004. The state-level allocation of funds needed to be examined to evaluate why the allocation of SIRG funding for EPA regions 3 and 5 was substantially different in FY 2003. This step is described in the next chapter. 


\section{Chapter 5 State-Level Analysis}

\section{Result of Assumption Tests}

Compared to the regional analysis, the state-level relationships exhibited significantly more scatter. The only meaningful strong relationship at the state-level was the relationship between the independent variable "Number of counties with zone 1 (high) radon levels" and the dependent variable "SIRG funding." The relationship between "Number of counties with zone 2 (medium) radon levels" and "SIRG funding" proved to be the least linear. If anything, it displayed either a very weak positive linear relationship or no relationship at all. Figure 9 shows the scatterplots for each independent variable with the dependent variable for FY 2002.

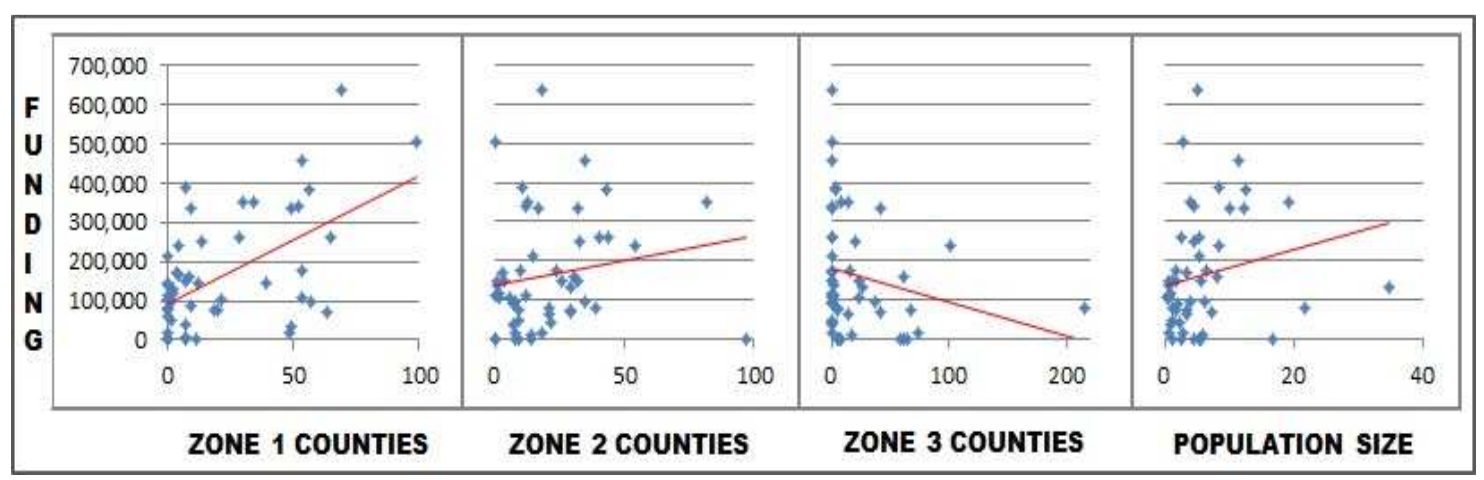

Figure 9. State-Level Scatterplots for FY 2002

The fact that several states did not participate in the SIRG program and therefore did not receive funding certainly contributed to the scatter. In FY 2002, 6 states did not participate in the program (e.g., Arkansas, Florida, Hawaii, Louisiana, Maryland, and Missouri). The relationships became significantly stronger when these states were excluded from the scatterplots (Figure 10). For example, Florida is the 4th largest populated state, yet it received no funding in FY 2002. The relationship between 
"Population size" and "SIRG funding" became stronger and the slope of the trend line was positively impacted when this state was excluded from the scatterplots. Nonetheless, the analysis needed to include these non-participating states, since this research examined the distribution of SIRG funds throughout the United States and not just the participating states. The fact that not all states participate in the SIRG program may prove to be a flaw in the EPA's funding distribution model.

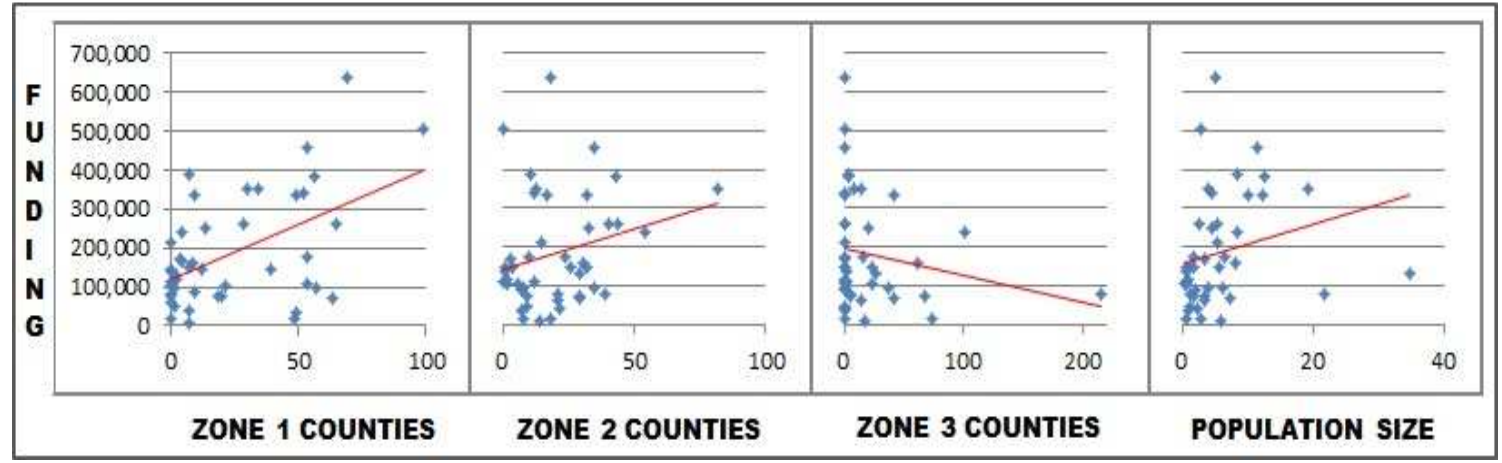

Figure 10. Scatterplots for Participating States in FY 2002

The residuals were plotted against the predicted value of the dependent variable for each fiscal year to assess the assumption of homoscedasticity. As was the case with the regional analysis, the regression models of all 7 fiscal years passed the test. Figure 11 illustrates that the data points of the plot for FY 2004 are randomly dispersed around the $\mathrm{x}$-axis and do not form any obvious pattern. The scatterplots of the other fiscal years showed very similar results. 


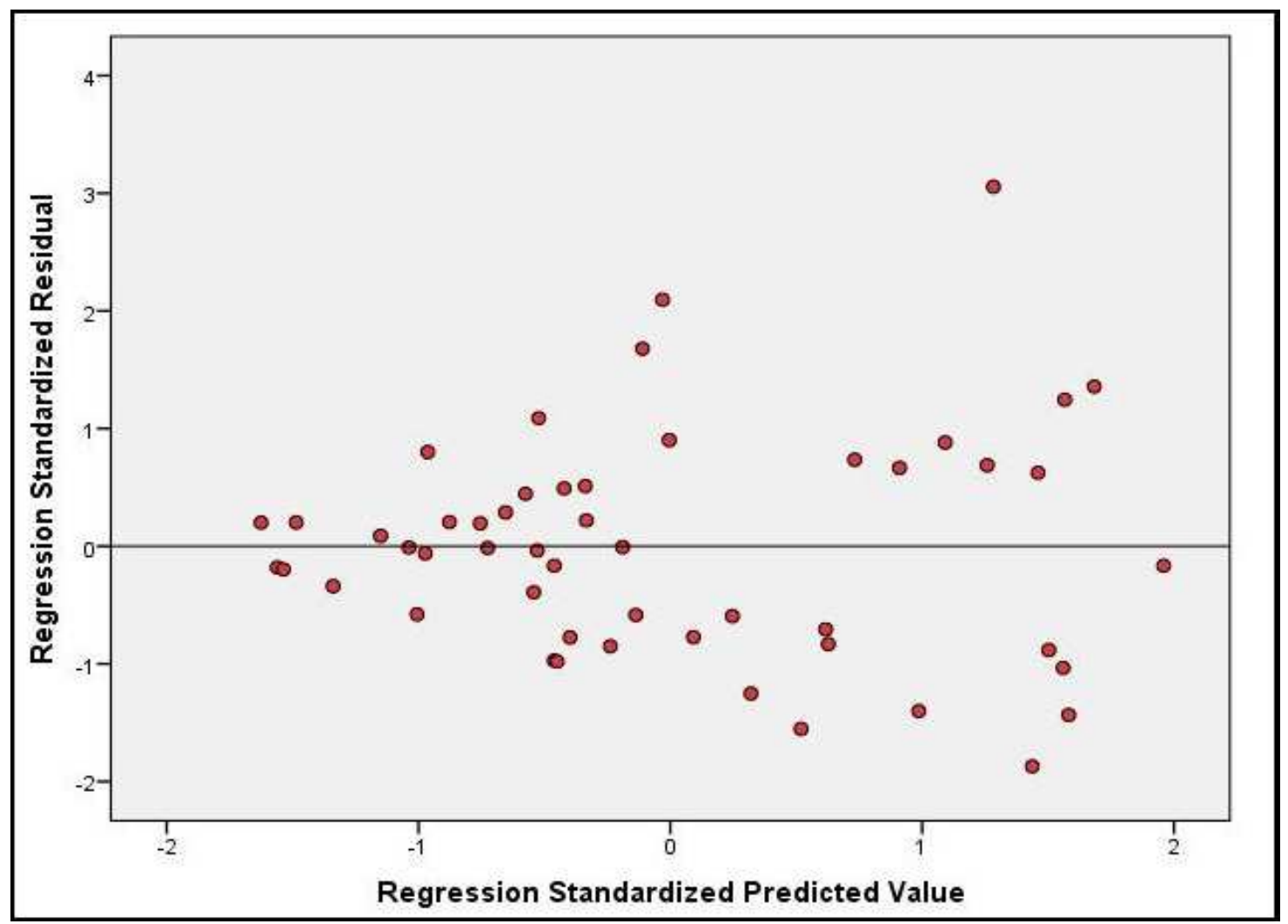

Figure 11. State-Level Residual Plot for FY 2004

The regression models for all 7 observed fiscal years passed the normality test.

Figure 12 displays the P-P plot and histogram of the residuals for FY 2006. The graphic examples of Figure 12 demonstrate that the data points of the P-P plot closely follow the diagonal line and that the shape of the histogram closely matches the shape of the normal (bell) curve. The P-P plots and histograms of the other fiscal years showed very similar results. 

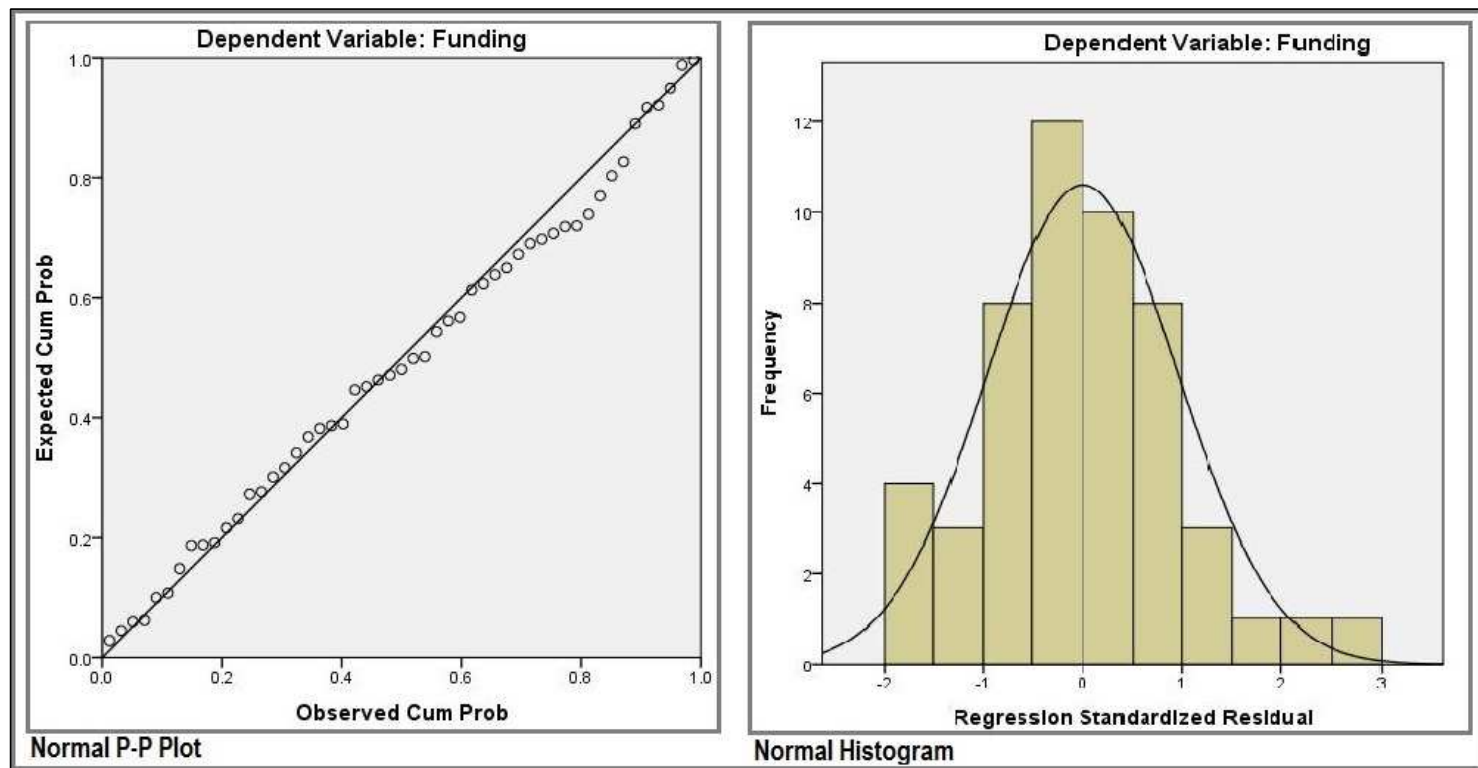

Figure 12. State-Level Normal P-P Plot and Histogram of the Residuals for FY 2006

Similar to the regional analysis, the existence of autocorrelation in any of the state-level models was highly unlikely, as each of the models related to only one fiscal year. The sample size for each model in the state analysis was 51 (e.g., 50 states and the District of Columbia), and each model included 4 explanatory variables. With $N=51$ and $k \square=4$, the Durbin-Watson table at the 5\% significance level showed $d L=1.38$ and $d U=1.72$ (Anderson et al., 1997, p. B-28). Table 9 shows the Durbin-Watson test statistics for each fiscal year. Since all test statistics were greater than $1.72(d U)$ and less than $2.28(4-d U)$, the conclusion is that no significant autocorrelation existed in any of the models.

Table 9. State-Level Durbin-Watson Test Statistics

\begin{tabular}{|c|c|c|c|c|c|c|c|}
\hline & $\mathbf{2 0 0 2}$ & $\mathbf{2 0 0 3}$ & $\mathbf{2 0 0 4}$ & $\mathbf{2 0 0 5}$ & $\mathbf{2 0 0 6}$ & $\mathbf{2 0 0 7}$ & $\mathbf{2 0 0 8}$ \\
\hline $\begin{array}{c}\text { Durbin-Watson } \\
\text { Test Statistic }\end{array}$ & 1.866 & 1.782 & 1.741 & 1.851 & 1.755 & 1.947 & 1.780 \\
\hline
\end{tabular}


The regression model for each of the fiscal years in the state-level analysis proved to be free of multicollinearity. As demonstrated in Table 10 and Table 11, the tolerance measure of each explanatory variable was consistently higher than 0.2 and the VIF values were consistently less than 10 .

Table 10. State-Level Tolerance Values

\begin{tabular}{|c|c|c|c|c|c|c|c|}
\hline & $\mathbf{2 0 0 2}$ & $\mathbf{2 0 0 3}$ & $\mathbf{2 0 0 4}$ & $\mathbf{2 0 0 5}$ & $\mathbf{2 0 0 6}$ & $\mathbf{2 0 0 7}$ & $\mathbf{2 0 0 8}$ \\
\hline $\begin{array}{c}\text { \# Zone 1 } \\
\text { Counties }\end{array}$ & 0.86 & 0.87 & 0.87 & 0.87 & 0.87 & 0.87 & 0.87 \\
\hline $\begin{array}{c}\text { \# Zone 2 } \\
\text { Counties }\end{array}$ & 0.90 & 0.90 & 0.90 & 0.90 & 0.90 & 0.90 & 0.90 \\
\hline $\begin{array}{c}\text { \# Zone 3 } \\
\text { Counties }\end{array}$ & 0.73 & 0.73 & 0.73 & 0.73 & 0.72 & 0.72 & 0.72 \\
\hline $\begin{array}{c}\text { Population } \\
\text { Size }\end{array}$ & 0.79 & 0.79 & 0.78 & 0.78 & 0.77 & 0.77 & 0.76 \\
\hline
\end{tabular}

Table 11. State-Level VIF Values

\begin{tabular}{|c|c|c|c|c|c|c|c|}
\hline & $\mathbf{2 0 0 2}$ & $\mathbf{2 0 0 3}$ & $\mathbf{2 0 0 4}$ & $\mathbf{2 0 0 5}$ & $\mathbf{2 0 0 6}$ & $\mathbf{2 0 0 7}$ & $\mathbf{2 0 0 8}$ \\
\hline $\begin{array}{c}\text { \# Zone 1 } \\
\text { Counties }\end{array}$ & 1.16 & 1.16 & 1.16 & 1.16 & 1.16 & 1.16 & 1.16 \\
\hline $\begin{array}{c}\text { \# Zone 2 } \\
\text { Counties }\end{array}$ & 1.11 & 1.11 & 1.11 & 1.11 & 1.11 & 1.11 & 1.11 \\
\hline $\begin{array}{c}\text { \# Zone 3 } \\
\text { Counties }\end{array}$ & 1.36 & 1.36 & 1.37 & 1.37 & 1.38 & 1.39 & 1.40 \\
\hline $\begin{array}{c}\text { Population } \\
\text { Size }\end{array}$ & 1.27 & 1.27 & 1.28 & 1.28 & 1.29 & 1.30 & 1.31 \\
\hline
\end{tabular}

\section{Result of Significance Tests}

The critical value of $F$ was approximately 2.58 for a $95 \%$ confidence interval (Anderson et al., 1997, p. B-6). Since all fiscal years had identical regression and error in the degrees of freedom, the critical value of $F$ could be applied to the models of all observed fiscal years. Table 12 demonstrates that the $F$ values of all fiscal years were 
greater than the critical $F$ value of 2.58 . Therefore, the conclusion is that in each fiscal year the set of independent variables was indeed related to the dependent variable.

Table 12. State-Level $F$-Values

\begin{tabular}{|c|c|c|c|c|c|c|c|}
\hline & $\mathbf{2 0 0 2}$ & $\mathbf{2 0 0 3}$ & $\mathbf{2 0 0 4}$ & $\mathbf{2 0 0 5}$ & $\mathbf{2 0 0 6}$ & $\mathbf{2 0 0 7}$ & $\mathbf{2 0 0 8}$ \\
\hline $\begin{array}{c}\boldsymbol{F} \text { - } \\
\text { value }\end{array}$ & 7.06 & 4.08 & 6.48 & 8.24 & 6.82 & 6.77 & 5.57 \\
\hline
\end{tabular}

However, a slightly different conclusion is made from the $p$-values obtained from the SPPS calculated ANOVA. The value $p$ needed to be less than 0.05 for a $95 \%$ confidence interval in order for the model to be significant. As shown in Table 13, $p$ was less than 0.05 for each fiscal year except for FY 2003. In FY 2003, $p$ was 0.07, which means the model was not significant.

Table 13. State-Level $p$-Values

\begin{tabular}{|c|c|c|c|c|c|c|c|}
\hline & $\mathbf{2 0 0 2}$ & $\mathbf{2 0 0 3}$ & $\mathbf{2 0 0 4}$ & $\mathbf{2 0 0 5}$ & $\mathbf{2 0 0 6}$ & $\mathbf{2 0 0 7}$ & $\mathbf{2 0 0 8}$ \\
\hline $\begin{array}{c}\boldsymbol{p}- \\
\text { value }\end{array}$ & 0.00 & 0.07 & 0.00 & 0.00 & 0.00 & 0.00 & 0.01 \\
\hline
\end{tabular}

The critical values of $t$ were -2.01 and 2.01 for a $95 \%$ confidence interval (Anderson et al., 1997, p. B-3). This means that each of the independent variables with a $t$-value between -2.01 and 2.01failed the $t$-test and therefore did not have a significant individual relationship with the dependent variable. Table 14 shows the $t$-values for all the independent variables of each observed fiscal year. 
Table 14. State-Level $t$-Values

\begin{tabular}{|c|c|c|c|c|c|c|c|}
\hline & $\mathbf{2 0 0 2}$ & $\mathbf{2 0 0 3}$ & $\mathbf{2 0 0 4}$ & $\mathbf{2 0 0 5}$ & $\mathbf{2 0 0 6}$ & $\mathbf{2 0 0 7}$ & $\mathbf{2 0 0 8}$ \\
\hline $\begin{array}{c}\text { \# Zone 1 } \\
\text { Counties }\end{array}$ & 3.99 & 2.45 & 2.75 & 3.06 & 2.13 & 2.19 & 1.96 \\
\hline $\begin{array}{c}\text { \# Zone 2 } \\
\text { Counties }\end{array}$ & 0.48 & 1.57 & 2.00 & 1.98 & 1.81 & 1.79 & 2.00 \\
\hline $\begin{array}{c}\text { \# Zone3 } \\
\text { Counties }\end{array}$ & -1.37 & -1.50 & -2.09 & -2.58 & -2.69 & -2.02 & -1.84 \\
\hline $\begin{array}{c}\text { Population } \\
\text { Size }\end{array}$ & 2.08 & 0.98 & 1.88 & 2.35 & 2.88 & 3.24 & 2.61 \\
\hline
\end{tabular}

The individual relationship between "SIRG funding" and "Number of counties with zone 2 (medium) radon levels" proved never to be significant, since the $t$-values were consistently between -2.01 and 2.01. However, the individual relationship between "SIRG funding" and "Number of counties with zone 1 (high) radon levels" proved to be significant for 6 out of 7 fiscal years. The exception was FY 2008, since the $t$-value was 1.96, which is between -2.01 and 2.01 .

Based on the significance test results obtained from the $F$-test and the $t$-test, the conclusion is that the independent variables were related to the dependent variable collectively but not necessarily individually. Thus, the model was significant, but only some of the individual relationships between the dependent and the independent variables were significant. The exception was FY 2003, because this was the only fiscal year in which the model was not statistically significant, since $p$ was greater than 0.05 .

\section{Interpreting the Model}

Table 15 shows the partial regression coefficients of the regression models for each observed fiscal year. These coefficients were obtained from the individual 
coefficient tables in SPPS. Even though the $t$-test revealed that some of the individual relationships between the dependent variable and the independent variables were not statistically significant, these coefficients were still useful to further interpret each of the regression models.

Table 15. State-Level Partial Regression Coefficients

\begin{tabular}{|c|c|c|c|c|c|c|c|}
\hline & $\mathbf{2 0 0 2}$ & $\mathbf{2 0 0 3}$ & $\mathbf{2 0 0 4}$ & $\mathbf{2 0 0 5}$ & $\mathbf{2 0 0 6}$ & $\mathbf{2 0 0 7}$ & $\mathbf{2 0 0 8}$ \\
\hline Constant & 71,570 & 79,940 & 70,502 & 74,239 & 84,779 & 76,207 & 79,944 \\
\hline $\begin{array}{c}\text { \# Zone 1 } \\
\text { Counties }\end{array}$ & 2,914 & 2,356 & 2,067 & 2,244 & 1,451 & 1,407 & 1,357 \\
\hline $\begin{array}{c}\text { \# Zone 2 } \\
\text { Counties }\end{array}$ & 439 & 1,876 & 1,883 & 1,812 & 1,539 & 1,437 & 1,732 \\
\hline $\begin{array}{c}\text { \# Zone3 } \\
\text { Counties }\end{array}$ & -732 & $-1,061$ & $-1,156$ & $-1,396$ & $-1,355$ & -961 & -945 \\
\hline $\begin{array}{c}\text { Population } \\
\text { Size }\end{array}$ & .006 & .004 & .006 & .007 & .008 & .008 & .007 \\
\hline
\end{tabular}

The regression models for each of the fiscal years were derived from the data in

Table 15. The following is an example of the regression model for FY 2008:

$$
Y=79,944+1,357 x_{1}+1,732 x_{2}-945 x_{3}+0.007 x_{4}
$$

Where,

$-\mathrm{Y}=$ SIRG funding

$-\mathrm{x}_{1}=\quad$ Number of counties with zone 1 (high) radon levels

$-\mathrm{x}_{2}=$ Number of counties with zone 2 (medium) radon levels

$-\mathrm{x}_{3}=\quad$ Number of counties with zone 3 (low) radon levels

$-\mathrm{x}_{4}=$ Population size

For FY 2008, the model can be interpreted as follows:

- A constant $(\alpha)$ of 79,944 means that if all of the independent variables are equal to zero, then the variable "SIRG funding" (Y) will increase by $\$ 79,944$. 
- If all other independent variables remain constant or are equal to zero, an increase of one unit in the variable "Number of counties with zone 1 (high) radon levels" $\left(\mathrm{x}_{1}\right)$ will result in an average increase of $\$ 1,357$ in "SIRG funding" (Y).

- If all other independent variables remain constant or are equal to zero, an increase of one unit in the variable "Number of counties with zone 2 (medium) radon levels" $\left(\mathrm{x}_{2}\right)$ will result in an average increase of $\$ 1,732$ in "SIRG funding" (Y).

- If all other independent variables remain constant or are equal to zero, an increase of one unit in the variable "Number of counties with zone 3 (low) radon levels" $\left(\mathrm{x}_{3}\right)$ will result in an average decrease of $\$ 945$ in "SIRG funding" (Y).

- If all other independent variables remain constant or are equal to zero, an increase of one unit in the variable "Population size" $\left(\mathrm{x}_{4}\right)$ will result in an average increase of $\$ 0.007$ in "SIRG funding" $(\mathrm{Y})$.

Table 16 shows the coefficient of determination $\left(R^{2}\right)$ values, calculated in SPSS, for all 7 observed fiscal years. The coefficient of determination explains the total variation in the dependent variable caused by all the independent variables combined. As shown in Table 16 , the $R^{2}$ value for FY 2002 was 0.38 . This means that $38 \%$ of the variation in the dependent variable "SIRG funding" was caused by the independent variables "Number of counties with zone 1 (high) radon levels," "Number of counties with zone 2 (medium) radon levels," "Number of counties with zone 3 (medium) radon levels," and "Population size." The remaining $62 \%$ of the variation in "SIRG funding" is caused by factors that weren't represented in the model. The models for the other fiscal years showed similar results. FY 2005 had the highest coefficient of determination with $R^{2}=0.42$ and FY 2008 had the lowest coefficient of determination with $R^{2}=0.33$. The coefficient of determination for FY 2003 was ignored, since the model for FY 2003 was not statistically significant. 
Table 16. State-Level Coefficients of Determination $\left(R^{2}\right)$

\begin{tabular}{|c|c|c|c|c|c|c|c|}
\hline & $\mathbf{2 0 0 2}$ & $\mathbf{2 0 0 3}$ & $\mathbf{2 0 0 4}$ & $\mathbf{2 0 0 5}$ & $\mathbf{2 0 0 6}$ & $\mathbf{2 0 0 7}$ & $\mathbf{2 0 0 8}$ \\
\hline $\boldsymbol{p}$ & 0 & 0.07 & 0 & 0 & 0 & 0 & 0.01 \\
\hline $\boldsymbol{R}^{2}$ & 0.38 & 0.26 & 0.36 & 0.42 & 0.37 & 0.37 & 0.33 \\
\hline
\end{tabular}

\section{Discussion}

Individually, some of the independent variables proved to have a significant relationship with the dependent variable "SIRG funding." The independent variable "Number of counties with zone 1 (high) radon levels" showed a significant positive effect on the level of funding in 6 of the 7 models, the independent variable "Population size" demonstrated a significant positive effect in 5 of the 7 models, and the independent variable "Number of counties with zone 3 (low) radon levels" showed a significant negative effect on the level of funding in 4 of the 7 models. However, the variable "Number of counties with zone 2 (medium) radon levels" never proved to have a significant impact on "SIRG funding." It failed the $t$-test in each observed fiscal year. In other words, an increase in the number of high level radon counties or an increase in population would likely increase the level of funding, whereas an increase in the number of low level radon counties would likely decrease the level of funding. A change in the number of medium level radon counties would likely not have a significant impact on the level of funding at all.

The combined effect of these independent variables at the state-level allocation of SIRG funds proved to be significant for 6 out of 7 models. Similar to the regional analysis, the model for FY 2003 was not significant. Even though 6 out of 7 models

proved to be significant, the combined effect on "SIRG funding" was relatively low. The 
coefficients of determination for the significant models were between 0.33 and 0.42 , which means that in each fiscal year more than $50 \%$ of the variation in "SIRG funding" was attributed to other factors.

This research examined the effect of county radon levels and population size on the EPA's allocation of SIRG funds. A determination of what other factors could possibly influence the level of SIRG funding was not the objective of this research. However, the fact that the state allocation of funds requires matching funds and the regional allocation does not require any matching seems a very plausible explanation for the large discrepancies in the coefficients of determination between the 2 analyses.

Many states have difficulty fulfilling the $40 \%$ matching requirement of the SIRG funds. As a result, states with relatively high radon levels may receive proportionally low or no SIRG funding at all (Scheberle, 2004). For example, the State of Indiana has 57 high radon level counties and the State of Delaware has no high radon level counties at all. Furthermore, Indiana has over 6 times the population of Delaware. Yet, in each of the observed fiscal years, Delaware received more SIRG funding than Indiana. Scheberle (2004) continued to explain that radon fails to capture the attention of state legislators or congress, in large part because radon fails to command much public attention. As a result, radon is not a high priority budget item for most states. Scheberle (2004) also conducted interviews with several state radon coordinators, who confirmed that the matching requirement made it hard for various states to acquire sufficient SIRG funds.

This matching requirement may also explain why the model for FY 2003 in both the regional as well as the state-level analysis proved to be statistically insignificant. As 
pointed out in the regional analysis, EPA region 3 received significantly less funding in FY 2003 compared to the other fiscal years. The funding declined by $\$ 392,254$ or $51 \%$ compared to FY 2002 and then increased again by $\$ 381,000$ or $45 \%$ in FY 2004. Figure 13 shows the state allocation of funds for EPA region 3 for the observed fiscal years. The graph clearly illustrates that the State of Pennsylvania was the primary cause of region 3's decline in funding for FY 2003. It received \$340,000 in FY2002, then nothing in FY 2003, and then \$360,000 in FY 2004.

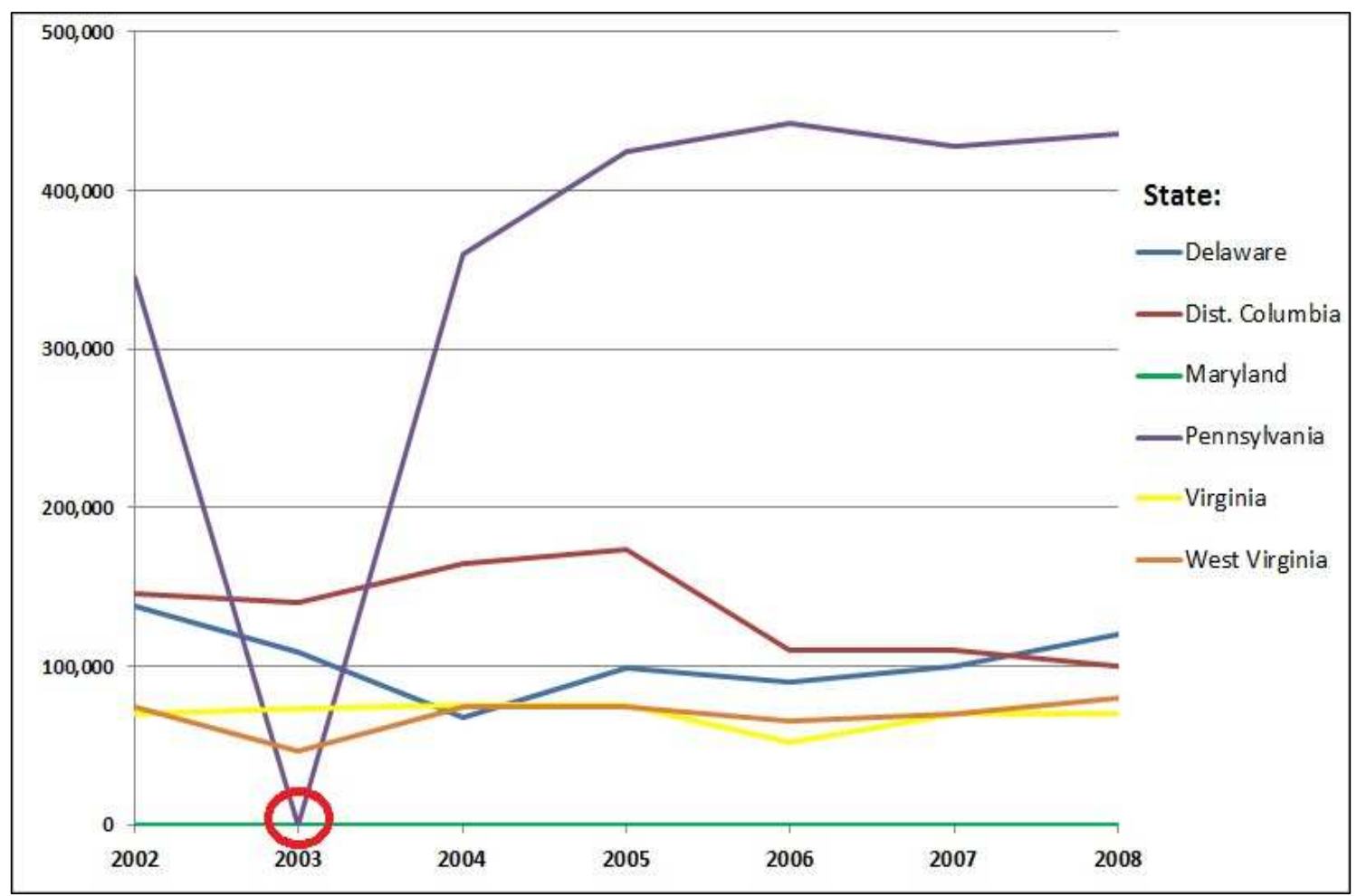

Figure 13. State SIRG Funding for EPA Region 3

The State of Pennsylvania faced a severe budget crisis in 2003. As a result the funding for environmental protection programs in Pennsylvania decreased from approximately \$246 million in FY 2002/2003 to approximately \$179 million in FY $2003 / 2004$, which corresponds to a budget cut for environmental programs of over $27 \%$ 
(Rendell, 2003). Likely, the $40 \%$ matching requirement of the SIRG program was part of these budget cuts.

As indicated at the beginning of this chapter, several other states (e.g., Arkansas, Florida, Hawaii, Louisiana, Maryland, Missouri, and Texas) also did not participate in the SIRG program during one or more of the observed fiscal years. For states such as Hawaii and Louisiana this is somewhat understandable, since neither state has any high or even medium level radon counties. However, states such as Maryland and Missouri have respectively 7 and 11 high level radon counties and respectively 8 and 97 medium level radon counties. Yet, Missouri did not participate in FY 2002 and Maryland never participated in the SIRG program during the observed fiscal years.

The Tables 17 and 18 show the SIRG funding per state for FY 2002. Table 17 shows the actual SIRG funding per state and Table 18 shows the funding each state was predicted to receive per the regression model for FY 2002 (e.g., Y $=71,570+2,914 \mathrm{x}_{1}+$ $439 \mathrm{x}_{2}-732 \mathrm{x}_{3}+0.006 \mathrm{x}_{4}$ ). When the FY 2002 regression model is applied to Maryland and Missouri, Table 18 indicates that these states were predicted to receive respectively $\$ 121,275$ and $\$ 175,168$ in SIRG funding for FY 2002, yet in actuality they both received nothing in FY 2002. The predicted funding amounts move Maryland from rank 46 to 29 and Missouri from rank 46 to 19 in SIRG funds received for FY 2002. 
Table 17. State SIRG Funding in FY 2002

\begin{tabular}{|c|c|c|c|c|c|c|c|c|}
\hline Rank & State & Funding & Rank & State & Funding & Rank & State & Funding \\
\hline 1 & Minnesota & 638,176 & 18 & Connecticut & 168,308 & \begin{tabular}{|l|l}
35 & 1 \\
\end{tabular} & Idaho & 76,960 \\
\hline 2 & lowa & 505,801 & 19 & North Carolina & 159,901 & 36 & Oklahoma & 75,528 \\
\hline 3 & Ohio & 458,260 & 20 & New Mexico & 150,186 & 37 & West Virginia & 75,000 \\
\hline 4 & New Jersey & 390,000 & 21 & Maine & 147,333 & 38 & Virginia & 69,532 \\
\hline 5 & Illinois & 381,465 & 22 & Tennessee & 146,041 & 39 & Oregon & 62,320 \\
\hline 6 & New York & 351,615 & 23 & District of Columbia & 145,718 & 40 & New Hampshire & 48,554 \\
\hline 7 & Kentucky & 349,337 & 24 & Delaware & 138,525 & 41 & Utah & 40,500 \\
\hline 8 & Colorado & 340,000 & 25 & California & 130,000 & 42 & Montana & 34,500 \\
\hline 9 & Pennsylvania & 339,700 & 26 & Rhode Island & 117,008 & 43 & Mississippi & 16,912 \\
\hline 10 & Michigan & 334,976 & 27 & Vermont & 111,773 & 44 & South Dakota & 15,500 \\
\hline 11 & Kansas & 262,070 & 28 & North Dakota & 110,000 & 45 & Washington & 7,500 \\
\hline 12 & Wisconsin & 261,123 & 29 & Wyoming & 105,000 & 46 & Arkansas & 0 \\
\hline 13 & Alabama & 248,966 & 30 & Alaska & 104,843 & 46 & Florida & 0 \\
\hline 14 & Georgia & 240,246 & 31 & Indiana & 96,325 & 46 & Hawaii & 0 \\
\hline 15 & Arizona & 212,709 & 32 & South Carolina & 96,244 & 46 & Louisiana & 0 \\
\hline 16 & Nebraska & 175,320 & 33 & Nevada & 88,633 & 46 & Maryland & 0 \\
\hline 17 & Massachusetts & 173,168 & 34 & Texas & 80,465 & 46 & Missouri & 0 \\
\hline
\end{tabular}

Table 18. State SIRG Funding per FY 2002 Regression Model

\begin{tabular}{|c|c|c|c|c|c|c|c|c|}
\hline Rank & State & Funding & Rank & State & Funding & Rank & State & Funding \\
\hline 1 & lowa & 377,632 & 18 & Wisconsin & 205,159 & 35 & New Mexico & 110,868 \\
\hline 2 & Illinois & 326,784 & 19 & Missouri & 175,168 & 36 & Connecticut & 104,501 \\
\hline 3 & Minnesota & 310,643 & 20 & West Virginia & 148,985 & 37 & Oregon & 90,912 \\
\hline 4 & Ohio & 309,903 & 21 & New Jersey & 145,866 & 38 & Georgia & 86,062 \\
\hline 5 & Pennsylvania & 295,045 & 22 & Florida & 141,333 & 39 & New Hampshire & 84,513 \\
\hline 6 & Kansas & 294,816 & 23 & Michigan & 137,634 & 40 & Rhode Island & 83,940 \\
\hline 7 & Indiana & 289,927 & 24 & Idaho & 136,624 & 41 & Vermont & 79,064 \\
\hline 8 & California & 280,840 & 25 & Wyoming & 135,402 & 42 & South Carolina & 75,536 \\
\hline 9 & Virginia & 280,344 & 26 & Alabama & 133,147 & 43 & Delaware & 75,487 \\
\hline 10 & New York & 279,622 & 27 & Washington & 122,616 & 44 & Hawaii & 75,370 \\
\hline 11 & Colorado & 255,392 & 28 & Massachusetts & 121,531 & 45 & District of Columbia & 75,278 \\
\hline 12 & Nebraska & 235,186 & 29 & Maryland & 121,275 & 46 & Texas & 61,576 \\
\hline 13 & North Dakota & 229,814 & 30 & Utah & 116,058 & 47 & Alaska & 61,224 \\
\hline 14 & South Dakota & 223,917 & 31 & North Carolina & 115,633 & 48 & Louisiana & 51,518 \\
\hline 15 & Montana & 222,888 & 32 & Maine & 114,482 & 49 & Arkansas & 49,292 \\
\hline 16 & Tennessee & 216,516 & 33 & Arizona & 113,739 & 50 & Oklahoma & 46,654 \\
\hline 17 & Kentucky & 213,680 & 34 & Nevada & 113,134 & 51 & Mississippi & 38,066 \\
\hline
\end{tabular}


Other interesting observations in the ranking difference between the 2 tables relate to the States of New Jersey and South Dakota. New Jersey received $\$ 390,000$ in FY 2002, which was the 4th largest funding amount that year. Yet, according to the regression model for FY 2002, it was predicted to receive $\$ 145,866$, which was the 21st largest funding amount. South Dakota, however, only received \$15,500 in FY 2002, which was one of the lowest funding amounts that year. Yet, according to the regression model, it was predicted to receive $\$ 223,917$, which was the 14 th largest funding amount in that fiscal year. Interestingly, Scheberle (2004) also emphasized the low SIRG funding amount for South Dakota. She stated that while South Dakota is ranked highest of all states in terms of radon concentration per unit of livable space, it only received $\$ 18,500$ in FY 2003, which was one of the lowest state funding amounts in that fiscal year. 


\section{Chapter 6 Conclusion}

The objective of this research was to examine whether the SIRG program

effectively targets states with the highest radon levels and largest populations. Consistent with the EPA's allocation of SIRG funds, the analysis was divided into a regional and a state-level analysis. In both analyses, 6 out of 7 regression models were statistically significant. The regression model for FY 2003 was the only model that was not statistically significant in the regional, as well as the state-level analysis. Research indicated that this insignificance was caused by the State of Pennsylvania, which had a ripple effect on EPA region 3. Pennsylvania is a top recipient of SIRG funding, but in FY 2003 the state received no SIRG funding at all. Likely the state could not afford the $40 \%$ matching requirement due to the budget crisis it faced in FY 2003/2004.

Based on the relatively high coefficients of determination of the 6 significant regional regression models, the conclusion is that the regional allocation of funds was indeed primarily related to a combination of county radon levels and population size. All of the coefficients of determination were higher than 0.8 , which means that less than $20 \%$ of the variation in regional SIRG funding was attributed to other factors. According to the EPA, but not addressed in this research, these other factors are smoking rates, and a state's success in previous years of the SIRG program.

The state-level analysis showed a significantly different picture. Based on the relatively low coefficients of determination of the 6 significant state-level regression models, the conclusion is that the state allocation of funds was only marginally related to a combination of county radon levels and population size. The coefficients of 
determination for the significant state-level models were between 0.33 and 0.42 , which means that in each fiscal year more than half of the variation in SIRG funding was attributed to other factors. The EPA acknowledges that its funding allocation models are only applied to the regional allocation and not to the state-level allocation. This research substantiated that the impact of county radon levels and population size on SIRG funding was significantly higher in the regional allocation than in the state-level allocation.

A likely explanation of why the EPA does not apply its regional allocation model to the state-level allocation of funds is that the state-level funding includes a matching requirement of at least $40 \%$ and the regional funding does not require any matching. This matching requirement causes difficulty for the SIRG program to meet its objective of targeting resources to the greatest risk areas and populations. States with relatively high radon levels and large populations may not be able to afford this matching requirement, and thus end up receiving less funding than states with relatively low radon levels and small populations.

Furthermore, states may have other pressing environmental issues as well, such as floods, earthquakes, or hurricanes, which generally attract much more public attention than radon. Most legislators are unlikely to make radon a high priority budget item, as long as radon fails to command much public attention. The State of Pennsylvania was facing a severe budget crisis in 2003, which resulted in more than $27 \%$ budget cuts for environmental protection programs. Consequently, Pennsylvania's SIRG program was completely canceled that year. On a similar note, the President's proposal to eliminate 
funding for the SIRG program altogether in FY 2013 is a direct result of the current federal budget crisis.

Based on the combined results of the regional and state-level analysis, the conclusion is that the SIRG program is only marginally effective in its ability to target funds to states with the highest radon levels and largest populations. The regional allocation of funds is primarily related to a combination of county radon levels and population size, while the state-level allocation of funds is only partially related to these variables. The state allocation of funds is too dependent on the ability and willingness of state legislators to fulfill the $40 \%$ minimum matching requirement. As a result, various states do not receive a funding amount that matches their radon risk potential.

The matching requirement needs to be addressed in order to make the state-level allocation of SIRG funds more dependent on county radon levels and population size. Ideally, the matching requirement would be canceled altogether, which would enable the EPA to apply the same funding allocation model that works rather well at the regional level, to the state-level allocation of SIRG funds. Naturally, the downside of eliminating the matching requirement is that the funding would decrease by a minimum of $40 \%$. 


\section{References}

Anderson, D. R., Sweeney, D. J., Williams, T. A. (1996). Statistics for Business and Economics (6th ed.). St Paul, MN: West Publishing Company.

Christensen, L. G., Rigby, J. G. (1995). GIS Applications to Radon Hazard Studies - An Example from Nevada. Retrieved June, 2012, from http://www.nbmg.unr.edu/ dox/radon/index.html

Devore, J. L. (1995). Probability and Statistics for Engineering and the Sciences (4th ed.). Belmont, CA: Duxbury Press.

Levine, D. M., Stephan, D., Berenson, M.L. (1997). Statistics for Managers Using Microsoft Excel. Upper Saddle River, NJ: Prentice Hall.

Marcinowski, F. (1995). EPA's Strategy to Reduce Risk of Radon. Retrieved October, 2011, from http://www.aarst.org/proceedings/1995/1995_02_epas_strategy_to_ reduce_risk_of_radon.pdf

National Research Council. (1999). Health Effect of Exposure to Radon: BEIR VI. Washington D.C.: National Academy Press.

Nielson, K. K., Holt, R. B., Rogers, V. C. (1995). Statewide Mapping of Florida Soil Radon Potentials (Publication Number EPA-600-SR-95-142). Retrieved April, 2006, from http://cfpub.epa.gov/ols/catalog/catalog_brief_record.cfm

Price, P. N., Nero, A. N., Boscardin, W. J. (1993). High Radon Project, Lawrence BerkeleyNational Laboratory Report LBL-34263. Retrieved April, 2006, from http://eetd. lbl.gov/IEP/high-radon/files.html

Rendell, E. G. (2003). Commonwealth of Pennsylvania 2003-04 Budget in Brief. Retrieved June, 2012, from http://www.state.pa.us/

Scheberle, D. (2004). Federalism and Environmental Policy: Trust and the Politics of Implementation. Washington D.C.: Georgetown University Press.

SPSS Inc. (2011). IBM SPSS Statistics (Version 20.0.0.1) [Computer Software]. Armonk, NY: IBM Corporation. 
U.S. Census Bureau. (2010). Annual Estimates of the Resident Population for Counties: April 1,2000 to July 1, 2009 [Data File]. Retrieved November, 2011, from http:// www.census.gov/popest/data/counties/totals/2009/CO-EST2009-01.html

U.S. Environmental Protection Agency. (2004a). EPA Map of Radon Zones [Data File]. Retrieved March, 2006, from http://www.epa.gov/radon/zonemap.html

U.S. Environmental Protection Agency. (2004b). EPA Map of Radon Zones Document (Publication Number EPA-402-R-93-071). Retrieved March, 2006, from http:// www.epa.gov/radon/zonemap/document.html

U.S. Environmental Protection Agency. (2005). State and Tribal Indoor Radon Grants Program Guidance and Handbook. Retrieved October, 2011, from http://www. epa.gov/radon/pdfs/guidance_and_handbook.pdf

U.S. Environmental Protection Agency. (2011). Grants Award Database, State Indoor Radon Grants [Data File]. Retrieved November, 2011, from http://yosemite.epa. gov/oarm/igms_egf.nsf/homepage?readform

U.S. Environmental Protection Agency. (2012a). A Citizen's Guide to Radon: The Guide to Protecting Yourself and Your Family from Radon. Retrieved February, 2012, from http://www.epa.gov/radon/pdfs/guidance_and_handbook.pdf

U.S. Environmental Protection Agency. (2012b). FY 2013 EPA Budget in Brief, (Publication Number EPA-190-S-12-001). Retrieved February, 2012, from http:// www.nepis.epa.gov/exe/zypurl.cgi?dockey=p100drb5.txt 


\section{Appendix 1 Regional SPSS Outputs}

Fiscal Year 2002

Descriptive Statistics

\begin{tabular}{|l|r|r|r|}
\hline & \multicolumn{1}{|c|}{ Mean } & Std. Deviation & $\mathrm{N}$ \\
\hline Funding & 827634.09 & 558807.725 & 10 \\
Population & 28780391.40 & 16797795.119 & 10 \\
Zone1_Counties & 107.00 & 103.109 & 10 \\
Zone2_Counties & 103.60 & 78.032 & 10 \\
Zone3_Counties & 103.70 & 155.526 & 10 \\
\hline
\end{tabular}

\begin{tabular}{|c|c|c|c|c|c|}
\hline & & Funding & Population & Zone1_Counties & Zone2_Counties \\
\hline & Funding & 1.000 & .526 & .683 & .724 \\
\hline & Population & .526 & 1.000 & -.015 & .598 \\
\hline $\begin{array}{l}\text { Pearson } \\
\text { Correlation }\end{array}$ & Zone1_Counties & .683 & -.015 & 1.000 & .511 \\
\hline & Zone2_Counties & .724 & .598 & .511 & 1.000 \\
\hline & Zone3_Counties & -.049 & .518 & -.298 & .470 \\
\hline & Funding & & .059 & .015 & .009 \\
\hline & Population & .059 & & .484 & .034 \\
\hline Sig. (1-tailed) & Zone1_Counties & .015 & .484 & & .066 \\
\hline & Zone2_Counties & .009 & .034 & .066 & \\
\hline & Zone3_Counties & .446 & .062 & 201 & .085 \\
\hline & Funding & 10 & 10 & 10 & 10 \\
\hline & Population & 10 & 10 & 10 & 10 \\
\hline $\mathrm{N}$ & Zone1_Counties & 10 & 10 & 10 & 10 \\
\hline & Zone2_Counties & 10 & 10 & 10 & 10 \\
\hline & Zone3_Counties & 10 & 10 & 10 & 10 \\
\hline
\end{tabular}




\section{Correlations}

\begin{tabular}{|c|c|c|}
\hline & & Zone3_Counties \\
\hline & Funding & -.049 \\
\hline & Population & .518 \\
\hline Pearson Correlation & Zone1_Counties & -.298 \\
\hline & Zone2_Counties & .470 \\
\hline & Zone3_Counties & 1.000 \\
\hline & Funding & .446 \\
\hline & Population & .062 \\
\hline Sig. (1-tailed) & Zone1_Counties & .201 \\
\hline & Zone2_Counties & .085 \\
\hline & Zone3_Counties & \\
\hline & Funding & 10 \\
\hline & Population & 10 \\
\hline $\mathrm{N}$ & Zone1_Counties & 10 \\
\hline & Zone2_Counties & 10 \\
\hline & Zone3_Counties & 10 \\
\hline
\end{tabular}

\section{Variables Entered/Removed $^{\mathrm{a}}$}

\begin{tabular}{|l|l|l|l|}
\hline Model & \multicolumn{1}{|c|}{$\begin{array}{c}\text { Variables } \\
\text { Entered }\end{array}$} & $\begin{array}{c}\text { Variables } \\
\text { Removed }\end{array}$ & Method \\
\hline 1 & $\begin{array}{l}\text { Zone3_Counties } \\
\text { Zone1_Counties } \\
\text { Population, } \\
\text { Zone2_Counties } \\
\mathrm{b}\end{array}$ & & \\
& & Enter \\
\hline
\end{tabular}

a. Dependent Variable: Funding

b. All requested variables entered. 
Model Summary

\begin{tabular}{|c|c|c|c|c|c|c|c|}
\hline \multirow[t]{2}{*}{ Model } & \multirow[t]{2}{*}{$\mathrm{R}$} & \multirow[t]{2}{*}{ R Square } & \multirow{2}{*}{$\begin{array}{l}\text { Adjusted R } \\
\text { Square }\end{array}$} & \multirow{2}{*}{$\begin{array}{l}\text { Std. Error of the } \\
\text { Estimate }\end{array}$} & \multicolumn{3}{|c|}{ Change Statistics } \\
\hline & & & & & $\begin{array}{c}\text { R Square } \\
\text { Change }\end{array}$ & $\begin{array}{c}\mathrm{F} \\
\text { Change }\end{array}$ & df1 \\
\hline 1 & $.911^{\mathrm{a}}$ & .830 & .694 & 309318.455 & .830 & 6.093 & 4 \\
\hline
\end{tabular}

Model Summary ${ }^{\mathrm{b}}$

\begin{tabular}{|l|r|rr|}
\hline \multirow{2}{*}{ Model } & \multicolumn{3}{|c|}{ Change Statistics } \\
\cline { 2 - 4 } & \multicolumn{2}{|c|}{ df2 Sig. F Change } \\
\hline 1 & & $5^{\text {a }}$ & .037 \\
\hline
\end{tabular}

a. Predictors: (Constant), Zone3_Counties, Zone1_Counties, Population, Zone2_Counties

b. Dependent Variable: Funding

ANOVA $^{\mathrm{a}}$

\begin{tabular}{|c|c|c|c|c|c|}
\hline Model & Sum of Squares & df & Mean Square & $\mathrm{F}$ & Sig. \\
\hline $\begin{array}{l}\text { Regression } \\
\text { Residual } \\
\text { Total }\end{array}$ & $\begin{array}{r}2332005129200 \\
.568 \\
\\
478389532218 . \\
375 \\
\\
2810394661418 \\
.943\end{array}$ & $\begin{array}{l}5 \\
9\end{array}$ & $\begin{array}{r}583001282300 \\
142 \\
95677906443.6 \\
75\end{array}$ & 6.093 & $.037^{b}$ \\
\hline
\end{tabular}

a. Dependent Variable: Funding

b. Predictors: (Constant), Zone3_Counties, Zone1_Counties, Population, Zone2_Counties 
Coefficients $^{\mathrm{a}}$

\begin{tabular}{|c|c|c|c|c|c|c|}
\hline \multirow{2}{*}{\multicolumn{2}{|c|}{ Model }} & \multicolumn{2}{|c|}{ Unstandardized Coefficients } & \multirow{2}{*}{$\begin{array}{c}\text { Standardized } \\
\text { Coefficients }\end{array}$} & \multirow[t]{2}{*}{$\mathrm{t}$} & \multirow[t]{2}{*}{ Sig. } \\
\hline & & $B$ & Std. Error & & & \\
\hline \multirow{5}{*}{1} & (Constant) & 2191.246 & 238768.913 & & .009 & .993 \\
\hline & Population & .015 & .009 & .458 & 1.761 & 139 \\
\hline & Zone1_Counties & 1703.407 & 1759.171 & 314 & 968 & 377 \\
\hline & Zone2_Counties & 3496.574 & 2804.798 & 488 & 1.247 & 268 \\
\hline & Zone3_Counties & -1518.039 & 1067.314 & -.422 & -1.422 & .214 \\
\hline
\end{tabular}

\begin{tabular}{|c|c|c|c|c|c|c|}
\hline \multirow{2}{*}{\multicolumn{2}{|c|}{ Model }} & \multicolumn{3}{|c|}{ Correlations } & \multicolumn{2}{|c|}{ Collinearity Statistics } \\
\hline & & Zero-order & Partial & Part & Tolerance & VIF \\
\hline \multirow{5}{*}{1} & (Constant) & & & & & \\
\hline & Population & .526 & 619 & .325 & .503 & 1.986 \\
\hline & Zone1_Counties & .683 & .397 & 179 & .323 & 3.095 \\
\hline & Zone2_Counties & .724 & .487 & .230 & .222 & 4.506 \\
\hline & Zone3_Counties & -.049 & -.537 & -.262 & .386 & 2.592 \\
\hline
\end{tabular}

a. Dependent Variable: Funding

Collinearity Diagnostics ${ }^{a}$

\begin{tabular}{|c|c|c|c|c|c|c|}
\hline \multirow[t]{2}{*}{ Model } & \multirow[t]{2}{*}{ Dimension } & \multirow[t]{2}{*}{ Eigenvalue } & \multirow{2}{*}{$\begin{array}{l}\text { Condition } \\
\text { Index }\end{array}$} & \multicolumn{3}{|c|}{ Variance Proportions } \\
\hline & & & & (Constant) & Population & Zone1_Counties \\
\hline \multirow{5}{*}{1} & 1 & 3.834 & 1.000 & .01 & .01 & .01 \\
\hline & 2 & .764 & 2.240 & .00 & .00 & .08 \\
\hline & 3 & 243 & 3.975 & .29 & .07 & .09 \\
\hline & 4 & .119 & 5.686 & .36 & .44 & .07 \\
\hline & 5 & .041 & 9.652 & .33 & .48 & .75 \\
\hline
\end{tabular}




\section{Collinearity Diagnostics $^{\mathrm{a}}$}

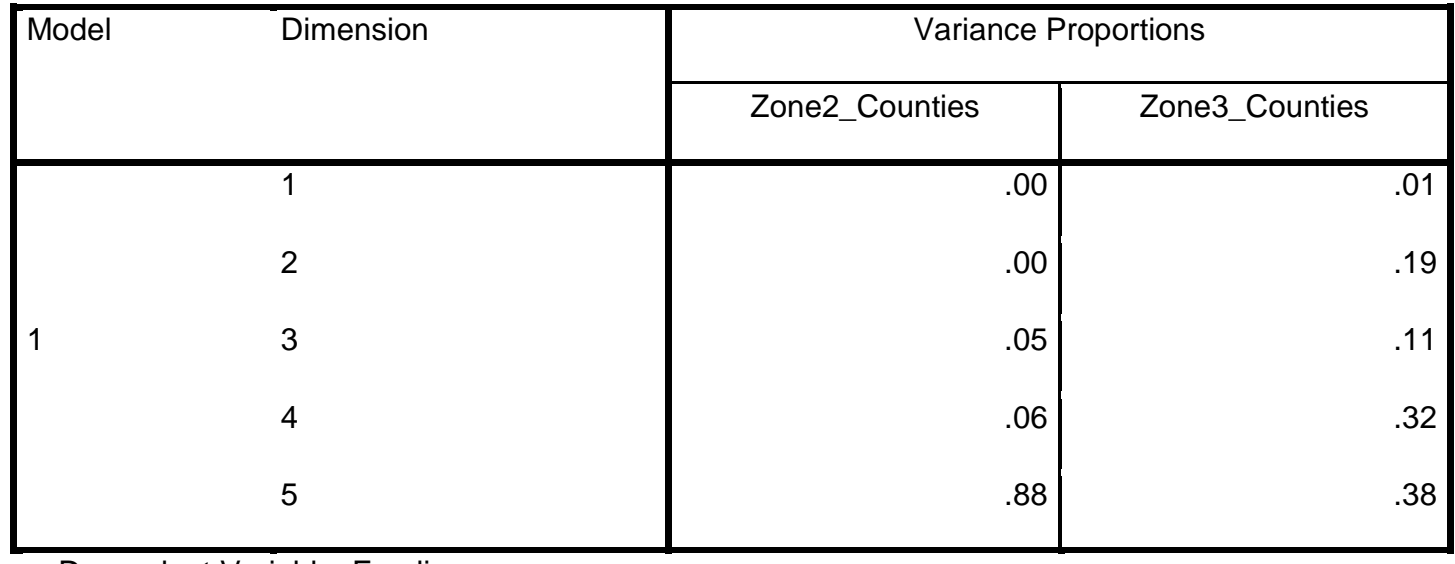

a. Dependent Variable: Funding

Residuals Statistics ${ }^{a}$

\begin{tabular}{|l|r|r|r|r|r|}
\hline & \multicolumn{1}{|c|}{ Minimum } & Maximum & Mean & Std. Deviation & $\mathrm{N}$ \\
\hline Predicted Value & 223602.91 & 1892160.50 & 827634.09 & 509030.138 & 10 \\
Residual & -383755.063 & 378908.188 & .000 & 230552.364 & 10 \\
Std. Predicted Value & -1.187 & 2.091 & .000 & 1.000 & 10 \\
Std. Residual & -1.241 & 1.225 & .000 & .745 & 10 \\
\hline
\end{tabular}

a. Dependent Variable: Funding

Fiscal Year 2003

Descriptive Statistics

\begin{tabular}{|l|r|r|r|}
\hline & \multicolumn{1}{|c|}{ Mean } & Std. Deviation & $\mathrm{N}$ \\
\hline Funding & 892117.35 & 670624.800 & 10 \\
Population & 29032641.80 & 16980276.908 & 10 \\
Zone1_Counties & 107.00 & 103.109 & 10 \\
Zone2_Counties & 103.60 & 78.032 & 10 \\
Zone3_Counties & 103.70 & 155.526 & 10 \\
\hline
\end{tabular}




\section{Correlations}

\begin{tabular}{|c|c|c|c|c|c|}
\hline & & Funding & Population & Zone1_Counties & Zone2_Counties \\
\hline & Funding & 1.000 & .529 & .644 & .719 \\
\hline & Population & .529 & 1.000 & -.019 & .597 \\
\hline $\begin{array}{l}\text { Pearson } \\
\text { Correlation }\end{array}$ & Zone1_Counties & .644 & -.019 & 1.000 & .511 \\
\hline & Zone2_Counties & .719 & .597 & .511 & 1.000 \\
\hline & Zone3_Counties & -.045 & .522 & -.298 & .470 \\
\hline & Funding & & .058 & .022 & .010 \\
\hline & Population & .058 & . & 479 & .034 \\
\hline Sig. (1-tailed) & Zone1_Counties & .022 & .479 & & .066 \\
\hline & Zone2_Counties & .010 & .034 & .066 & \\
\hline & Zone3_Counties & 451 & .061 & 201 & .085 \\
\hline & Funding & 10 & 10 & 10 & 10 \\
\hline & Population & 10 & 10 & 10 & 10 \\
\hline $\mathrm{N}$ & Zone1_Counties & 10 & 10 & 10 & 10 \\
\hline & Zone2_Counties & 10 & 10 & 10 & 10 \\
\hline & Zone3_Counties & 10 & 10 & 10 & 10 \\
\hline
\end{tabular}




\section{Correlations}

\begin{tabular}{|c|c|c|}
\hline & & Zone3_Counties \\
\hline & Funding & -.045 \\
\hline & Population & .522 \\
\hline Pearson Correlation & Zone1_Counties & -.298 \\
\hline & Zone2_Counties & 470 \\
\hline & Zone3_Counties & 1.000 \\
\hline & Funding & .451 \\
\hline & Population & .061 \\
\hline Sig. (1-tailed) & Zone1_Counties & 201 \\
\hline & Zone2_Counties & .085 \\
\hline & Zone3_Counties & \\
\hline & Funding & 10 \\
\hline & Population & 10 \\
\hline $\mathrm{N}$ & Zone1_Counties & 10 \\
\hline & Zone2_Counties & 10 \\
\hline & Zone3_Counties & 10 \\
\hline
\end{tabular}

Variables Entered/Removed ${ }^{\mathrm{a}}$

\begin{tabular}{|l|l|l|l|}
\hline Model & $\begin{array}{c}\text { Variables } \\
\text { Entered }\end{array}$ & $\begin{array}{l}\text { Variables } \\
\text { Removed }\end{array}$ & Method \\
\hline 1 & $\begin{array}{l}\text { Zone3_Counties } \\
\text { Zone1_Counties } \\
\text { Zon_lation, } \\
\text { Zone2_Counties } \\
\text { bones }\end{array}$ & & Enter \\
\hline
\end{tabular}

a. Dependent Variable: Funding

b. All requested variables entered. 
Model Summary

\begin{tabular}{|l|r|r|r|r|r|r|r|}
\hline Model & $\mathrm{R}$ & $\mathrm{R}$ Square & \multicolumn{1}{|c|}{$\begin{array}{c}\text { Adjusted R } \\
\text { Square }\end{array}$} & & & $\begin{array}{c}\text { Std. Error of } \\
\text { the Estimate }\end{array}$ & \multicolumn{3}{|c|}{ Change Statistics } \\
\cline { 5 - 8 } & & & & & $\begin{array}{c}\text { R Square } \\
\text { Change }\end{array}$ & F Change & df1 \\
\hline 1 & $.897^{\mathrm{a}}$ & .805 & .650 & 397010.041 & .805 & 5.170 & 4 \\
\hline
\end{tabular}

Model Summary ${ }^{\mathrm{b}}$

\begin{tabular}{|l|r|rr|}
\hline \multirow{2}{*}{ Model } & \multicolumn{3}{|c|}{ Change Statistics } \\
\cline { 2 - 4 } & \multicolumn{2}{|c|}{ Sig. F Change } \\
\hline 1 & & $5^{\mathrm{a}}$ & \\
\hline
\end{tabular}

a. Predictors: (Constant), Zone3_Counties, Zone1_Counties, Population, Zone2_Counties

b. Dependent Variable: Funding

ANOVA $^{\mathrm{a}}$

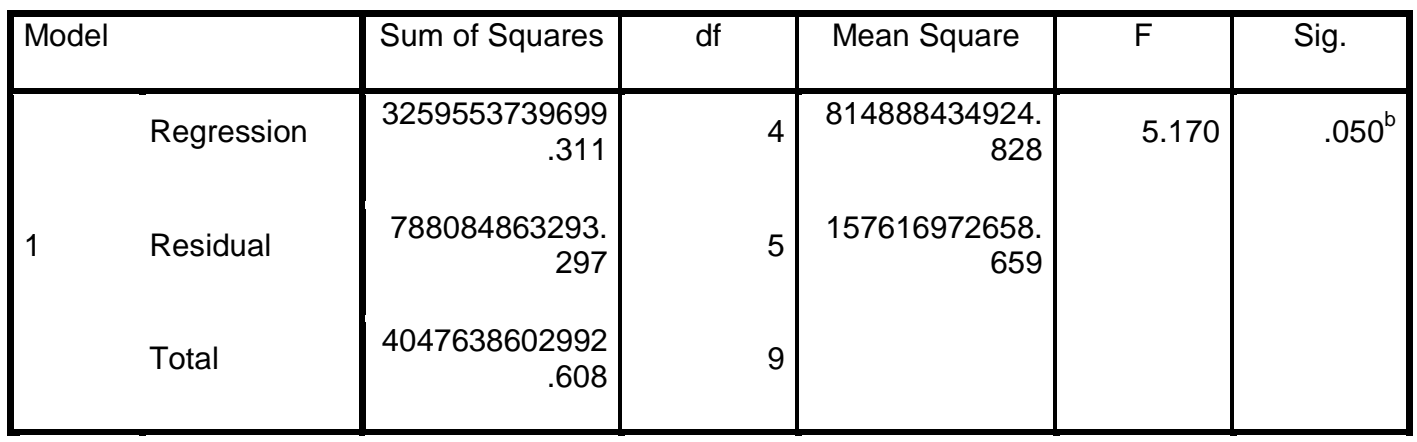

a. Dependent Variable: Funding

b. Predictors: (Constant), Zone3_Counties, Zone1_Counties, Population, Zone2_Counties 
Coefficients $^{\mathrm{a}}$

\begin{tabular}{|c|c|c|c|c|c|c|}
\hline \multirow{2}{*}{\multicolumn{2}{|c|}{ Model }} & \multicolumn{2}{|c|}{ Unstandardized Coefficients } & \multirow{2}{*}{$\begin{array}{c}\text { Standardized } \\
\text { Coefficients }\end{array}$} & \multirow[t]{2}{*}{$\mathrm{t}$} & \multirow[t]{2}{*}{ Sig. } \\
\hline & & $B$ & Std. Error & & & \\
\hline \multirow{5}{*}{1} & (Constant) & -63867.126 & 306602.272 & & -.208 & .843 \\
\hline & Population & .018 & .011 & .447 & 1.604 & 170 \\
\hline & Zone1_Counties & 1470.104 & 2260.416 & 226 & .650 & .544 \\
\hline & Zone2_Counties & 4805.276 & 3601.468 & .559 & 1.334 & 240 \\
\hline & Zone3_Counties & -2042.677 & 1369.936 & -.474 & -1.491 & .196 \\
\hline
\end{tabular}

\begin{tabular}{|c|c|c|c|c|c|c|}
\hline \multirow{2}{*}{\multicolumn{2}{|c|}{ Model }} & \multicolumn{3}{|c|}{ Correlations } & \multicolumn{2}{|c|}{ Collinearity Statistics } \\
\hline & & Zero-order & Partial & Part & Tolerance & VIF \\
\hline \multirow{5}{*}{1} & (Constant) & & & & & \\
\hline & Population & .529 & .583 & .316 & .501 & 1.997 \\
\hline & Zone1_Counties & .644 & .279 & .128 & .322 & 3.102 \\
\hline & Zone2_Counties & .719 & .512 & .263 & .222 & 4.510 \\
\hline & Zone3_Counties & -.045 & -.555 & -.294 & .386 & 2.592 \\
\hline
\end{tabular}

a. Dependent Variable: Funding

\section{Collinearity Diagnostics $^{a}$}

\begin{tabular}{|c|c|c|c|c|c|c|}
\hline \multirow[t]{2}{*}{ Model } & \multirow[t]{2}{*}{ Dimension } & \multirow[t]{2}{*}{ Eigenvalue } & \multirow{2}{*}{$\begin{array}{l}\text { Condition } \\
\text { Index }\end{array}$} & \multicolumn{3}{|c|}{ Variance Proportions } \\
\hline & & & & (Constant) & Population & Zone1_Counties \\
\hline \multirow{5}{*}{1} & 1 & 3.833 & 1.000 & .01 & .01 & .01 \\
\hline & 2 & .765 & 2.239 & .00 & .00 & .08 \\
\hline & 3 & .243 & 3.974 & .29 & .07 & .09 \\
\hline & 4 & .118 & 5.688 & .36 & .44 & .07 \\
\hline & 5 & .041 & 9.660 & .33 & .48 & .75 \\
\hline
\end{tabular}


Collinearity Diagnostics ${ }^{a}$

\begin{tabular}{|c|c|c|c|}
\hline \multirow[t]{2}{*}{ Model } & \multirow[t]{2}{*}{ Dimension } & \multicolumn{2}{|c|}{ Variance Proportions } \\
\hline & & Zone2_Counties & Zone3_Counties \\
\hline \multirow{5}{*}{1} & 1 & .00 & .01 \\
\hline & 2 & .00 & .19 \\
\hline & 3 & .05 & .11 \\
\hline & 4 & .06 & .32 \\
\hline & 5 & .88 & .37 \\
\hline
\end{tabular}

a. Dependent Variable: Funding

Residuals Statistics ${ }^{a}$

\begin{tabular}{|l|r|r|r|r|r|}
\hline & \multicolumn{1}{|c|}{ Minimum } & Maximum & \multicolumn{1}{|c|}{ Mean } & Std. Deviation & N \\
\hline Predicted Value & 147280.41 & 2136123.00 & 892117.35 & 601807.808 & 10 \\
Residual & -441524.563 & 517012.000 & .000 & 295913.813 & 10 \\
Std. Predicted Value & -1.238 & 2.067 & .000 & 1.000 & 10 \\
Std. Residual & -1.112 & 1.302 & .000 & .745 & 10 \\
\hline
\end{tabular}

a. Dependent Variable: Funding

Fiscal Year 2004

Descriptive Statistics

\begin{tabular}{|l|r|r|r|}
\hline & \multicolumn{1}{|c|}{ Mean } & Std. Deviation & $\mathrm{N}$ \\
\hline Funding & 824806.50 & 608969.637 & 10 \\
Population & 29305892.40 & 17193002.829 & 10 \\
Zone1_Counties & 107.00 & 103.109 & 10 \\
Zone2_Counties & 103.60 & 78.032 & 10 \\
Zone3_Counties & 103.70 & 155.526 & 10 \\
\hline
\end{tabular}

Correlations 


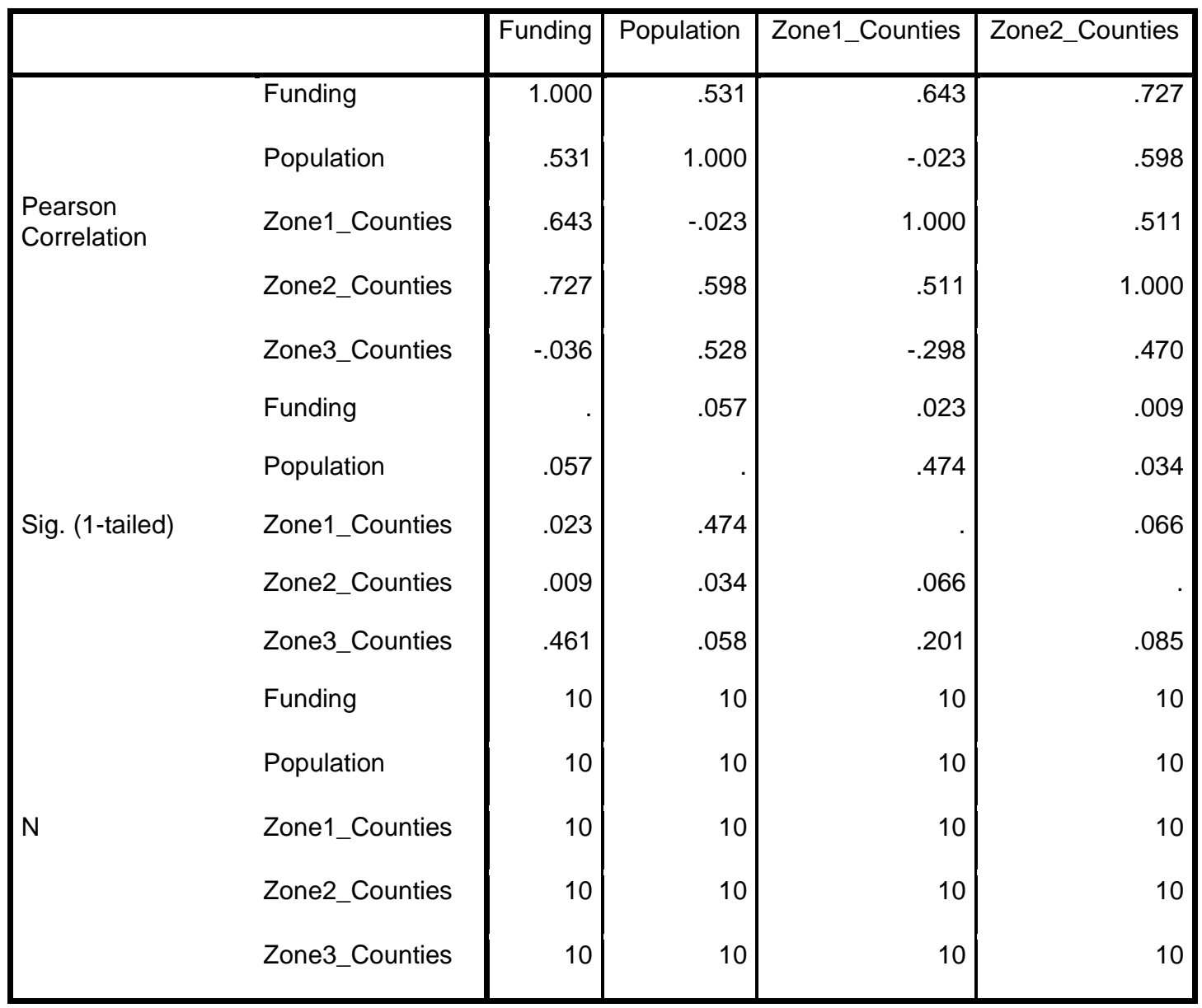




\section{Correlations}

\begin{tabular}{|c|c|c|}
\hline & & Zone3_Counties \\
\hline \multirow{6}{*}{ Pearson Correlation } & $\begin{array}{l}\text { Funding } \\
\text { Population }\end{array}$ & $\begin{array}{r}-.036 \\
.528\end{array}$ \\
\hline & Zone1_Counties & -.298 \\
\hline & Zone2_Counties & 470 \\
\hline & Zone3_Counties & 1.000 \\
\hline & Funding & .461 \\
\hline & Population & .058 \\
\hline \multirow[t]{5}{*}{ Sig. (1-tailed) } & Zone1_Counties & 201 \\
\hline & Zone2_Counties & .085 \\
\hline & Zone3_Counties & \\
\hline & Funding & 10 \\
\hline & Population & 10 \\
\hline \multirow[t]{3}{*}{$\mathrm{N}$} & Zone1_Counties & 10 \\
\hline & Zone2_Counties & 10 \\
\hline & Zone3_Counties & 10 \\
\hline
\end{tabular}

Variables Entered/Removed $^{\mathrm{a}}$

\begin{tabular}{|c|c|c|c|}
\hline Model & $\begin{array}{c}\text { Variables } \\
\text { Entered }\end{array}$ & $\begin{array}{c}\text { Variables } \\
\text { Removed }\end{array}$ & Method \\
\hline 1 & $\begin{array}{l}\text { Zone3_Counties } \\
\text { Zone1_Counties } \\
\text { Population, } \\
\text { Zone2_Counties } \\
\text { bones }\end{array}$ & & \\
& & & \\
\hline
\end{tabular}

a. Dependent Variable: Funding

b. All requested variables entered. 
Model Summary

\begin{tabular}{|c|c|c|c|c|c|c|c|}
\hline \multirow[t]{2}{*}{ Model } & \multirow[t]{2}{*}{$\mathrm{R}$} & \multirow[t]{2}{*}{ R Square } & \multirow{2}{*}{$\begin{array}{l}\text { Adjusted R } \\
\text { Square }\end{array}$} & \multirow{2}{*}{$\begin{array}{l}\text { Std. Error of the } \\
\text { Estimate }\end{array}$} & \multicolumn{3}{|c|}{ Change Statistics } \\
\hline & & & & & $\begin{array}{c}\text { R Square } \\
\text { Change }\end{array}$ & $\begin{array}{c}\mathrm{F} \\
\text { Change }\end{array}$ & df1 \\
\hline 1 & $.900^{\mathrm{a}}$ & .809 & .657 & 356729.645 & .809 & 5.307 & 4 \\
\hline
\end{tabular}

Model Summary ${ }^{\mathrm{b}}$

\begin{tabular}{|l|r|rr|}
\hline \multirow{2}{*}{ Model } & \multicolumn{3}{|c|}{ Change Statistics } \\
\cline { 2 - 4 } & \multicolumn{2}{|c|}{ Sig. F Change } \\
\hline 1 & & $5^{\mathrm{a}}$ & \\
\hline
\end{tabular}

a. Predictors: (Constant), Zone3_Counties, Zone1_Counties, Population, Zone2_Counties

b. Dependent Variable: Funding

ANOVA $^{\mathrm{a}}$

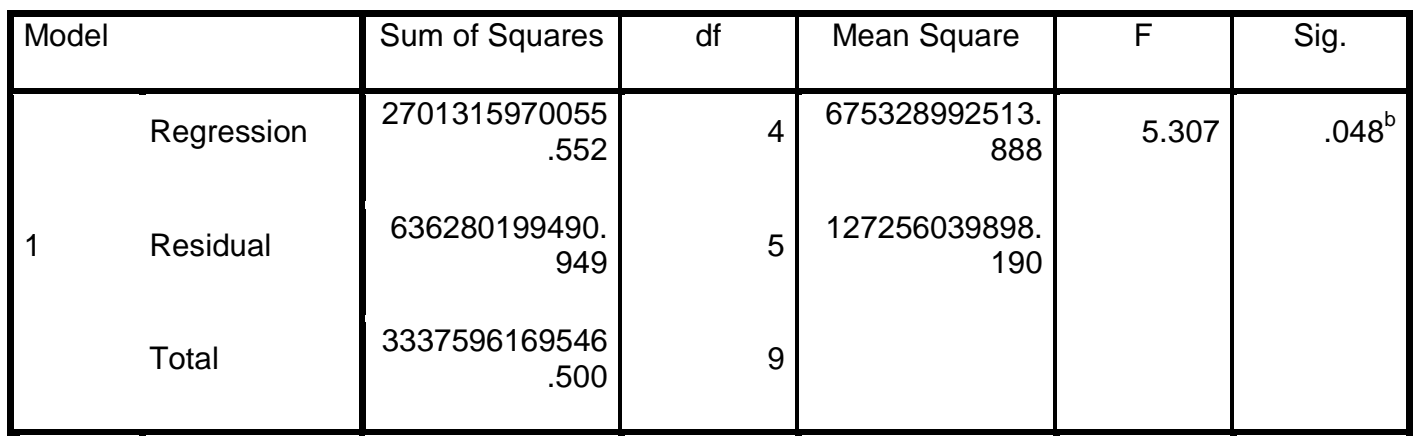

a. Dependent Variable: Funding

b. Predictors: (Constant), Zone3_Counties, Zone1_Counties, Population, Zone2_Counties 
Coefficients $^{\mathrm{a}}$

\begin{tabular}{|c|c|c|c|c|c|c|}
\hline \multirow{2}{*}{\multicolumn{2}{|c|}{ Model }} & \multicolumn{2}{|c|}{ Unstandardized Coefficients } & \multirow{2}{*}{$\begin{array}{c}\text { Standardized } \\
\text { Coefficients }\end{array}$} & \multirow[t]{2}{*}{$\mathrm{t}$} & \multirow[t]{2}{*}{ Sig. } \\
\hline & & $B$ & Std. Error & & & \\
\hline \multirow{5}{*}{1} & (Constant) & -44295.288 & 275444.423 & & -.161 & .879 \\
\hline & Population & .016 & .010 & .443 & 1.598 & .171 \\
\hline & Zone1_Counties & 1289.651 & 2033.599 & 218 & .634 & .554 \\
\hline & Zone2_Counties & 4476.054 & 3240.242 & .574 & 1.381 & 226 \\
\hline & Zone3_Counties & -1856.733 & 1231.012 & -.474 & -1.508 & .192 \\
\hline
\end{tabular}

\begin{tabular}{|l|r|r|r|r|r|}
\hline \multirow{2}{*}{ Model Correlations } & \multicolumn{3}{|c|}{ Collinearity Statistics } \\
\cline { 2 - 6 } & Zero-order & \multicolumn{1}{|c|}{ Partial } & \multicolumn{1}{c|}{ Part } & Tolerance & \multicolumn{1}{c|}{ VIF } \\
\hline \multirow{2}{*}{ (Constant) } & .531 & .581 & .312 & .496 & 2.016 \\
Population & .643 & .273 & .124 & .322 & 3.110 \\
Zone1_Counties & .727 & .526 & .270 & .221 & 4.521 \\
Zone2_Counties & -.036 & -.559 & -.295 & .386 & 2.592 \\
Zone3_Counties & & & & & \\
\hline
\end{tabular}

a. Dependent Variable: Funding

\section{Collinearity Diagnostics ${ }^{a}$}

\begin{tabular}{|c|c|c|c|c|c|c|}
\hline \multirow[t]{2}{*}{ Model } & \multirow[t]{2}{*}{ Dimension } & \multirow[t]{2}{*}{ Eigenvalue } & \multirow{2}{*}{$\begin{array}{l}\text { Condition } \\
\text { Index }\end{array}$} & \multicolumn{3}{|c|}{ Variance Proportions } \\
\hline & & & & (Constant) & Population & Zone1_Counties \\
\hline \multirow{5}{*}{1} & 1 & 3.833 & 1.000 & .01 & .01 & .01 \\
\hline & 2 & .765 & 2.238 & .00 & .00 & .08 \\
\hline & 3 & .242 & 3.977 & .30 & .07 & .09 \\
\hline & 4 & .118 & 5.692 & .36 & .44 & .07 \\
\hline & 5 & .041 & 9.675 & .33 & .48 & .76 \\
\hline
\end{tabular}


Collinearity Diagnostics ${ }^{a}$

\begin{tabular}{|c|c|c|c|}
\hline \multirow[t]{2}{*}{ Model } & \multirow[t]{2}{*}{ Dimension } & \multicolumn{2}{|c|}{ Variance Proportions } \\
\hline & & Zone2_Counties & Zone3_Counties \\
\hline \multirow{5}{*}{1} & 1 & .00 & .01 \\
\hline & 2 & .00 & .18 \\
\hline & 3 & .05 & .11 \\
\hline & 4 & .06 & .33 \\
\hline & 5 & .88 & .37 \\
\hline
\end{tabular}

a. Dependent Variable: Funding

Residuals Statistics ${ }^{a}$

\begin{tabular}{|l|r|r|r|r|r|}
\hline & \multicolumn{1}{|c|}{ Minimum } & Maximum & \multicolumn{1}{|c|}{ Mean } & Std. Deviation & \multicolumn{1}{|c|}{ N } \\
\hline Predicted Value & 151318.77 & 1949953.88 & 824806.50 & 547856.020 & 10 \\
Residual & -447420.313 & 444609.125 & .000 & 265890.579 & 10 \\
Std. Predicted Value & -1.229 & 2.054 & .000 & 1.000 & 10 \\
Std. Residual & -1.254 & 1.246 & .000 & .745 & 10 \\
\hline
\end{tabular}

a. Dependent Variable: Funding

Fiscal Year 2005

Descriptive Statistics

\begin{tabular}{|l|r|r|r|}
\hline & \multicolumn{1}{|c|}{ Mean } & Std. Deviation & N \\
\hline Funding & 868134.00 & 546158.762 & 10 \\
Population & 29576591.00 & 17405638.277 & 10 \\
Zone1_Counties & 107.00 & 103.109 & 10 \\
Zone2_Counties & 103.60 & 78.032 & 10 \\
Zone3_Counties & 103.70 & 155.526 & 10 \\
\hline
\end{tabular}




\section{Correlations}

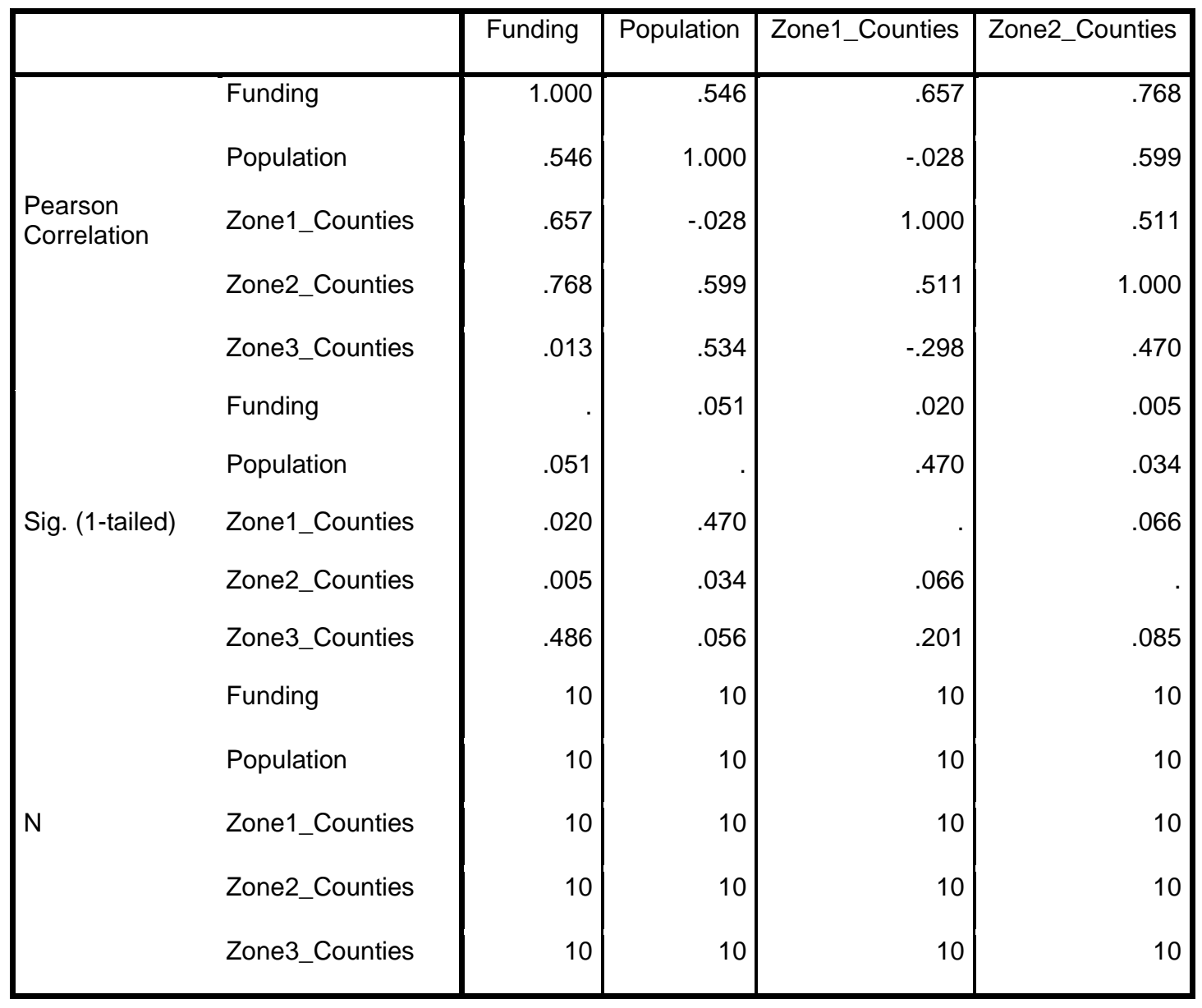




\section{Correlations}

\begin{tabular}{|c|c|c|}
\hline & & Zone3_Counties \\
\hline \multirow{6}{*}{ Pearson Correlation } & $\begin{array}{l}\text { Funding } \\
\text { Population }\end{array}$ & $\begin{array}{l}.013 \\
.534\end{array}$ \\
\hline & Zone1_Counties & -.298 \\
\hline & Zone2_Counties & .470 \\
\hline & Zone3_Counties & 1.000 \\
\hline & Funding & .486 \\
\hline & Population & .056 \\
\hline \multirow[t]{5}{*}{ Sig. (1-tailed) } & Zone1_Counties & .201 \\
\hline & Zone2_Counties & .085 \\
\hline & Zone3_Counties & \\
\hline & Funding & 10 \\
\hline & Population & 10 \\
\hline \multirow[t]{3}{*}{$\mathrm{N}$} & Zone1_Counties & 10 \\
\hline & Zone2_Counties & 10 \\
\hline & Zone3_Counties & 10 \\
\hline
\end{tabular}

\section{Variables Entered/Removed $^{\mathrm{a}}$}

\begin{tabular}{|l|l|l|l|}
\hline Model & \multicolumn{1}{|c|}{$\begin{array}{c}\text { Variables } \\
\text { Entered }\end{array}$} & $\begin{array}{c}\text { Variables } \\
\text { Removed }\end{array}$ & Method \\
\hline 1 & $\begin{array}{l}\text { Zone3_Counties } \\
\text { Zone1_Counties } \\
\text { Population, } \\
\text { Zone2_Counties } \\
\mathrm{b}\end{array}$ & & \\
& & Enter \\
\hline
\end{tabular}

a. Dependent Variable: Funding

b. All requested variables entered. 
Model Summary

\begin{tabular}{|c|c|c|c|c|c|c|c|}
\hline \multirow[t]{2}{*}{ Model } & \multirow[t]{2}{*}{$\mathrm{R}$} & \multirow[t]{2}{*}{ R Square } & \multirow{2}{*}{$\begin{array}{l}\text { Adjusted R } \\
\text { Square }\end{array}$} & \multirow{2}{*}{$\begin{array}{l}\text { Std. Error of the } \\
\text { Estimate }\end{array}$} & \multicolumn{3}{|c|}{ Change Statistics } \\
\hline & & & & & $\begin{array}{c}\text { R Square } \\
\text { Change }\end{array}$ & $\begin{array}{c}\mathrm{F} \\
\text { Change }\end{array}$ & df1 \\
\hline 1 & $.914^{\mathrm{a}}$ & .836 & .704 & 297084.021 & .836 & 6.354 & 4 \\
\hline
\end{tabular}

Model Summary ${ }^{\mathrm{b}}$

\begin{tabular}{|l|r|rr|}
\hline \multirow{2}{*}{ Model } & \multicolumn{3}{|c|}{ Change Statistics } \\
\cline { 2 - 4 } & \multicolumn{2}{|c|}{ Sig. F Change } \\
\hline 1 & & $5^{\mathrm{a}}$ & \\
\hline
\end{tabular}

a. Predictors: (Constant), Zone3_Counties, Zone1_Counties, Population, Zone2_Counties

b. Dependent Variable: Funding

ANOVA $^{\mathrm{a}}$

\begin{tabular}{|c|c|c|c|c|c|}
\hline Model & Sum of Squares & df & Mean Square & $\mathrm{F}$ & Sig. \\
\hline $\begin{array}{l}\text { Regression } \\
\text { Residual } \\
\text { Total }\end{array}$ & $\begin{array}{r}2243309966425 \\
.851 \\
\\
441294576652 . \\
150 \\
\\
2684604543078 \\
.000\end{array}$ & $\begin{array}{l}5 \\
9\end{array}$ & $\begin{array}{r}560827491606 . \\
463 \\
88258915330.4 \\
30\end{array}$ & 6.354 & $.034^{b}$ \\
\hline
\end{tabular}

a. Dependent Variable: Funding

b. Predictors: (Constant), Zone3_Counties, Zone1_Counties, Population, Zone2_Counties 
Coefficients $^{\mathrm{a}}$

\begin{tabular}{|c|c|c|c|c|c|c|}
\hline \multirow{2}{*}{\multicolumn{2}{|c|}{ Model }} & \multicolumn{2}{|c|}{ Unstandardized Coefficients } & \multirow{2}{*}{$\begin{array}{c}\text { Standardized } \\
\text { Coefficients }\end{array}$} & \multirow[t]{2}{*}{$\mathrm{t}$} & \multirow[t]{2}{*}{ Sig. } \\
\hline & & B & Std. Error & & & \\
\hline \multirow{5}{*}{1} & (Constant) & 61107.575 & 229403.208 & & 266 & .801 \\
\hline & Population & .013 & .008 & 427 & 1.649 & 160 \\
\hline & Zone1_Counties & 1327.412 & 1696.010 & 251 & .783 & .469 \\
\hline & Zone2_Counties & 4040.843 & 2703.374 & .577 & 1.495 & 195 \\
\hline & Zone3_Counties & -1446.885 & 1025.286 & -.412 & -1.411 & .217 \\
\hline
\end{tabular}

\begin{tabular}{|c|c|c|c|c|c|c|}
\hline \multirow{2}{*}{\multicolumn{2}{|c|}{ Model }} & \multicolumn{3}{|c|}{ Correlations } & \multicolumn{2}{|c|}{ Collinearity Statistics } \\
\hline & & Zero-order & Partial & Part & Tolerance & VIF \\
\hline \multirow{5}{*}{1} & (Constant) & & & & & \\
\hline & Population & .546 & .593 & .299 & .490 & 2.042 \\
\hline & Zone1_Counties & .657 & .330 & .142 & .321 & 3.118 \\
\hline & Zone2_Counties & .768 & .556 & .271 & .220 & 4.538 \\
\hline & Zone3_Counties & .013 & -.534 & -.256 & .386 & 2.593 \\
\hline
\end{tabular}

a. Dependent Variable: Funding

\section{Collinearity Diagnostics $^{a}$}

\begin{tabular}{|c|c|c|c|c|c|c|}
\hline \multirow[t]{2}{*}{ Model } & \multirow[t]{2}{*}{ Dimension } & \multirow[t]{2}{*}{ Eigenvalue } & \multirow{2}{*}{$\begin{array}{l}\text { Condition } \\
\text { Index }\end{array}$} & \multicolumn{3}{|c|}{ Variance Proportions } \\
\hline & & & & (Constant) & Population & Zone1_Counties \\
\hline \multirow{5}{*}{1} & 1 & 3.833 & 1.000 & .01 & .01 & .01 \\
\hline & 2 & .766 & 2.237 & .00 & .00 & .08 \\
\hline & 3 & 242 & 3.982 & .30 & .06 & .09 \\
\hline & 4 & .118 & 5.700 & .35 & .44 & .07 \\
\hline & 5 & .041 & 9.696 & .33 & .49 & .76 \\
\hline
\end{tabular}


Collinearity Diagnostics ${ }^{a}$

\begin{tabular}{|c|c|c|c|}
\hline \multirow[t]{2}{*}{ Model } & \multirow[t]{2}{*}{ Dimension } & \multicolumn{2}{|c|}{ Variance Proportions } \\
\hline & & Zone2_Counties & Zone3_Counties \\
\hline \multirow{5}{*}{1} & 1 & .00 & .01 \\
\hline & 2 & .00 & .18 \\
\hline & 3 & .05 & .11 \\
\hline & 4 & .06 & .34 \\
\hline & 5 & .88 & .36 \\
\hline
\end{tabular}

a. Dependent Variable: Funding

Residuals Statistics ${ }^{a}$

\begin{tabular}{|l|r|r|r|r|r|}
\hline & \multicolumn{1}{|c|}{ Minimum } & Maximum & \multicolumn{1}{|c|}{ Mean } & Std. Deviation & N \\
\hline Predicted Value & 311794.72 & 1878937.25 & 868134.00 & 499256.110 & 10 \\
Residual & -392617.375 & 354264.938 & .000 & 221433.355 & 10 \\
Std. Predicted Value & -1.114 & 2.025 & .000 & 1.000 & 10 \\
Std. Residual & -1.322 & 1.192 & .000 & .745 & 10 \\
\hline
\end{tabular}

a. Dependent Variable: Funding

Fiscal Year 2006

Descriptive Statistics

\begin{tabular}{|l|r|r|r|}
\hline & \multicolumn{1}{|c|}{ Mean } & Std. Deviation & $\mathrm{N}$ \\
\hline Funding & 842163.20 & 516171.750 & 10 \\
Population & 29859321.20 & 17608241.988 & 10 \\
Zone1_Counties & 107.00 & 103.109 & 10 \\
Zone2_Counties & 103.60 & 78.032 & 10 \\
Zone3_Counties & 103.70 & 155.526 & 10 \\
\hline
\end{tabular}


Correlations

\begin{tabular}{|c|c|c|c|c|c|}
\hline & & Funding & Population & Zone1_Counties & Zone2_Counties \\
\hline \multirow{7}{*}{$\begin{array}{l}\text { Pearson } \\
\text { Correlation }\end{array}$} & Funding & 1.000 & .625 & .549 & .810 \\
\hline & Population & .625 & 1.000 & -.030 & .602 \\
\hline & Zone1_Counties & .549 & -.030 & 1.000 & .511 \\
\hline & Zone2_Counties & .810 & .602 & .511 & 1.000 \\
\hline & Zone3_Counties & .148 & .541 & -.298 & .470 \\
\hline & Funding & & .027 & .050 & .002 \\
\hline & Population & .027 & & .467 & .033 \\
\hline \multirow[t]{5}{*}{ Sig. (1-tailed) } & Zone1_Counties & .050 & .467 & & .066 \\
\hline & Zone2_Counties & .002 & .033 & .066 & \\
\hline & Zone3_Counties & .342 & .053 & .201 & .085 \\
\hline & Funding & 10 & 10 & 10 & 10 \\
\hline & Population & 10 & 10 & 10 & 10 \\
\hline \multirow[t]{3}{*}{$N$} & Zone1_Counties & 10 & 10 & 10 & 10 \\
\hline & Zone2_Counties & 10 & 10 & 10 & 10 \\
\hline & Zone3_Counties & 10 & 10 & 10 & 10 \\
\hline
\end{tabular}




\section{Correlations}

\begin{tabular}{|c|c|c|}
\hline & & Zone3_Counties \\
\hline \multirow{6}{*}{ Pearson Correlation } & $\begin{array}{l}\text { Funding } \\
\text { Population }\end{array}$ & $\begin{array}{l}.148 \\
.541\end{array}$ \\
\hline & Zone1_Counties & -.298 \\
\hline & Zone2_Counties & .470 \\
\hline & Zone3_Counties & 1.000 \\
\hline & Funding & .342 \\
\hline & Population & .053 \\
\hline \multirow[t]{5}{*}{ Sig. (1-tailed) } & Zone1_Counties & 201 \\
\hline & Zone2_Counties & .085 \\
\hline & Zone3_Counties & \\
\hline & Funding & 10 \\
\hline & Population & 10 \\
\hline \multirow[t]{3}{*}{$\mathrm{N}$} & Zone1_Counties & 10 \\
\hline & Zone2_Counties & 10 \\
\hline & Zone3_Counties & 10 \\
\hline
\end{tabular}

\section{Variables Entered/Removed $^{\mathrm{a}}$}

\begin{tabular}{|l|l|l|l|}
\hline Model & \multicolumn{1}{|c|}{$\begin{array}{c}\text { Variables } \\
\text { Entered }\end{array}$} & $\begin{array}{c}\text { Variables } \\
\text { Removed }\end{array}$ & Method \\
\hline 1 & $\begin{array}{l}\text { Zone3_Counties } \\
\text { Zone1_Counties } \\
\text { Zon_lation, } \\
\text { Zone2_Counties } \\
\text { bones }\end{array}$ & & \\
\hline
\end{tabular}

a. Dependent Variable: Funding

b. All requested variables entered. 
Model Summary

\begin{tabular}{|c|c|c|c|c|c|c|c|}
\hline \multirow[t]{2}{*}{ Model } & \multirow[t]{2}{*}{$\mathrm{R}$} & \multirow[t]{2}{*}{ R Square } & \multirow{2}{*}{$\begin{array}{l}\text { Adjusted R } \\
\text { Square }\end{array}$} & \multirow{2}{*}{$\begin{array}{l}\text { Std. Error of the } \\
\text { Estimate }\end{array}$} & \multicolumn{3}{|c|}{ Change Statistics } \\
\hline & & & & & $\begin{array}{c}\text { R Square } \\
\text { Change }\end{array}$ & $\begin{array}{c}\mathrm{F} \\
\text { Change }\end{array}$ & df1 \\
\hline 1 & $.902^{\mathrm{a}}$ & .813 & .664 & 299076.535 & .813 & 5.452 & 4 \\
\hline
\end{tabular}

Model Summary ${ }^{\mathrm{b}}$

\begin{tabular}{|l|r|rr|}
\hline \multirow{2}{*}{ Model } & \multicolumn{3}{|c|}{ Change Statistics } \\
\cline { 2 - 4 } & \multicolumn{2}{|c|}{ Sig. F Change } \\
\hline 1 & $5^{\mathrm{a}}$ & & .046 \\
\hline
\end{tabular}

a. Predictors: (Constant), Zone3_Counties, Zone1_Counties, Population, Zone2_Counties

b. Dependent Variable: Funding

ANOVA $^{\mathrm{a}}$

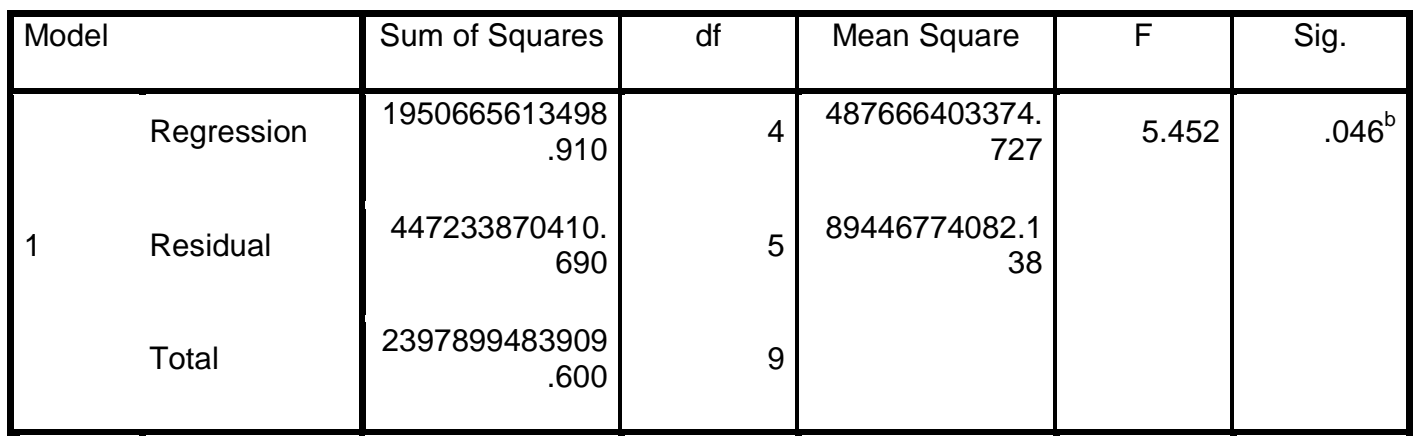

a. Dependent Variable: Funding

b. Predictors: (Constant), Zone3_Counties, Zone1_Counties, Population, Zone2_Counties 
Coefficients $^{\mathrm{a}}$

\begin{tabular}{|c|c|c|c|c|c|c|}
\hline \multirow{2}{*}{\multicolumn{2}{|c|}{ Model }} & \multicolumn{2}{|c|}{ Unstandardized Coefficients } & \multirow{2}{*}{$\begin{array}{c}\begin{array}{c}\text { Standardized } \\
\text { Coefficients }\end{array} \\
\text { Beta }\end{array}$} & \multirow[t]{2}{*}{$\mathrm{t}$} & \multirow[t]{2}{*}{ Sig. } \\
\hline & & B & Std. Error & & & \\
\hline \multirow{5}{*}{1} & (Constant) & 79247.844 & 231046.632 & & .343 & .746 \\
\hline & Population & .012 & .008 & .421 & 1.514 & .190 \\
\hline & Zone1_Counties & 561.533 & 1709.805 & .112 & .328 & .756 \\
\hline & Zone2_Counties & 4427.539 & 2728.274 & 669 & 1.623 & .166 \\
\hline & Zone3_Counties & -1197.459 & 1032.279 & -.361 & -1.160 & .298 \\
\hline
\end{tabular}

Coefficients $^{\mathrm{a}}$

\begin{tabular}{|c|c|c|c|c|c|c|}
\hline \multirow[t]{2}{*}{ Mod } & & \multicolumn{3}{|c|}{ Correlations } & \multicolumn{2}{|c|}{$\begin{array}{l}\text { Collinearity } \\
\text { Statistics }\end{array}$} \\
\hline & & Zero-order & Partial & Part & Tolerance & VIF \\
\hline \multirow{5}{*}{1} & (Constant) & & & & & \\
\hline & Population & .625 & .561 & 292 & .483 & 2.071 \\
\hline & Zone1_Counties & .549 & .145 & .063 & .320 & 3.127 \\
\hline & Zone2_Counties & .810 & .587 & .313 & .219 & 4.560 \\
\hline & Zone3_Counties & .148 & -.460 & -.224 & .386 & 2.593 \\
\hline
\end{tabular}

a. Dependent Variable: Funding

Collinearity Diagnostics ${ }^{a}$

\begin{tabular}{|c|c|c|c|c|c|c|}
\hline \multirow[t]{2}{*}{ Model } & \multirow[t]{2}{*}{ Dimension } & \multirow[t]{2}{*}{ Eigenvalue } & \multirow{2}{*}{$\begin{array}{l}\text { Condition } \\
\text { Index }\end{array}$} & \multicolumn{3}{|c|}{ Variance Proportions } \\
\hline & & & & (Constant) & Population & Zone1_Counties \\
\hline \multirow{5}{*}{1} & 1 & 3.834 & 1.000 & .01 & .01 & .01 \\
\hline & 2 & .767 & 2.236 & .00 & .00 & .08 \\
\hline & 3 & .241 & 3.987 & .30 & .06 & .09 \\
\hline & 4 & .118 & 5.710 & .35 & .43 & .07 \\
\hline & 5 & .041 & 9.726 & .34 & .49 & .76 \\
\hline
\end{tabular}


Collinearity Diagnostics ${ }^{a}$

\begin{tabular}{|c|c|c|c|}
\hline \multirow[t]{2}{*}{ Model } & \multirow[t]{2}{*}{ Dimension } & \multicolumn{2}{|c|}{ Variance Proportions } \\
\hline & & Zone2_Counties & Zone3_Counties \\
\hline \multirow{5}{*}{1} & 1 & .00 & .01 \\
\hline & 2 & .00 & .18 \\
\hline & 3 & .05 & .11 \\
\hline & 4 & .06 & .35 \\
\hline & 5 & .88 & .35 \\
\hline
\end{tabular}

a. Dependent Variable: Funding

Residuals Statistics ${ }^{a}$

\begin{tabular}{|l|r|r|r|r|r|}
\hline & \multicolumn{1}{|c|}{ Minimum } & Maximum & \multicolumn{1}{|c|}{ Mean } & Std. Deviation & N \\
\hline Predicted Value & 427575.94 & 1727566.25 & 842163.20 & 465554.104 & 10 \\
Residual & -368517.781 & 401515.344 & .000 & 222918.488 & 10 \\
Std. Predicted Value & -.891 & 1.902 & .000 & 1.000 & 10 \\
Std. Residual & -1.232 & 1.343 & .000 & .745 & 10 \\
\hline
\end{tabular}

a. Dependent Variable: Funding

Fiscal Year 2007

Descriptive Statistics

\begin{tabular}{|l|r|r|r|}
\hline & \multicolumn{1}{|c|}{ Mean } & Std. Deviation & $\mathrm{N}$ \\
\hline Funding & 854633.70 & 552732.663 & 10 \\
Population & 30157989.50 & 17803760.522 & 10 \\
Zone1_Counties & 107.00 & 103.109 & 10 \\
Zone2_Counties & 103.60 & 78.032 & 10 \\
Zone3_Counties & 103.70 & 155.526 & 10 \\
\hline
\end{tabular}




\section{Correlations}

\begin{tabular}{|c|c|c|c|c|c|}
\hline & & Funding & Population & Zone1_Counties & Zone2_Counties \\
\hline & Funding & 1.000 & .653 & .533 & .748 \\
\hline & Population & .653 & 1.000 & -.035 & .602 \\
\hline $\begin{array}{l}\text { Pearson } \\
\text { Correlation }\end{array}$ & Zone1_Counties & .533 & -.035 & 1.000 & .511 \\
\hline & Zone2_Counties & .748 & .602 & .511 & 1.000 \\
\hline & Zone3_Counties & .104 & .549 & -.298 & .470 \\
\hline & Funding & . & .020 & .056 & .006 \\
\hline & Population & .020 & & .462 & .033 \\
\hline Sig. (1-tailed) & Zone1_Counties & .056 & .462 & & .066 \\
\hline & Zone2_Counties & .006 & .033 & .066 & . \\
\hline & Zone3_Counties & .387 & .050 & 201 & .085 \\
\hline & Funding & 10 & 10 & 10 & 10 \\
\hline & Population & 10 & 10 & 10 & 10 \\
\hline $\mathrm{N}$ & Zone1_Counties & 10 & 10 & 10 & 10 \\
\hline & Zone2_Counties & 10 & 10 & 10 & 10 \\
\hline & Zone3_Counties & 10 & 10 & 10 & 10 \\
\hline
\end{tabular}




\section{Correlations}

\begin{tabular}{|c|c|c|}
\hline & & Zone3_Counties \\
\hline \multirow{6}{*}{ Pearson Correlation } & $\begin{array}{l}\text { Funding } \\
\text { Population }\end{array}$ & $\begin{array}{l}.104 \\
.549\end{array}$ \\
\hline & Zone1_Counties & -.298 \\
\hline & Zone2_Counties & .470 \\
\hline & Zone3_Counties & 1.000 \\
\hline & Funding & .387 \\
\hline & Population & .050 \\
\hline \multirow[t]{5}{*}{ Sig. (1-tailed) } & Zone1_Counties & 201 \\
\hline & Zone2_Counties & .085 \\
\hline & Zone3_Counties & \\
\hline & Funding & 10 \\
\hline & Population & 10 \\
\hline \multirow[t]{3}{*}{$\mathrm{N}$} & Zone1_Counties & 10 \\
\hline & Zone2_Counties & 10 \\
\hline & Zone3_Counties & 10 \\
\hline
\end{tabular}

\section{Variables Entered/Removed $^{\mathrm{a}}$}

\begin{tabular}{|l|l|l|l|}
\hline Model & \multicolumn{1}{|c|}{$\begin{array}{c}\text { Variables } \\
\text { Entered }\end{array}$} & $\begin{array}{c}\text { Variables } \\
\text { Removed }\end{array}$ & Method \\
\hline 1 & $\begin{array}{l}\text { Zone3_Counties } \\
\text { Zone1_Counties } \\
\text { Zon_lation, } \\
\text { Zone2_Counties } \\
\text { bones }\end{array}$ & & \\
\hline
\end{tabular}

a. Dependent Variable: Funding

b. All requested variables entered. 
Model Summary

\begin{tabular}{|l|r|r|r|r|r|r|r|}
\hline Model & $\mathrm{R}$ & $\mathrm{R}$ Square & \multicolumn{1}{c|}{$\begin{array}{c}\text { Adjusted } \mathrm{R} \\
\text { Square }\end{array}$} & & & $\begin{array}{l}\text { Std. Error of } \\
\text { the Estimate }\end{array}$ & \multicolumn{3}{|c|}{ Change Statistics } \\
\cline { 5 - 8 } & & & & & $\begin{array}{l}\text { R Square } \\
\text { Change }\end{array}$ & $\begin{array}{c}\mathrm{F} \\
\text { Change }\end{array}$ & df1 \\
\hline 1 & $.895^{\mathrm{a}}$ & .801 & .642 & 330936.009 & .801 & 5.027 & 4 \\
\hline
\end{tabular}

Model Summary ${ }^{\mathrm{b}}$

\begin{tabular}{|l|r|rr|}
\hline \multirow{2}{*}{ Model } & \multicolumn{3}{|c|}{ Change Statistics } \\
\cline { 2 - 4 } & \multicolumn{2}{|c|}{ Sig. F Change } \\
\hline 1 & $5^{\mathrm{a}}$ & & .053 \\
\hline
\end{tabular}

a. Predictors: (Constant), Zone3_Counties, Zone1_Counties, Population, Zone2_Counties

b. Dependent Variable: Funding

ANOVA $^{\mathrm{a}}$

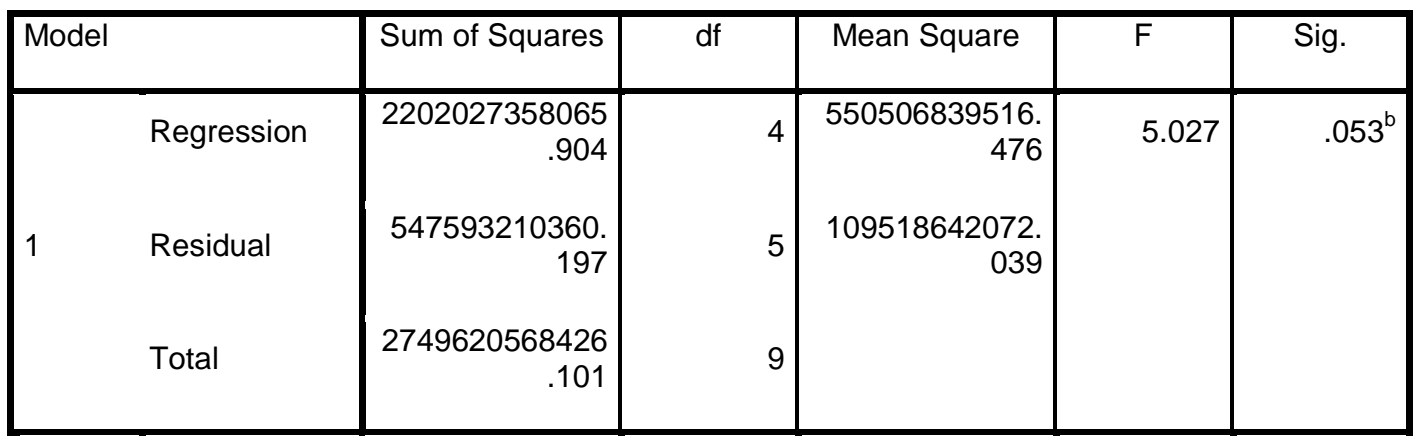

a. Dependent Variable: Funding

b. Predictors: (Constant), Zone3_Counties, Zone1_Counties, Population, Zone2_Counties 
Coefficients $^{\mathrm{a}}$

\begin{tabular}{|c|c|c|c|c|c|c|}
\hline \multirow{2}{*}{\multicolumn{2}{|c|}{ Model }} & \multicolumn{2}{|c|}{ Unstandardized Coefficients } & \multirow{2}{*}{$\begin{array}{c}\text { Standardized } \\
\text { Coefficients }\end{array}$} & \multirow[t]{2}{*}{$\mathrm{t}$} & \multirow[t]{2}{*}{ Sig. } \\
\hline & & $B$ & Std. Error & & & \\
\hline \multirow{5}{*}{1} & (Constant) & -12160.615 & 255901.401 & & -.048 & .964 \\
\hline & Population & .018 & .009 & .583 & 2.017 & .100 \\
\hline & Zone1_Counties & 1056.652 & 1892.408 & 197 & .558 & 601 \\
\hline & Zone2_Counties & 3363.119 & 3017.893 & 475 & 1.114 & 316 \\
\hline & Zone3_Counties & -1351.560 & 1142.608 & -.380 & -1.183 & .290 \\
\hline
\end{tabular}

\begin{tabular}{|l|r|r|r|r|r|}
\hline \multicolumn{2}{|c|}{ Model } & \multicolumn{3}{|c|}{ Correlations } & \multicolumn{2}{c|}{ Collinearity Statistics } \\
\cline { 2 - 6 } & Zero-order & Partial & \multicolumn{1}{c|}{ Part } & Tolerance & \multicolumn{1}{c|}{ VIF } \\
\hline (Constant) & & & & & \\
Population & .653 & .670 & .402 & .477 & 2.095 \\
1 & .533 & .242 & .111 & .320 & 3.129 \\
Zone1_Counties & .748 & .446 & .222 & .219 & 4.557 \\
& .104 & -.468 & -.236 & .385 & 2.595 \\
\hline
\end{tabular}

a. Dependent Variable: Funding

\section{Collinearity Diagnostics ${ }^{a}$}

\begin{tabular}{|c|c|c|c|c|c|c|}
\hline \multirow[t]{2}{*}{ Model } & \multirow[t]{2}{*}{ Dimension } & \multirow[t]{2}{*}{ Eigenvalue } & \multirow{2}{*}{$\begin{array}{l}\text { Condition } \\
\text { Index }\end{array}$} & \multicolumn{3}{|c|}{ Variance Proportions } \\
\hline & & & & (Constant) & Population & Zone1_Counties \\
\hline \multirow{5}{*}{1} & 1 & 3.834 & 1.000 & .01 & .01 & .01 \\
\hline & 2 & .768 & 2.234 & .00 & .00 & .08 \\
\hline & 3 & 241 & 3.991 & .31 & .06 & .09 \\
\hline & 4 & .117 & 5.736 & .34 & .43 & .07 \\
\hline & 5 & .041 & 9.729 & .34 & .50 & .75 \\
\hline
\end{tabular}


Collinearity Diagnostics ${ }^{a}$

\begin{tabular}{|c|c|c|c|}
\hline \multirow[t]{2}{*}{ Model } & \multirow[t]{2}{*}{ Dimension } & \multicolumn{2}{|c|}{ Variance Proportions } \\
\hline & & Zone2_Counties & Zone3_Counties \\
\hline \multirow{5}{*}{1} & 1 & .00 & .01 \\
\hline & 2 & .00 & .18 \\
\hline & 3 & .05 & .11 \\
\hline & 4 & .06 & .36 \\
\hline & 5 & .88 & .34 \\
\hline
\end{tabular}

a. Dependent Variable: Funding

Residuals Statistics ${ }^{a}$

\begin{tabular}{|l|r|r|r|r|r|}
\hline & \multicolumn{1}{|c|}{ Minimum } & Maximum & Mean & Std. Deviation & N \\
\hline Predicted Value & 364232.63 & 1841897.75 & 854633.70 & 494640.987 & 10 \\
Residual & -373561.813 & 435097.656 & .000 & 246665.137 & 10 \\
Std. Predicted Value & -.991 & 1.996 & .000 & 1.000 & 10 \\
Std. Residual & -1.129 & 1.315 & .000 & .745 & 10 \\
\hline
\end{tabular}

a. Dependent Variable: Funding

Fiscal Year 2008

Descriptive Statistics

\begin{tabular}{|l|r|r|r|}
\hline & \multicolumn{1}{|c|}{ Mean } & Std. Deviation & $\mathrm{N}$ \\
\hline Funding & 852642.10 & 536112.083 & 10 \\
Population & 30437484.60 & 17973469.468 & 10 \\
Zone1_Counties & 107.00 & 103.109 & 10 \\
Zone2_Counties & 103.60 & 78.032 & 10 \\
Zone3_Counties & 103.70 & 155.526 & 10 \\
\hline
\end{tabular}




\section{Correlations}

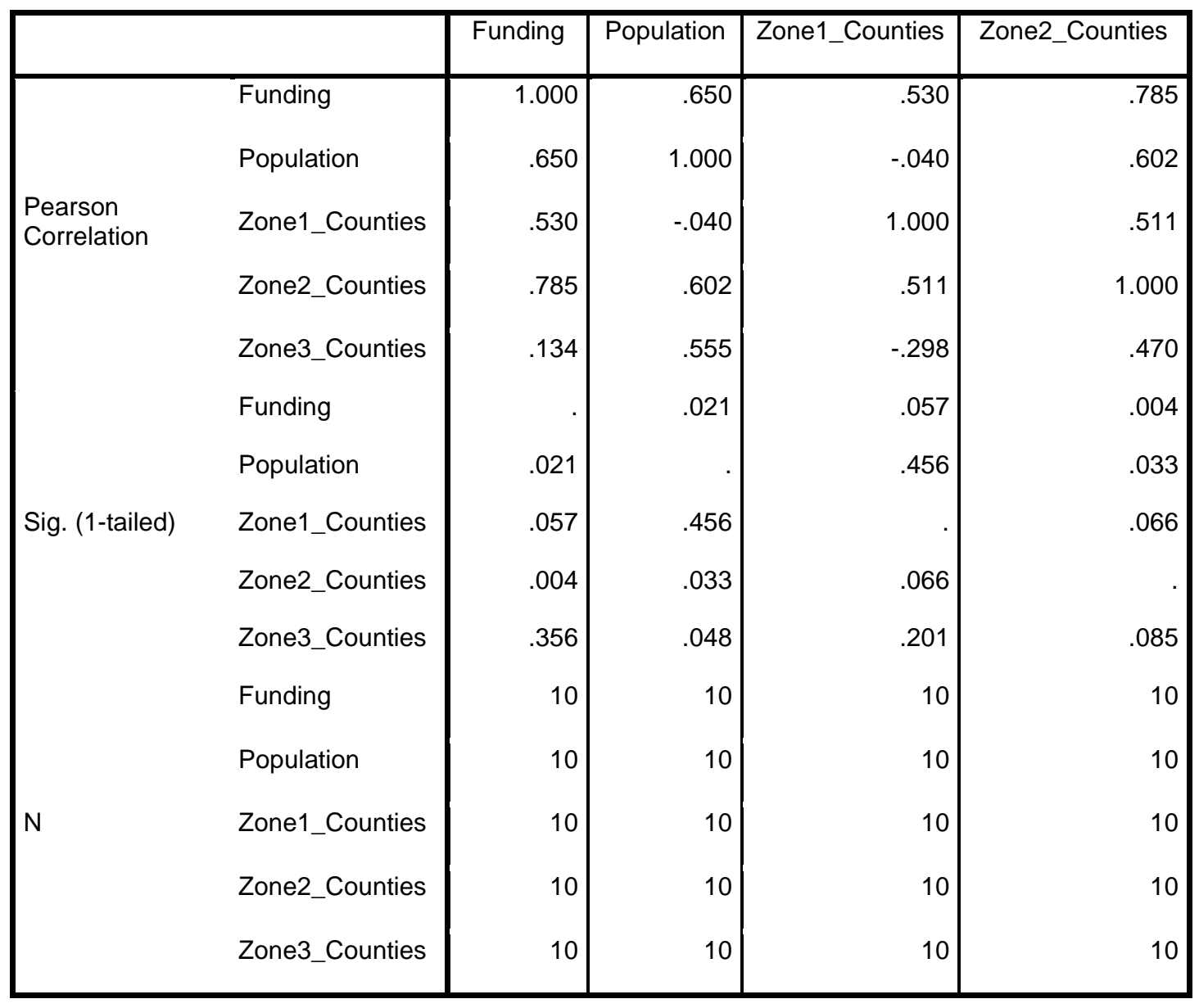




\section{Correlations}

\begin{tabular}{|c|c|c|}
\hline & & Zone3_Counties \\
\hline & Funding & .134 \\
\hline & Population & .555 \\
\hline Pearson Correlation & Zone1_Counties & -.298 \\
\hline & Zone2_Counties & .470 \\
\hline & Zone3_Counties & 1.000 \\
\hline & Funding & .356 \\
\hline & Population & .048 \\
\hline Sig. (1-tailed) & Zone1_Counties & .201 \\
\hline & Zone2_Counties & .085 \\
\hline & Zone3_Counties & \\
\hline & Funding & 10 \\
\hline & Population & 10 \\
\hline$N$ & Zone1_Counties & 10 \\
\hline & Zone2_Counties & 10 \\
\hline & Zone3_Counties & 10 \\
\hline
\end{tabular}

\section{Variables Entered/Removed $^{\mathrm{a}}$}

\begin{tabular}{|l|l|l|l|}
\hline Model & \multicolumn{1}{|c|}{$\begin{array}{c}\text { Variables } \\
\text { Entered }\end{array}$} & $\begin{array}{c}\text { Variables } \\
\text { Removed }\end{array}$ & Method \\
\hline 1 & $\begin{array}{l}\text { Zone3_Counties } \\
\text { Zone1_Counties } \\
\text { Population, } \\
\text { Zone2_Counties } \\
\mathrm{b}\end{array}$ & & \\
& & Enter \\
\hline
\end{tabular}

a. Dependent Variable: Funding

b. All requested variables entered. 
Model Summary

\begin{tabular}{|l|r|r|r|r|r|r|r|}
\hline Model & $\mathrm{R}$ & $\mathrm{R}$ Square & \multicolumn{1}{|c|}{$\begin{array}{c}\text { Adjusted } \mathrm{R} \\
\text { Square }\end{array}$} & & $\begin{array}{l}\text { Std. Error of } \\
\text { the Estimate }\end{array}$ & \multicolumn{3}{|c|}{ Change Statistics } \\
\cline { 5 - 8 } & & & & & $\begin{array}{l}\text { R Square } \\
\text { Change }\end{array}$ & F Change & df1 \\
\hline 1 & $.904^{\mathrm{a}}$ & .817 & .671 & 307429.314 & .817 & 5.592 & 4 \\
\hline
\end{tabular}

Model Summary ${ }^{\mathrm{b}}$

\begin{tabular}{|c|c|c|}
\hline \multirow[t]{2}{*}{ Model } & \multicolumn{2}{|c|}{ Change Statistics } \\
\hline & df2 & Sig. F Change \\
\hline 1 & 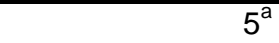 & .043 \\
\hline
\end{tabular}

a. Predictors: (Constant), Zone3_Counties, Zone1_Counties, Population, Zone2_Counties

b. Dependent Variable: Funding

ANOVA $^{\mathrm{a}}$

\begin{tabular}{|c|c|c|c|c|c|}
\hline Model & Sum of Squares & df & Mean Square & $\mathrm{F}$ & Sig. \\
\hline $\begin{array}{l}\text { Regression } \\
\text { Residual } \\
\text { Total }\end{array}$ & $\begin{array}{r}2114181570961 \\
.502 \\
\\
472563914653 . \\
399 \\
\\
2586745485614 \\
.900\end{array}$ & $\begin{array}{l}5 \\
9\end{array}$ & $\begin{array}{r}528545392740 \\
375 \\
\\
94512782930.6 \\
80\end{array}$ & 5.592 & $.043^{b}$ \\
\hline
\end{tabular}

a. Dependent Variable: Funding

b. Predictors: (Constant), Zone3_Counties, Zone1_Counties, Population, Zone2_Counties 
Coefficients $^{\mathrm{a}}$

\begin{tabular}{|c|c|c|c|c|c|c|}
\hline \multirow{2}{*}{\multicolumn{2}{|c|}{ Model }} & \multicolumn{2}{|c|}{ Unstandardized Coefficients } & \multirow{2}{*}{$\begin{array}{c}\begin{array}{c}\text { Standardized } \\
\text { Coefficients }\end{array} \\
\text { Beta }\end{array}$} & \multirow[t]{2}{*}{$\mathrm{t}$} & \multirow[t]{2}{*}{ Sig. } \\
\hline & & B & Std. Error & & & \\
\hline & (Constant) & 29529.058 & 238133.335 & & .124 & .906 \\
\hline & Population & .015 & .008 & .517 & 1.860 & .122 \\
\hline \multirow[t]{3}{*}{1} & Zone1_Counties & 685.219 & 1758.822 & 132 & .390 & .713 \\
\hline & Zone2_Counties & 4061.958 & 2801.899 & .591 & 1.450 & 207 \\
\hline & Zone3_Counties & -1351.650 & 1061.785 & -.392 & -1.273 & .259 \\
\hline
\end{tabular}

\begin{tabular}{|l|r|r|r|r|r|}
\hline \multirow{2}{*}{ Model } & \multicolumn{3}{|c|}{ Correlations } & \multicolumn{2}{c|}{ Collinearity Statistics } \\
\cline { 2 - 6 } & Zero-order & Partial & \multicolumn{1}{c|}{ Part } & Tolerance & \multicolumn{1}{c|}{ VIF } \\
\hline \multirow{2}{*}{ (Constant) } & .650 & .640 & .356 & .473 & 2.112 \\
Population & .530 & .172 & .074 & .319 & 3.132 \\
& .785 & .544 & .277 & .220 & 4.552 \\
Zone1_Counties & .134 & -.495 & -.243 & .385 & 2.597 \\
Zone2_Counties & & & & & \\
Zone3_Counties & & & & &
\end{tabular}

a. Dependent Variable: Funding

\section{Collinearity Diagnostics ${ }^{a}$}

\begin{tabular}{|c|c|c|c|c|c|c|}
\hline \multirow[t]{2}{*}{ Model } & \multirow[t]{2}{*}{ Dimension } & \multirow[t]{2}{*}{ Eigenvalue } & \multirow{2}{*}{$\begin{array}{l}\text { Condition } \\
\text { Index }\end{array}$} & \multicolumn{3}{|c|}{ Variance Proportions } \\
\hline & & & & (Constant) & Population & Zone1_Counties \\
\hline \multirow{5}{*}{1} & 1 & 3.834 & 1.000 & .01 & .01 & .01 \\
\hline & 2 & .769 & 2.233 & .00 & .00 & .08 \\
\hline & 3 & .241 & 3.992 & .31 & .06 & .09 \\
\hline & 4 & .116 & 5.759 & .34 & .43 & .07 \\
\hline & 5 & .040 & 9.732 & .34 & .50 & .75 \\
\hline
\end{tabular}


Collinearity Diagnostics ${ }^{a}$

\begin{tabular}{|c|c|c|c|}
\hline \multirow[t]{2}{*}{ Model } & \multirow[t]{2}{*}{ Dimension } & \multicolumn{2}{|c|}{ Variance Proportions } \\
\hline & & Zone2_Counties & Zone3_Counties \\
\hline \multirow{5}{*}{1} & 1 & .00 & .01 \\
\hline & 2 & .00 & .18 \\
\hline & 3 & .06 & .11 \\
\hline & 4 & .06 & .37 \\
\hline & 5 & .88 & .33 \\
\hline
\end{tabular}

a. Dependent Variable: Funding

Residuals Statistics ${ }^{a}$

\begin{tabular}{|l|r|r|r|r|r|}
\hline & \multicolumn{1}{|c|}{ Minimum } & Maximum & \multicolumn{1}{|c|}{ Mean } & Std. Deviation & \multicolumn{1}{|c|}{ N } \\
\hline Predicted Value & 409713.59 & 1791543.88 & 852642.10 & 484674.183 & 10 \\
Residual & -354721.719 & 437338.438 & .000 & 229144.281 & 10 \\
Std. Predicted Value & -.914 & 1.937 & .000 & 1.000 & 10 \\
Std. Residual & -1.154 & 1.423 & .000 & .745 & 10 \\
\hline
\end{tabular}

a. Dependent Variable: Funding 


\section{Appendix 2 State-Level SPSS Outputs}

Fiscal Year 2002

Descriptive Statistics

\begin{tabular}{|l|r|r|r|}
\hline & \multicolumn{1}{|c|}{ Mean } & Std. Deviation & $\mathrm{N}$ \\
\hline Funding & $\$ 162,281.19$ & $\$ 146,759.824$ & 51 \\
Population & 5643214.00 & 6336954.342 & 51 \\
Zone1_Counties & 20.98 & 25.064 & 51 \\
Zone2_Counties & 20.31 & 19.715 & 51 \\
Zone3_Counties & 20.33 & 37.109 & 51 \\
\hline
\end{tabular}

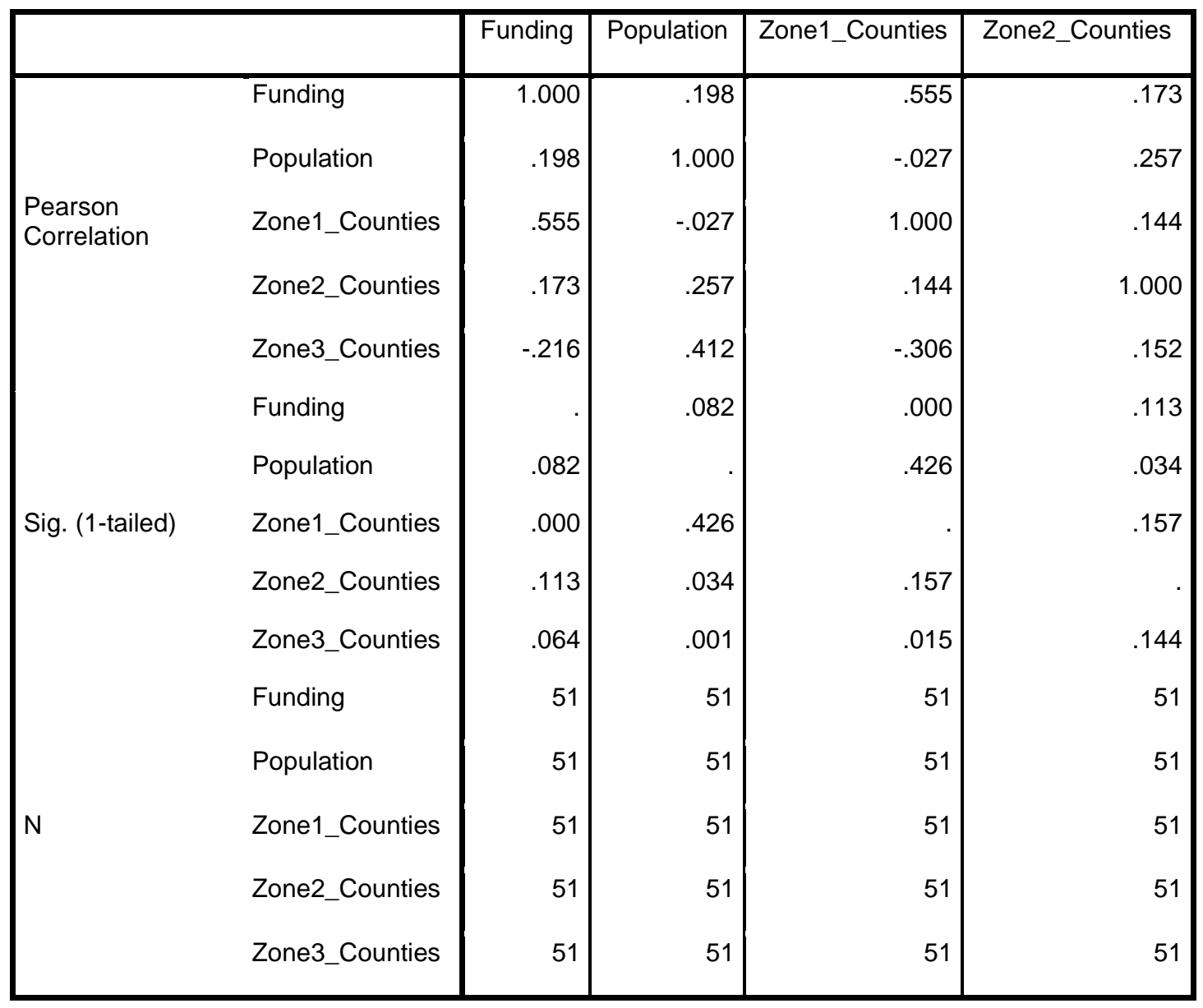




\section{Correlations}

\begin{tabular}{|c|c|c|}
\hline & & Zone3_Counties \\
\hline \multirow{6}{*}{ Pearson Correlation } & $\begin{array}{l}\text { Funding } \\
\text { Population }\end{array}$ & $\begin{array}{r}-.216 \\
.412\end{array}$ \\
\hline & Zone1_Counties & -.306 \\
\hline & Zone2_Counties & .152 \\
\hline & Zone3_Counties & 1.000 \\
\hline & Funding & .064 \\
\hline & Population & .001 \\
\hline \multirow[t]{5}{*}{ Sig. (1-tailed) } & Zone1_Counties & .015 \\
\hline & Zone2_Counties & .144 \\
\hline & Zone3_Counties & \\
\hline & Funding & 51 \\
\hline & Population & 51 \\
\hline \multirow[t]{3}{*}{$\mathrm{N}$} & Zone1_Counties & 51 \\
\hline & Zone2_Counties & 51 \\
\hline & Zone3_Counties & 51 \\
\hline
\end{tabular}

Variables Entered/Removed ${ }^{\mathrm{a}}$

\begin{tabular}{|l|l|l|l|}
\hline Model & \multicolumn{1}{|c|}{$\begin{array}{c}\text { Variables } \\
\text { Entered }\end{array}$} & $\begin{array}{c}\text { Variables } \\
\text { Removed }\end{array}$ & Method \\
\hline 1 & $\begin{array}{l}\text { Zone3_Counties } \\
\text { Zone2_Counties } \\
\text { Zone1_Counties } \\
\text { Population }\end{array}$ & & \\
\hline
\end{tabular}

a. Dependent Variable: Funding

b. All requested variables entered. 
Model Summary

\begin{tabular}{|c|c|c|c|c|c|c|c|}
\hline \multirow[t]{2}{*}{ Model } & \multirow[t]{2}{*}{$\mathrm{R}$} & \multirow{2}{*}{$\begin{array}{c}\mathrm{R} \\
\text { Square }\end{array}$} & \multirow{2}{*}{$\begin{array}{l}\text { Adjusted R } \\
\text { Square }\end{array}$} & \multirow{2}{*}{$\begin{array}{l}\text { Std. Error of the } \\
\text { Estimate }\end{array}$} & \multicolumn{3}{|c|}{ Change Statistics } \\
\hline & & & & & R Square Change & F Change & df1 \\
\hline 1 & $.617^{\mathrm{a}}$ & .380 & .326 & $\$ 120,441.957$ & .380 & 7.060 & 4 \\
\hline
\end{tabular}

Model Summary ${ }^{b}$

\begin{tabular}{|l|r|r|r|}
\hline \multirow{2}{*}{ Model } & \multicolumn{2}{|c|}{ Change Statistics } & \multicolumn{2}{|c|}{ Durbin-Watson } \\
\cline { 2 - 3 } & df2 & Sig. F Change & \\
\hline 1 & $46^{\mathrm{a}}$ & .000 & 1.866 \\
\hline
\end{tabular}

a. Predictors: (Constant), Zone3_Counties, Zone2_Counties, Zone1_Counties, Population

b. Dependent Variable: Funding

ANOVA $^{\mathrm{a}}$

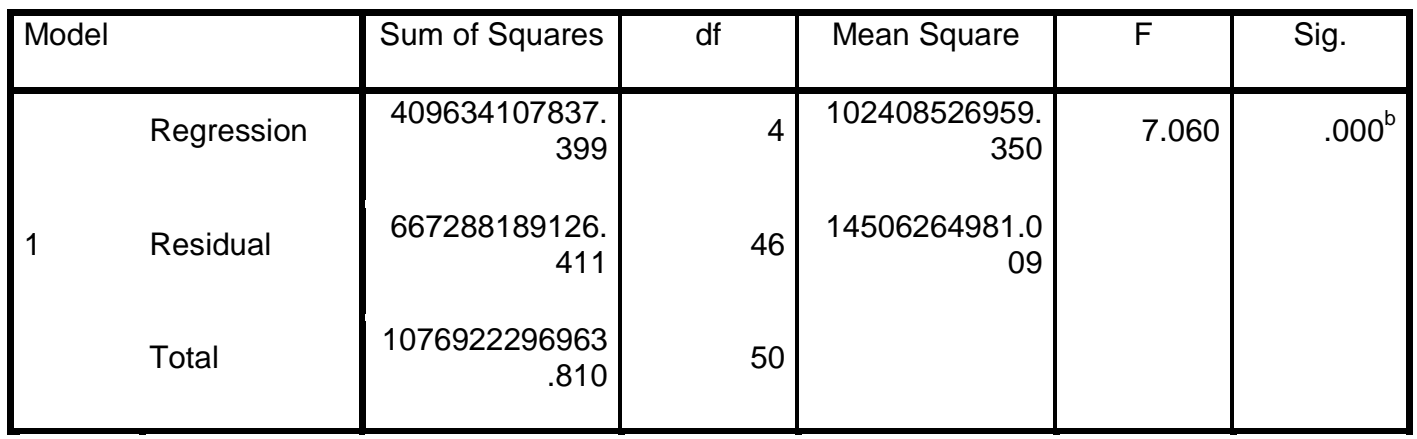

a. Dependent Variable: Funding

b. Predictors: (Constant), Zone3_Counties, Zone2_Counties, Zone1_Counties, Population 
Coefficients $^{\mathrm{a}}$

\begin{tabular}{|c|c|c|c|c|c|c|}
\hline \multirow{2}{*}{\multicolumn{2}{|c|}{ Model }} & \multicolumn{2}{|c|}{ Unstandardized Coefficients } & \multirow{2}{*}{$\begin{array}{c}\text { Standardized } \\
\text { Coefficients }\end{array}$} & \multirow[t]{2}{*}{$\mathrm{t}$} & \multirow[t]{2}{*}{ Sig. } \\
\hline & & B & Std. Error & & & \\
\hline \multirow{5}{*}{1} & (Constant) & 71569.646 & 30444.489 & & 2.351 & .023 \\
\hline & Population & .006 & .003 & 272 & 2.078 & .043 \\
\hline & Zone1_Counties & 2914.402 & 730.729 & .498 & 3.988 & .000 \\
\hline & Zone2_Counties & 438.952 & 910.649 & .059 & .482 & .632 \\
\hline & Zone3_Counties & -731.776 & 535.428 & -.185 & -1.367 & 178 \\
\hline
\end{tabular}

Coefficients $^{a}$

\begin{tabular}{|l|r|r|r|r|r|}
\hline \multirow{2}{*}{ Model } & \multicolumn{3}{|c|}{ Correlations } & \multicolumn{3}{c|}{ Collinearity Statistics } \\
\cline { 2 - 6 } & Zero-order & Partial & Part & Tolerance & \multicolumn{1}{c|}{ VIF } \\
\hline \multirow{2}{*}{ (Constant) } & & & & & \\
Population & .198 & .293 & .241 & .787 & 1.270 \\
& .555 & .507 & .463 & .865 & 1.156 \\
Zone1_Counties & .173 & .071 & .056 & .900 & 1.111 \\
Zone2_Counties & -.216 & -.198 & -.159 & .735 & 1.361 \\
Zone3_Counties & & & & &
\end{tabular}

a. Dependent Variable: Funding

Collinearity Diagnostics ${ }^{a}$

\begin{tabular}{|c|c|c|c|c|c|c|}
\hline \multirow[t]{2}{*}{ Model } & \multirow[t]{2}{*}{ Dimension } & \multirow[t]{2}{*}{ Eigenvalue } & \multirow{2}{*}{$\begin{array}{l}\text { Condition } \\
\text { Index }\end{array}$} & \multicolumn{3}{|c|}{ Variance Proportions } \\
\hline & & & & (Constant) & Population & Zone1_Counties \\
\hline \multirow{5}{*}{1} & 1 & 3.139 & 1.000 & .03 & .03 & .02 \\
\hline & 2 & .947 & 1.820 & .01 & .03 & .23 \\
\hline & 3 & .359 & 2.955 & .00 & .14 & .25 \\
\hline & 4 & .329 & 3.090 & .03 & .78 & .12 \\
\hline & 5 & .226 & 3.730 & .94 & .02 & .38 \\
\hline
\end{tabular}


Collinearity Diagnostics ${ }^{a}$

\begin{tabular}{|c|c|c|c|}
\hline \multirow[t]{2}{*}{ Model } & \multirow[t]{2}{*}{ Dimension } & \multicolumn{2}{|c|}{ Variance Proportions } \\
\hline & & Zone2_Counties & Zone3_Counties \\
\hline \multirow{5}{*}{1} & 1 & .03 & .02 \\
\hline & 2 & .00 & .29 \\
\hline & 3 & .82 & .04 \\
\hline & 4 & .01 & .52 \\
\hline & 5 & .14 & .13 \\
\hline
\end{tabular}

a. Dependent Variable: Funding

Residuals Statistics ${ }^{a}$

\begin{tabular}{|l|r|r|r|r|r|}
\hline & \multicolumn{1}{|c|}{ Minimum } & Maximum & Mean & Std. Deviation & $\mathrm{N}$ \\
\hline Predicted Value & $\$ 38,927.50$ & $\$ 378,537.72$ & $\$ 162,281.19$ & $\$ 90,513.436$ & 51 \\
Residual & $-\$ 213,496.234$ & $\$ 326,022.219$ & $\$ 0.000$ & $\$ 115,523.867$ & 51 \\
Std. Predicted Value & -1.363 & 2.389 & .000 & 1.000 & 51 \\
Std. Residual & -1.773 & 2.707 & .000 & .959 & 51 \\
\hline
\end{tabular}

a. Dependent Variable: Funding

Fiscal Year 2003

Descriptive Statistics

\begin{tabular}{|l|r|r|r|}
\hline & \multicolumn{1}{|c|}{ Mean } & Std. Deviation & $\mathrm{N}$ \\
\hline Funding & $\$ 167,866.15$ & $\$ 176,997.992$ & 51 \\
Population & 5692674.86 & 6403800.433 & 51 \\
Zone1_Counties & 20.98 & 25.064 & 51 \\
Zone2_Counties & 20.31 & 19.715 & 51 \\
Zone3_Counties & 20.33 & 37.109 & 51 \\
\hline
\end{tabular}




\section{Correlations}

\begin{tabular}{|c|c|c|c|c|c|}
\hline & & Funding & Population & Zone1_Counties & Zone2_Counties \\
\hline & Funding & 1.000 & .091 & .428 & .259 \\
\hline & Population & .091 & 1.000 & -.029 & .257 \\
\hline Pearson & Zone1 Counties & .428 & -.029 & 1.000 & .144 \\
\hline & Zone2 Counties & .259 & .257 & .144 & 1.000 \\
\hline & Zone3_Counties & -.235 & .415 & -.306 & .152 \\
\hline & Funding & & .262 & .001 & .033 \\
\hline & Population & .262 & & .419 & .034 \\
\hline Sig. (1-tailed) & Zone1_Counties & .001 & .419 & & .157 \\
\hline & Zone2_Counties & .033 & .034 & 157 & \\
\hline & Zone3_Counties & .049 & .001 & .015 & .144 \\
\hline & Funding & 51 & 51 & 51 & 51 \\
\hline & Population & 51 & 51 & 51 & 51 \\
\hline $\mathrm{N}$ & Zone1_Counties & 51 & 51 & 51 & 51 \\
\hline & Zone2_Counties & 51 & 51 & 51 & 51 \\
\hline & Zone3_Counties & 51 & 51 & 51 & 51 \\
\hline
\end{tabular}




\section{Correlations}

\begin{tabular}{|c|c|c|}
\hline & & Zone3_Counties \\
\hline \multirow{6}{*}{ Pearson Correlation } & $\begin{array}{l}\text { Funding } \\
\text { Population }\end{array}$ & $\begin{array}{r}-.235 \\
.415\end{array}$ \\
\hline & Zone1_Counties & -.306 \\
\hline & Zone2_Counties & .152 \\
\hline & Zone3_Counties & 1.000 \\
\hline & Funding & .049 \\
\hline & Population & .001 \\
\hline \multirow[t]{5}{*}{ Sig. (1-tailed) } & Zone1_Counties & .015 \\
\hline & Zone2_Counties & .144 \\
\hline & Zone3_Counties & \\
\hline & Funding & 51 \\
\hline & Population & 51 \\
\hline \multirow[t]{3}{*}{$\mathrm{N}$} & Zone1_Counties & 51 \\
\hline & Zone2_Counties & 51 \\
\hline & Zone3_Counties & 51 \\
\hline
\end{tabular}

Variables Entered/Removed ${ }^{\mathrm{a}}$

\begin{tabular}{|l|l|l|l|}
\hline Model & \multicolumn{1}{|c|}{$\begin{array}{c}\text { Variables } \\
\text { Entered }\end{array}$} & $\begin{array}{c}\text { Variables } \\
\text { Removed }\end{array}$ & Method \\
\hline 1 & $\begin{array}{l}\text { Zone3_Counties } \\
\text { Zone2_Counties } \\
\text { Zone1_Counties } \\
\text { Population }\end{array}$ & & \\
\hline
\end{tabular}

a. Dependent Variable: Funding

b. All requested variables entered. 
Model Summary

\begin{tabular}{|c|c|c|c|c|c|c|c|}
\hline \multirow[t]{2}{*}{ Model } & \multirow[t]{2}{*}{$\mathrm{R}$} & \multirow{2}{*}{$\begin{array}{c}\mathrm{R} \\
\text { Square }\end{array}$} & \multirow{2}{*}{$\begin{array}{l}\text { Adjusted R } \\
\text { Square }\end{array}$} & \multirow{2}{*}{$\begin{array}{l}\text { Std. Error of } \\
\text { the Estimate }\end{array}$} & \multicolumn{3}{|c|}{ Change Statistics } \\
\hline & & & & & R Square Change & F Change & df1 \\
\hline 1 & $.512^{\mathrm{a}}$ & .262 & .198 & $\$ 158,556.617$ & 262 & 4.077 & 4 \\
\hline
\end{tabular}

Model Summary ${ }^{\text {b }}$

\begin{tabular}{|l|r|r|r|}
\hline \multirow{2}{*}{ Model } & \multicolumn{2}{|c|}{ Change Statistics } & \multirow{2}{*}{ Durbin-Watson } \\
\cline { 2 - 3 } & df2 & Sig. F Change & \\
\hline 1 & $46^{\mathrm{a}}$ & .007 & 1.682 \\
\hline
\end{tabular}

a. Predictors: (Constant), Zone3_Counties, Zone2_Counties, Zone1_Counties, Population

b. Dependent Variable: Funding

ANOVA $^{\mathrm{a}}$

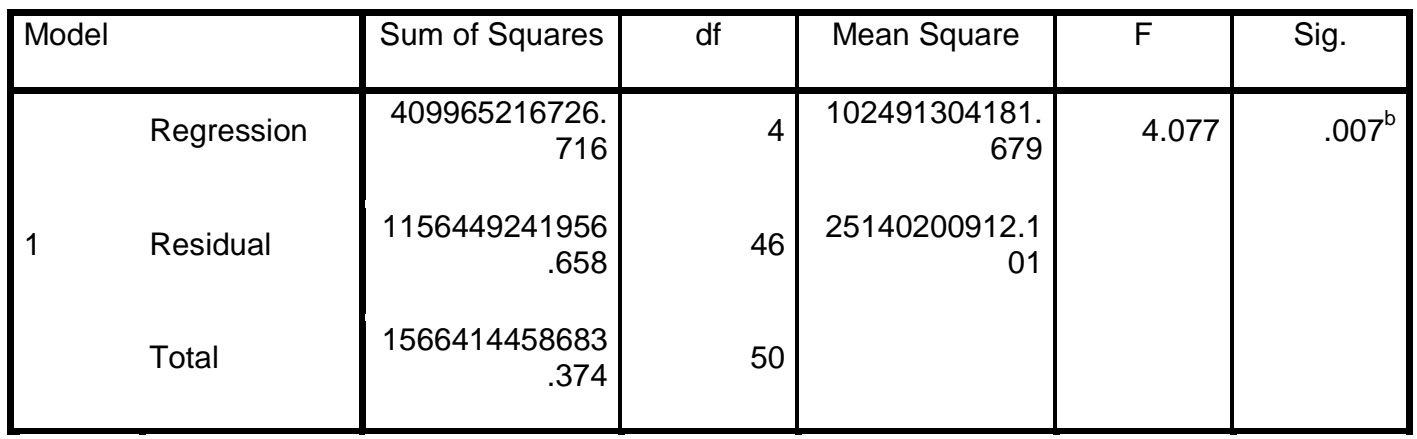

a. Dependent Variable: Funding

b. Predictors: (Constant), Zone3_Counties, Zone2_Counties, Zone1_Counties, Population 
Coefficients $^{\mathrm{a}}$

\begin{tabular}{|c|c|c|c|c|c|c|}
\hline \multirow{2}{*}{\multicolumn{2}{|c|}{ Model }} & \multicolumn{2}{|c|}{ Unstandardized Coefficients } & \multirow{2}{*}{$\begin{array}{c}\text { Standardized } \\
\text { Coefficients }\end{array}$} & \multirow[t]{2}{*}{$\mathrm{t}$} & \multirow[t]{2}{*}{ Sig. } \\
\hline & & $B$ & Std. Error & & & \\
\hline \multirow{5}{*}{1} & (Constant) & 79939.658 & 40074.368 & & 1.995 & .052 \\
\hline & Population & .004 & .004 & 140 & .977 & .334 \\
\hline & Zone1_Counties & 2355.591 & 961.867 & .334 & 2.449 & .018 \\
\hline & Zone2_Counties & 1875.643 & 1198.759 & 209 & 1.565 & .125 \\
\hline & Zone3_Counties & -1060.819 & 705.735 & -.222 & -1.503 & 140 \\
\hline
\end{tabular}

\begin{tabular}{|l|r|r|r|r|r|}
\hline \multirow{2}{*}{ Model } & \multicolumn{3}{|c|}{ Correlations } & \multicolumn{2}{c|}{ Collinearity Statistics } \\
\cline { 2 - 6 } & \multicolumn{1}{|c|}{ Zero-order } & Partial & Part & Tolerance & \multicolumn{1}{c|}{ VIF } \\
\hline (Constant) & .091 & .143 & .124 & .785 & 1.273 \\
Population & .428 & .340 & .310 & .865 & 1.156 \\
Zone1_Counties & .259 & .225 & .198 & .900 & 1.111 \\
Zone2_Counties & -.235 & -.216 & -.190 & .733 & 1.364 \\
Zone3_Counties & & & & & \\
\hline
\end{tabular}

a. Dependent Variable: Funding

Collinearity Diagnostics ${ }^{a}$

\begin{tabular}{|c|c|c|c|c|c|c|}
\hline \multirow[t]{2}{*}{ Model } & \multirow[t]{2}{*}{ Dimension } & \multirow[t]{2}{*}{ Eigenvalue } & \multirow{2}{*}{$\begin{array}{l}\text { Condition } \\
\text { Index }\end{array}$} & \multicolumn{3}{|c|}{ Variance Proportions } \\
\hline & & & & (Constant) & Population & Zone1_Counties \\
\hline \multirow{5}{*}{1} & 1 & 3.138 & 1.000 & .03 & .03 & .02 \\
\hline & 2 & .948 & 1.819 & .01 & .03 & .23 \\
\hline & 3 & .359 & 2.955 & .00 & .14 & .25 \\
\hline & 4 & .328 & 3.094 & .03 & .78 & .11 \\
\hline & 5 & 226 & 3.729 & .94 & .02 & .39 \\
\hline
\end{tabular}


Collinearity Diagnostics ${ }^{a}$

\begin{tabular}{|c|c|c|c|}
\hline \multirow[t]{2}{*}{ Model } & \multirow[t]{2}{*}{ Dimension } & \multicolumn{2}{|c|}{ Variance Proportions } \\
\hline & & Zone2_Counties & Zone3_Counties \\
\hline \multirow{5}{*}{1} & 1 & .03 & .02 \\
\hline & 2 & .00 & .29 \\
\hline & 3 & .82 & .04 \\
\hline & 4 & .00 & .52 \\
\hline & 5 & .14 & .13 \\
\hline
\end{tabular}

a. Dependent Variable: Funding

Residuals Statistics ${ }^{a}$

\begin{tabular}{|l|r|r|r|r|r|}
\hline & \multicolumn{1}{|c|}{ Minimum } & Maximum & Mean & Std. Deviation & N \\
\hline Predicted Value & $\$ 10,157.62$ & $\$ 337,951.66$ & $\$ 167,866.15$ & $\$ 90,550.010$ & 51 \\
Residual & $-\$ 273,889.281$ & $\$ 732,177.000$ & $-\$ 0.000$ & $\$ 152,082.165$ & 51 \\
Std. Predicted Value & -1.742 & 1.878 & .000 & 1.000 & 51 \\
Std. Residual & -1.727 & 4.618 & .000 & .959 & 51 \\
\hline
\end{tabular}

a. Dependent Variable: Funding

Fiscal Year 2004

Descriptive Statistics

\begin{tabular}{|l|r|r|r|}
\hline & \multicolumn{1}{|c|}{ Mean } & Std. Deviation & $\mathrm{N}$ \\
\hline Funding & $\$ 161,726.76$ & $\$ 148,729.322$ & 51 \\
Population & 5746253.41 & 6468158.823 & 51 \\
Zone1_Counties & 20.98 & 25.064 & 51 \\
Zone2_Counties & 20.31 & 19.715 & 51 \\
Zone3_Counties & 20.33 & 37.109 & 51 \\
\hline
\end{tabular}




\section{Correlations}

\begin{tabular}{|c|c|c|c|c|c|}
\hline & & Funding & Population & Zone1_Counties & Zone2_Counties \\
\hline & Funding & 1.000 & .183 & .464 & .320 \\
\hline & Population & .183 & 1.000 & -.032 & .257 \\
\hline \multirow{5}{*}{$\begin{array}{l}\text { Pearson } \\
\text { Correlation }\end{array}$} & Zone1_Counties & .464 & -.032 & 1.000 & .144 \\
\hline & Zone2_Counties & .320 & 257 & .144 & 1.000 \\
\hline & Zone3_Counties & -.252 & .419 & -.306 & .152 \\
\hline & Funding & & .099 & .000 & .011 \\
\hline & Population & .099 & & .412 & .034 \\
\hline \multirow[t]{5}{*}{ Sig. (1-tailed) } & Zone1_Counties & .000 & 412 & & .157 \\
\hline & Zone2_Counties & .011 & .034 & 157 & \\
\hline & Zone3_Counties & .037 & .001 & .015 & .144 \\
\hline & Funding & 51 & 51 & 51 & 51 \\
\hline & Population & 51 & 51 & 51 & 51 \\
\hline \multirow[t]{3}{*}{ N } & Zone1_Counties & 51 & 51 & 51 & 51 \\
\hline & Zone2_Counties & 51 & 51 & 51 & 51 \\
\hline & Zone3_Counties & 51 & 51 & 51 & 51 \\
\hline
\end{tabular}




\section{Correlations}

\begin{tabular}{|c|c|c|}
\hline & & Zone3_Counties \\
\hline \multirow{6}{*}{ Pearson Correlation } & $\begin{array}{l}\text { Funding } \\
\text { Population }\end{array}$ & $\begin{array}{r}-.252 \\
.419\end{array}$ \\
\hline & Zone1_Counties & -.306 \\
\hline & Zone2_Counties & .152 \\
\hline & Zone3_Counties & 1.000 \\
\hline & Funding & .037 \\
\hline & Population & .001 \\
\hline \multirow[t]{5}{*}{ Sig. (1-tailed) } & Zone1_Counties & 015 \\
\hline & Zone2_Counties & .144 \\
\hline & Zone3_Counties & \\
\hline & Funding & 51 \\
\hline & Population & 51 \\
\hline \multirow[t]{3}{*}{$\mathrm{N}$} & Zone1_Counties & 51 \\
\hline & Zone2_Counties & 51 \\
\hline & Zone3_Counties & 51 \\
\hline
\end{tabular}

\section{Variables Entered/Removed $^{\text {a }}$}

\begin{tabular}{|l|l|l|l|}
\hline Model & $\begin{array}{c}\text { Variables } \\
\text { Entered }\end{array}$ & $\begin{array}{c}\text { Variables } \\
\text { Removed }\end{array}$ & Method \\
\hline 1 & $\begin{array}{l}\text { Zone3_Counties } \\
\text { Zone2_Counties } \\
\text { Zone1_Counties } \\
\text { Population }\end{array}$ & & \\
\hline
\end{tabular}

a. Dependent Variable: Funding

b. All requested variables entered. 
Model Summary

\begin{tabular}{|c|c|c|c|c|c|c|c|}
\hline \multirow[t]{2}{*}{ Model } & \multirow[t]{2}{*}{$\mathrm{R}$} & \multirow{2}{*}{$\begin{array}{c}\mathrm{R} \\
\text { Square }\end{array}$} & \multirow{2}{*}{$\begin{array}{l}\text { Adjusted R } \\
\text { Square }\end{array}$} & \multirow{2}{*}{$\begin{array}{l}\text { Std. Error of the } \\
\text { Estimate }\end{array}$} & \multicolumn{3}{|c|}{ Change Statistics } \\
\hline & & & & & R Square Change & F Change & df1 \\
\hline 1 & $.600^{\mathrm{a}}$ & .360 & .305 & $\$ 124,019.635$ & .360 & 6.477 & 4 \\
\hline
\end{tabular}

Model Summary

\begin{tabular}{|c|c|c|c|}
\hline \multirow[t]{2}{*}{ Model } & \multicolumn{2}{|c|}{ Change Statistics } & \multirow[t]{2}{*}{ Durbin-Watson } \\
\hline & df2 & Sig. F Change & \\
\hline 1 & $46^{a}$ & .000 & 1.741 \\
\hline
\end{tabular}

a. Predictors: (Constant), Zone3_Counties, Zone2_Counties, Zone1_Counties, Population

b. Dependent Variable: Funding

ANOVA $^{\mathrm{a}}$

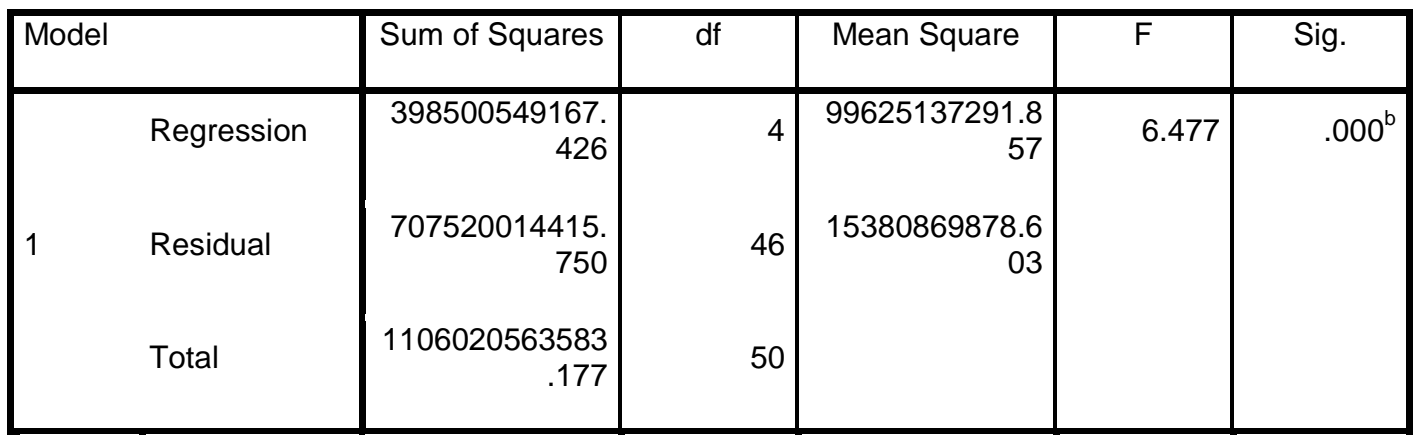

a. Dependent Variable: Funding

b. Predictors: (Constant), Zone3_Counties, Zone2_Counties, Zone1_Counties, Population 
Coefficients $^{\mathrm{a}}$

\begin{tabular}{|c|c|c|c|c|c|c|}
\hline \multirow{2}{*}{\multicolumn{2}{|c|}{ Model }} & \multicolumn{2}{|c|}{ Unstandardized Coefficients } & \multirow{2}{*}{$\begin{array}{c}\text { Standardized } \\
\text { Coefficients }\end{array}$} & \multirow[t]{2}{*}{$\mathrm{t}$} & \multirow[t]{2}{*}{ Sig. } \\
\hline & & B & Std. Error & & & \\
\hline \multirow{5}{*}{1} & (Constant) & 70501.641 & 31345.159 & & 2.249 & .029 \\
\hline & Population & .006 & .003 & .251 & 1.880 & .066 \\
\hline & Zone1_Counties & 2067.018 & 752.276 & .348 & 2.748 & .009 \\
\hline & Zone2_Counties & 1882.810 & 937.610 & .250 & 2.008 & .051 \\
\hline & Zone3_Counties & -1155.965 & 552.917 & -.288 & -2.091 & .042 \\
\hline
\end{tabular}

Coefficients $^{\mathrm{a}}$

\begin{tabular}{|r|r|r|r|r|r|}
\hline Model & \multicolumn{3}{|c|}{ Correlations } & \multicolumn{2}{c|}{ Collinearity Statistics } \\
\cline { 2 - 6 } & Zero-order & Partial & \multicolumn{1}{c|}{ Part } & Tolerance & \multicolumn{1}{c|}{ VIF } \\
\hline \multirow{2}{*}{ (Constant) } & & & & & \\
Population & .183 & .267 & .222 & .783 & 1.278 \\
& .464 & .375 & .324 & .865 & 1.156 \\
Zone1_Counties & .320 & .284 & .237 & .900 & 1.111 \\
Zone2_Counties & -.252 & -.295 & -.247 & .731 & 1.369 \\
\hline & Zone3_Counties & & & &
\end{tabular}

a. Dependent Variable: Funding

\section{Collinearity Diagnostics ${ }^{a}$}

\begin{tabular}{|lr|r|r|r|r|r|}
\hline Model & Dimension & Eigenvalue & \multicolumn{1}{c|}{$\begin{array}{c}\text { Condition } \\
\text { Index }\end{array}$} & \multicolumn{3}{|c|}{ Variance Proportions } \\
\cline { 4 - 6 } & & & & (Constant) & Population & Zone1_Counties \\
\hline & & 3.138 & 1.000 & .03 & .03 & .02 \\
& .950 & 1.818 & .01 & .03 & .23 \\
& & .359 & 2.955 & .00 & .13 & .25 \\
1 & .327 & 3.100 & .03 & .79 & .11 \\
& & .226 & 3.729 & .94 & .02 & .39 \\
\hline
\end{tabular}


Collinearity Diagnostics ${ }^{a}$

\begin{tabular}{|c|c|c|c|}
\hline \multirow[t]{2}{*}{ Model } & \multirow[t]{2}{*}{ Dimension } & \multicolumn{2}{|c|}{ Variance Proportions } \\
\hline & & Zone2_Counties & Zone3_Counties \\
\hline \multirow{5}{*}{1} & 1 & .03 & .02 \\
\hline & 2 & .00 & .28 \\
\hline & 3 & .82 & .04 \\
\hline & 4 & .00 & .52 \\
\hline & 5 & .14 & .12 \\
\hline
\end{tabular}

a. Dependent Variable: Funding

Residuals Statistics ${ }^{\mathrm{a}}$

\begin{tabular}{|l|r|r|r|r|r|}
\hline & \multicolumn{1}{|c|}{ Minimum } & Maximum & Mean & Std. Deviation & $\mathrm{N}$ \\
\hline Predicted Value & $\$ 16,654.94$ & $\$ 336,623.19$ & $\$ 161,726.76$ & $\$ 89,274.918$ & 51 \\
Residual & $-\$ 232,150.297$ & $\$ 378,884.969$ & $\$ 0.000$ & $\$ 118,955.455$ & 51 \\
Std. Predicted Value & -1.625 & 1.959 & .000 & 1.000 & 51 \\
Std. Residual & -1.872 & 3.055 & .000 & .959 & 51 \\
\hline
\end{tabular}

a. Dependent Variable: Funding

Fiscal Year 2005

Descriptive Statistics

\begin{tabular}{|l|r|r|r|}
\hline & \multicolumn{1}{|c|}{ Mean } & Std. Deviation & $\mathrm{N}$ \\
\hline Funding & $\$ 170,222.35$ & $\$ 152,130.646$ & 51 \\
Population & 5799331.57 & 6526246.926 & 51 \\
Zone1_Counties & 20.98 & 25.064 & 51 \\
Zone2_Counties & 20.31 & 19.715 & 51 \\
Zone3_Counties & 20.33 & 37.109 & 51 \\
\hline
\end{tabular}




\section{Correlations}

\begin{tabular}{|c|c|c|c|c|c|}
\hline & & Funding & Population & Zone1_Counties & Zone2_Counties \\
\hline & Funding & 1.000 & .203 & .497 & .313 \\
\hline & Population & .203 & 1.000 & -.035 & .257 \\
\hline $\begin{array}{l}\text { Pearson } \\
\text { Correlation }\end{array}$ & Zone1_Counties & .497 & -.035 & 1.000 & .144 \\
\hline & Zone2_Counties & .313 & .257 & .144 & 1.000 \\
\hline & Zone3_Counties & -.291 & .423 & -.306 & .152 \\
\hline & Funding & . & .077 & .000 & .013 \\
\hline & Population & .077 & & .405 & .034 \\
\hline Sig. (1-tailed) & Zone1_Counties & .000 & .405 & & .157 \\
\hline & Zone2_Counties & .013 & .034 & .157 & . \\
\hline & Zone3_Counties & .019 & .001 & .015 & .144 \\
\hline & Funding & 51 & 51 & 51 & 51 \\
\hline & Population & 51 & 51 & 51 & 51 \\
\hline $\mathrm{N}$ & Zone1_Counties & 51 & 51 & 51 & 51 \\
\hline & Zone2_Counties & 51 & 51 & 51 & 51 \\
\hline & Zone3_Counties & 51 & 51 & 51 & 51 \\
\hline
\end{tabular}




\section{Correlations}

\begin{tabular}{|c|c|c|}
\hline & & Zone3_Counties \\
\hline \multirow{6}{*}{ Pearson Correlation } & $\begin{array}{l}\text { Funding } \\
\text { Population }\end{array}$ & $\begin{array}{r}-.291 \\
.423\end{array}$ \\
\hline & Zone1_Counties & -.306 \\
\hline & Zone2_Counties & .152 \\
\hline & Zone3_Counties & 1.000 \\
\hline & Funding & .019 \\
\hline & Population & .001 \\
\hline \multirow[t]{5}{*}{ Sig. (1-tailed) } & Zone1_Counties & .015 \\
\hline & Zone2_Counties & .144 \\
\hline & Zone3_Counties & \\
\hline & Funding & 51 \\
\hline & Population & 51 \\
\hline \multirow[t]{3}{*}{$N$} & Zone1_Counties & 51 \\
\hline & Zone2_Counties & 51 \\
\hline & Zone3_Counties & 51 \\
\hline
\end{tabular}

Variables Entered/Removed ${ }^{\mathrm{a}}$

\begin{tabular}{|l|l|l|l|}
\hline Model & \multicolumn{1}{|c|}{$\begin{array}{c}\text { Variables } \\
\text { Entered }\end{array}$} & $\begin{array}{c}\text { Variables } \\
\text { Removed }\end{array}$ & Method \\
\hline 1 & $\begin{array}{l}\text { Zone3_Counties } \\
\text { Zone2_Counties } \\
\text { Zone1_Counties } \\
\text { Population }\end{array}$ & & \\
\hline
\end{tabular}

a. Dependent Variable: Funding

b. All requested variables entered. 
Model Summary

\begin{tabular}{|c|c|c|c|c|c|c|c|}
\hline \multirow[t]{2}{*}{ Model } & \multirow[t]{2}{*}{$\mathrm{R}$} & \multirow{2}{*}{$\begin{array}{c}\mathrm{R} \\
\text { Square }\end{array}$} & \multirow{2}{*}{$\begin{array}{l}\text { Adjusted R } \\
\text { Square }\end{array}$} & \multirow{2}{*}{$\begin{array}{l}\text { Std. Error of } \\
\text { the Estimate }\end{array}$} & \multicolumn{3}{|c|}{ Change Statistics } \\
\hline & & & & & R Square Change & F Change & df1 \\
\hline 1 & $.646^{\mathrm{a}}$ & .417 & .367 & $\$ 121,066.374$ & .417 & 8.238 & 4 \\
\hline
\end{tabular}

Model Summary ${ }^{b}$

\begin{tabular}{|l|r|r|r|}
\hline \multirow{2}{*}{ Model } & \multicolumn{2}{|c|}{ Change Statistics } & \multirow{2}{*}{ Durbin-Watson } \\
\cline { 2 - 3 } & df2 & Sig. F Change & \\
\hline 1 & $46^{\mathrm{a}}$ & & .000 \\
\hline
\end{tabular}

a. Predictors: (Constant), Zone3_Counties, Zone2_Counties, Zone1_Counties, Population

b. Dependent Variable: Funding

ANOVA $^{\mathrm{a}}$

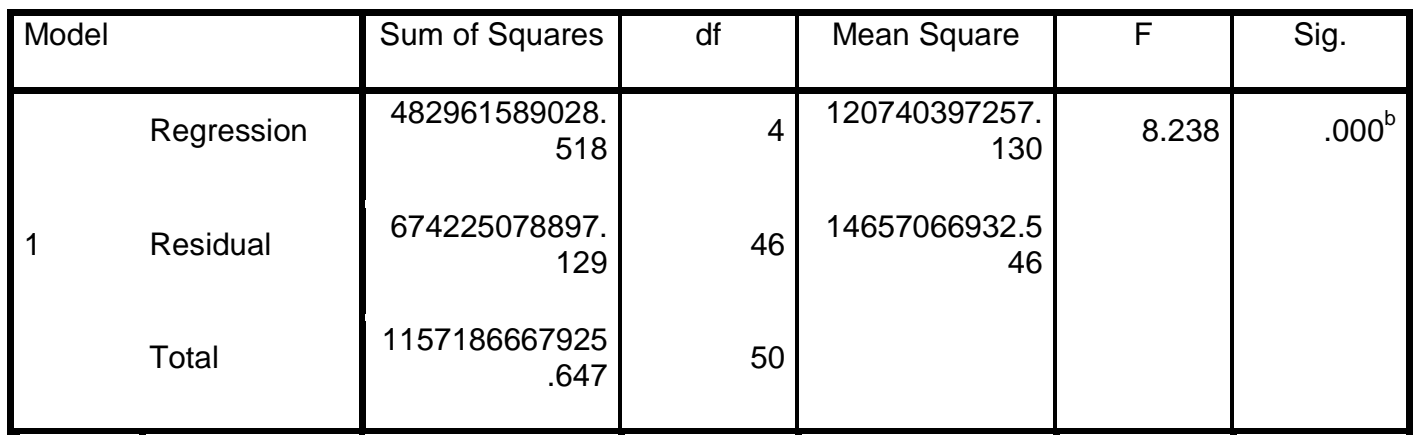

a. Dependent Variable: Funding

b. Predictors: (Constant), Zone3_Counties, Zone2_Counties, Zone1_Counties, Population 
Coefficients $^{\mathrm{a}}$

\begin{tabular}{|c|c|c|c|c|c|c|}
\hline \multirow{2}{*}{\multicolumn{2}{|c|}{ Model }} & \multicolumn{2}{|c|}{ Unstandardized Coefficients } & \multirow{2}{*}{$\begin{array}{c}\begin{array}{c}\text { Standardized } \\
\text { Coefficients }\end{array} \\
\text { Beta }\end{array}$} & \multirow[t]{2}{*}{$\mathrm{t}$} & \multirow[t]{2}{*}{ Sig. } \\
\hline & & B & Std. Error & & & \\
\hline \multirow{5}{*}{1} & (Constant) & 74238.646 & 30599.912 & & 2.426 & .019 \\
\hline & Population & .007 & .003 & .300 & 2.349 & .023 \\
\hline & Zone1_Counties & 2243.757 & 734.295 & 370 & 3.056 & .004 \\
\hline & Zone2_Counties & 1812.046 & 915.322 & 235 & 1.980 & .054 \\
\hline & Zone3_Counties & -1396.342 & 540.850 & -.341 & -2.582 & .013 \\
\hline
\end{tabular}

Coefficients $^{a}$

\begin{tabular}{|r|r|r|r|r|r|}
\hline \multirow{2}{*}{ Model } & \multicolumn{3}{|c|}{ Correlations } & \multicolumn{2}{c|}{ Collinearity Statistics } \\
\cline { 2 - 6 } & Zero-order & Partial & Part & Tolerance & \multicolumn{1}{c|}{ VIF } \\
\hline (Constant) & & & & & \\
Population & .203 & .327 & .264 & .779 & 1.284 \\
1 & .497 & .411 & .344 & .865 & 1.156 \\
Zone1_Counties & .313 & .280 & .223 & .900 & 1.111 \\
Zone2_Counties & -.291 & -.356 & -.291 & .728 & 1.374 \\
Zone3_Counties & & & & & \\
\hline
\end{tabular}

a. Dependent Variable: Funding

\section{Collinearity Diagnostics ${ }^{a}$}

\begin{tabular}{|c|c|c|c|c|c|c|}
\hline \multirow[t]{2}{*}{ Model } & \multirow[t]{2}{*}{ Dimension } & \multirow[t]{2}{*}{ Eigenvalue } & \multirow{2}{*}{$\begin{array}{l}\text { Condition } \\
\text { Index }\end{array}$} & \multicolumn{3}{|c|}{ Variance Proportions } \\
\hline & & & & (Constant) & Population & Zone1_Counties \\
\hline \multirow{5}{*}{1} & 1 & 3.139 & 1.000 & .03 & .03 & .02 \\
\hline & 2 & .951 & 1.816 & .01 & .03 & .23 \\
\hline & 3 & .359 & 2.956 & .00 & .12 & .26 \\
\hline & 4 & .324 & 3.110 & .02 & .80 & .10 \\
\hline & 5 & .226 & 3.730 & .94 & .02 & .39 \\
\hline
\end{tabular}


Collinearity Diagnostics ${ }^{a}$

\begin{tabular}{|c|c|c|c|}
\hline \multirow[t]{2}{*}{ Model } & \multirow[t]{2}{*}{ Dimension } & \multicolumn{2}{|c|}{ Variance Proportions } \\
\hline & & Zone2_Counties & Zone3_Counties \\
\hline \multirow{5}{*}{1} & 1 & .03 & .02 \\
\hline & 2 & .00 & .28 \\
\hline & 3 & .82 & .05 \\
\hline & 4 & .00 & .52 \\
\hline & 5 & .14 & .12 \\
\hline
\end{tabular}

a. Dependent Variable: Funding

Residuals Statistics ${ }^{a}$

\begin{tabular}{|l|r|r|r|r|r|}
\hline & Minimum & Maximum & Mean & Std. Deviation & $\mathrm{N}$ \\
\hline Predicted Value & $\$ 3,900.90$ & $\$ 362,112.66$ & $\$ 170,222.35$ & $\$ 98,281.391$ & 51 \\
Residual & $-\$ 251,330.500$ & $\$ 408,727.594$ & $-\$ 0.000$ & $\$ 116,122.787$ & 51 \\
Std. Predicted Value & -1.692 & 1.952 & .000 & 1.000 & 51 \\
Std. Residual & -2.076 & 3.376 & .000 & .959 & 51 \\
\hline
\end{tabular}

a. Dependent Variable: Funding

Fiscal Year 2006

Descriptive Statistics

\begin{tabular}{|l|r|r|r|}
\hline & \multicolumn{1}{|c|}{ Mean } & Std. Deviation & $\mathrm{N}$ \\
\hline Funding & $\$ 165,130.04$ & $\$ 135,930.662$ & 51 \\
Population & 5854768.86 & 6587479.061 & 51 \\
Zone1_Counties & 20.98 & 25.064 & 51 \\
Zone2_Counties & 20.31 & 19.715 & 51 \\
Zone3_Counties & 20.33 & 37.109 & 51 \\
\hline
\end{tabular}




\section{Correlations}

\begin{tabular}{|c|c|c|c|c|c|}
\hline & & Funding & Population & Zone1_Counties & Zone2_Counties \\
\hline & Funding & 1.000 & .272 & .399 & .305 \\
\hline & Population & .272 & 1.000 & -.037 & .259 \\
\hline $\begin{array}{l}\text { Pearson } \\
\text { Correlation }\end{array}$ & Zone1_Counties & .399 & -.037 & 1.000 & .144 \\
\hline & Zone2_Counties & .305 & .259 & .144 & 1.000 \\
\hline & Zone3_Counties & -.253 & .430 & -.306 & .152 \\
\hline & Funding & & .027 & .002 & .015 \\
\hline & Population & .027 & & .399 & .033 \\
\hline $\begin{array}{l}\text { Sig. (1- } \\
\text { tailed) }\end{array}$ & Zone1_Counties & .002 & .399 & & .157 \\
\hline & Zone2_Counties & .015 & .033 & .157 & . \\
\hline & Zone3_Counties & .036 & .001 & .015 & .144 \\
\hline & Funding & 51 & 51 & 51 & 51 \\
\hline & Population & 51 & 51 & 51 & 51 \\
\hline $\mathrm{N}$ & Zone1_Counties & 51 & 51 & 51 & 51 \\
\hline & Zone2_Counties & 51 & 51 & 51 & 51 \\
\hline & Zone3_Counties & 51 & 51 & 51 & 51 \\
\hline
\end{tabular}




\section{Correlations}

\begin{tabular}{|c|c|c|}
\hline & & Zone3_Counties \\
\hline \multirow{6}{*}{ Pearson Correlation } & $\begin{array}{l}\text { Funding } \\
\text { Population }\end{array}$ & $\begin{array}{r}-.253 \\
.430\end{array}$ \\
\hline & Zone1_Counties & -.306 \\
\hline & Zone2_Counties & .152 \\
\hline & Zone3_Counties & 1.000 \\
\hline & Funding & .036 \\
\hline & Population & .001 \\
\hline \multirow[t]{5}{*}{ Sig. (1-tailed) } & Zone1_Counties & .015 \\
\hline & Zone2_Counties & .144 \\
\hline & Zone3_Counties & \\
\hline & Funding & 51 \\
\hline & Population & 51 \\
\hline \multirow[t]{3}{*}{$\mathrm{N}$} & Zone1_Counties & 51 \\
\hline & Zone2_Counties & 51 \\
\hline & Zone3_Counties & 51 \\
\hline
\end{tabular}

Variables Entered/Removed ${ }^{\mathrm{a}}$

\begin{tabular}{|l|l|l|l|}
\hline Model & \multicolumn{1}{|c|}{$\begin{array}{c}\text { Variables } \\
\text { Entered }\end{array}$} & $\begin{array}{c}\text { Variables } \\
\text { Removed }\end{array}$ & Method \\
\hline 1 & $\begin{array}{l}\text { Zone3_Counties } \\
\text { Zone2_Counties } \\
\text { Zone1_Counties } \\
\text { Population }\end{array}$ & & \\
\hline
\end{tabular}

a. Dependent Variable: Funding

b. All requested variables entered. 
Model Summary

\begin{tabular}{|c|c|c|c|c|c|c|c|}
\hline \multirow[t]{2}{*}{ Model } & \multirow[t]{2}{*}{$\mathrm{R}$} & \multirow{2}{*}{$\begin{array}{c}\mathrm{R} \\
\text { Square }\end{array}$} & \multirow{2}{*}{$\begin{array}{l}\text { Adjusted R } \\
\text { Square }\end{array}$} & \multirow{2}{*}{$\begin{array}{l}\text { Std. Error of the } \\
\text { Estimate }\end{array}$} & \multicolumn{3}{|c|}{ Change Statistics } \\
\hline & & & & & R Square Change & F Change & df1 \\
\hline 1 & $.610^{\mathrm{a}}$ & .372 & .318 & $\$ 112,282.341$ & .372 & 6.820 & 4 \\
\hline
\end{tabular}

Model Summary ${ }^{b}$

\begin{tabular}{|l|r|r|r|}
\hline \multirow{2}{*}{ Model } & \multicolumn{2}{|c|}{ Change Statistics } & \multirow{2}{*}{ Durbin-Watson } \\
\cline { 2 - 3 } & df2 & Sig. F Change & \\
\hline 1 & $46^{\mathrm{a}}$ & & .000 \\
\hline
\end{tabular}

a. Predictors: (Constant), Zone3_Counties, Zone2_Counties, Zone1_Counties, Population

b. Dependent Variable: Funding

ANOVA $^{\mathrm{a}}$

\begin{tabular}{|c|c|c|c|c|c|}
\hline Model & Sum of Squares & $\mathrm{df}$ & Mean Square & $\mathrm{F}$ & Sig. \\
\hline $\begin{array}{l}\text { Regression } \\
\text { Residual } \\
\text { Total }\end{array}$ & $\begin{array}{r}343920325935 . \\
879 \\
579936913166 . \\
043 \\
\\
923857239101 . \\
922\end{array}$ & $\begin{array}{l}46 \\
50\end{array}$ & $\begin{array}{r}85980081483.9 \\
70 \\
12607324199.2 \\
62\end{array}$ & 6.820 & $.000^{\mathrm{b}}$ \\
\hline
\end{tabular}

a. Dependent Variable: Funding

b. Predictors: (Constant), Zone3_Counties, Zone2_Counties, Zone1_Counties, Population 


\section{Coefficients $^{\mathrm{a}}$}

\begin{tabular}{|c|c|c|c|c|c|c|}
\hline \multirow{2}{*}{\multicolumn{2}{|c|}{ Model }} & \multicolumn{2}{|c|}{ Unstandardized Coefficients } & \multirow{2}{*}{$\begin{array}{c}\begin{array}{c}\text { Standardized } \\
\text { Coefficients }\end{array} \\
\text { Beta }\end{array}$} & \multirow[t]{2}{*}{$\mathrm{t}$} & \multirow[t]{2}{*}{ Sig. } \\
\hline & & B & Std. Error & & & \\
\hline \multirow{5}{*}{1} & (Constant) & 84778.873 & 28368.217 & & 2.989 & .004 \\
\hline & Population & .008 & .003 & .383 & 2.879 & .006 \\
\hline & Zone1_Counties & 1450.672 & 681.011 & 267 & 2.130 & .039 \\
\hline & Zone2_Counties & 1538.516 & 849.232 & .223 & 1.812 & .077 \\
\hline & Zone3_Counties & -1354.984 & 503.104 & -.370 & -2.693 & .010 \\
\hline
\end{tabular}

Coefficients $^{\mathrm{a}}$

\begin{tabular}{|l|r|r|r|r|r|}
\hline \multirow{2}{*}{ Model } & \multicolumn{3}{|c|}{ Correlations } & \multicolumn{2}{c|}{ Collinearity Statistics } \\
\cline { 2 - 6 } & Zero-order & Partial & Part & \multicolumn{1}{c|}{ Tolerance } & \multicolumn{1}{c|}{ VIF } \\
\hline \multirow{2}{*}{ (Constant) } & & & & & \\
Population & .272 & .391 & .336 & .773 & 1.293 \\
& .399 & .300 & .249 & .865 & 1.155 \\
Zone1_Counties & .305 & .258 & .212 & .899 & 1.112 \\
Zone2_Counties & -.253 & -.369 & -.315 & .723 & 1.382 \\
Zone3_Counties & & & & &
\end{tabular}

a. Dependent Variable: Funding

\section{Collinearity Diagnostics ${ }^{a}$}

\begin{tabular}{|lr|r|r|r|r|r|}
\hline Model & Dimension & Eigenvalue & \multirow{2}{*}{$\begin{array}{c}\text { Condition } \\
\text { Index }\end{array}$} & \multicolumn{3}{|c|}{ Variance Proportions } \\
\cline { 4 - 6 } & & & & (Constant) & Population & Zone1_Counties \\
\hline & & 3.141 & 1.000 & .03 & .03 & .02 \\
& .953 & 1.815 & .01 & .03 & .23 \\
& & .359 & 2.958 & .00 & .10 & .27 \\
1 & .321 & 3.126 & .03 & .82 & .09 \\
& & .226 & 3.729 & .94 & .02 & .39 \\
\hline
\end{tabular}


Collinearity Diagnostics ${ }^{\mathrm{a}}$

\begin{tabular}{|c|c|c|c|}
\hline \multirow[t]{2}{*}{ Model } & \multirow[t]{2}{*}{ Dimension } & \multicolumn{2}{|c|}{ Variance Proportions } \\
\hline & & Zone2_Counties & Zone3_Counties \\
\hline \multirow{5}{*}{1} & 1 & .03 & .02 \\
\hline & 2 & .01 & .28 \\
\hline & 3 & .82 & .06 \\
\hline & 4 & .00 & .52 \\
\hline & 5 & .14 & .12 \\
\hline
\end{tabular}

a. Dependent Variable: Funding

Residuals Statistics ${ }^{\mathrm{a}}$

\begin{tabular}{|l|r|r|r|r|r|}
\hline & \multicolumn{1}{|c|}{ Minimum } & Maximum & Mean & Std. Deviation & $\mathrm{N}$ \\
\hline Predicted Value & $\$ 19,686.44$ & $\$ 379,709.69$ & $\$ 165,130.04$ & $\$ 82,936.159$ & 51 \\
Residual & $-\$ 214,518.906$ & $\$ 299,417.656$ & $\$ 0.000$ & $\$ 107,697.439$ & 51 \\
Std. Predicted Value & -1.754 & 2.587 & .000 & 1.000 & 51 \\
Std. Residual & -1.911 & 2.667 & .000 & .959 & 51 \\
\hline
\end{tabular}

a. Dependent Variable: Funding

Fiscal Year 2007

Descriptive Statistics

\begin{tabular}{|l|r|r|r|}
\hline & \multicolumn{1}{|c|}{ Mean } & Std. Deviation & $\mathrm{N}$ \\
\hline Funding & $\$ 164,634.06$ & $\$ 128,020.647$ & 51 \\
Population & 5913331.27 & 6645750.127 & 51 \\
Zone1_Counties & 20.98 & 25.064 & 51 \\
Zone2_Counties & 20.31 & 19.715 & 51 \\
Zone3_Counties & 20.33 & 37.109 & 51 \\
\hline
\end{tabular}


Correlations

\begin{tabular}{|c|c|c|c|c|c|}
\hline & Funding & Population & Zone1_Counties & Zone2_Counties \\
\hline \multirow{7}{*}{$\begin{array}{l}\text { Pearson } \\
\text { Correlation }\end{array}$} & Funding & 1.000 & .358 & .376 & .331 \\
\hline & Population & .358 & 1.000 & -.039 & .260 \\
\hline & Zone1_Counties & .376 & -.039 & 1.000 & .144 \\
\hline & Zone2_Counties & .331 & .260 & .144 & 1.000 \\
\hline & Zone3_Counties & -.141 & .435 & -.306 & .152 \\
\hline & Funding & & .005 & .003 & .009 \\
\hline & Population & .005 & & .393 & .033 \\
\hline \multirow{5}{*}{$\begin{array}{l}\text { Sig. (1- } \\
\text { tailed) }\end{array}$} & Zone1_Counties & .003 & .393 & & .157 \\
\hline & Zone2_Counties & .009 & .033 & 157 & \\
\hline & Zone3_Counties & .162 & .001 & .015 & .144 \\
\hline & Funding & 51 & 51 & 51 & 51 \\
\hline & Population & 51 & 51 & 51 & 51 \\
\hline \multirow[t]{3}{*}{$\mathrm{N}$} & Zone1_Counties & 51 & 51 & 51 & 51 \\
\hline & Zone2_Counties & 51 & 51 & 51 & 51 \\
\hline & Zone3_Counties & 51 & 51 & 51 & 51 \\
\hline
\end{tabular}




\section{Correlations}

\begin{tabular}{|c|c|c|}
\hline & & Zone3_Counties \\
\hline \multirow{6}{*}{ Pearson Correlation } & $\begin{array}{l}\text { Funding } \\
\text { Population }\end{array}$ & $\begin{array}{r}-.141 \\
.435\end{array}$ \\
\hline & Zone1_Counties & -.306 \\
\hline & Zone2_Counties & .152 \\
\hline & Zone3_Counties & 1.000 \\
\hline & Funding & .162 \\
\hline & Population & .001 \\
\hline \multirow[t]{5}{*}{ Sig. (1-tailed) } & Zone1_Counties & .015 \\
\hline & Zone2_Counties & .144 \\
\hline & Zone3_Counties & \\
\hline & Funding & 51 \\
\hline & Population & 51 \\
\hline \multirow[t]{3}{*}{$\mathrm{N}$} & Zone1_Counties & 51 \\
\hline & Zone2_Counties & 51 \\
\hline & Zone3_Counties & 51 \\
\hline
\end{tabular}

Variables Entered/Removed ${ }^{\mathrm{a}}$

\begin{tabular}{|l|l|l|l|}
\hline Model & \multicolumn{1}{|c|}{$\begin{array}{c}\text { Variables } \\
\text { Entered }\end{array}$} & $\begin{array}{c}\text { Variables } \\
\text { Removed }\end{array}$ & Method \\
\hline 1 & $\begin{array}{l}\text { Zone3_Counties } \\
\text { Zone2_Counties } \\
\text { Zone1_Counties } \\
\text { Population }\end{array}$ & & \\
\hline
\end{tabular}

a. Dependent Variable: Funding

b. All requested variables entered. 
Model Summary

\begin{tabular}{|l|r|r|r|r|r|r|r|}
\hline Model & $\mathrm{R}$ & $\mathrm{R}$ Square & \multicolumn{1}{c|}{$\begin{array}{c}\text { Adjusted } \mathrm{R} \\
\text { Square }\end{array}$} & & & $\begin{array}{l}\text { Std. Error of } \\
\text { the Estimate }\end{array}$ & \multicolumn{3}{|c|}{ Change Statistics } \\
\cline { 5 - 8 } & & & & & $\begin{array}{l}\text { R Square } \\
\text { Change }\end{array}$ & F Change & df1 \\
\hline 1 & $.609^{\mathrm{a}}$ & .371 & .316 & $\$ 105,886.485$ & .371 & 6.772 & 4 \\
\hline
\end{tabular}

Model Summary ${ }^{\mathrm{b}}$

\begin{tabular}{|c|c|c|c|}
\hline \multirow[t]{2}{*}{ Model } & \multicolumn{2}{|c|}{ Change Statistics } & \multirow[t]{2}{*}{ Durbin-Watson } \\
\hline & df2 & Sig. F Change & \\
\hline 1 & $46^{a}$ & .000 & 1.947 \\
\hline
\end{tabular}

a. Predictors: (Constant), Zone3_Counties, Zone2_Counties, Zone1_Counties, Population

b. Dependent Variable: Funding

ANOVA $^{\mathrm{a}}$

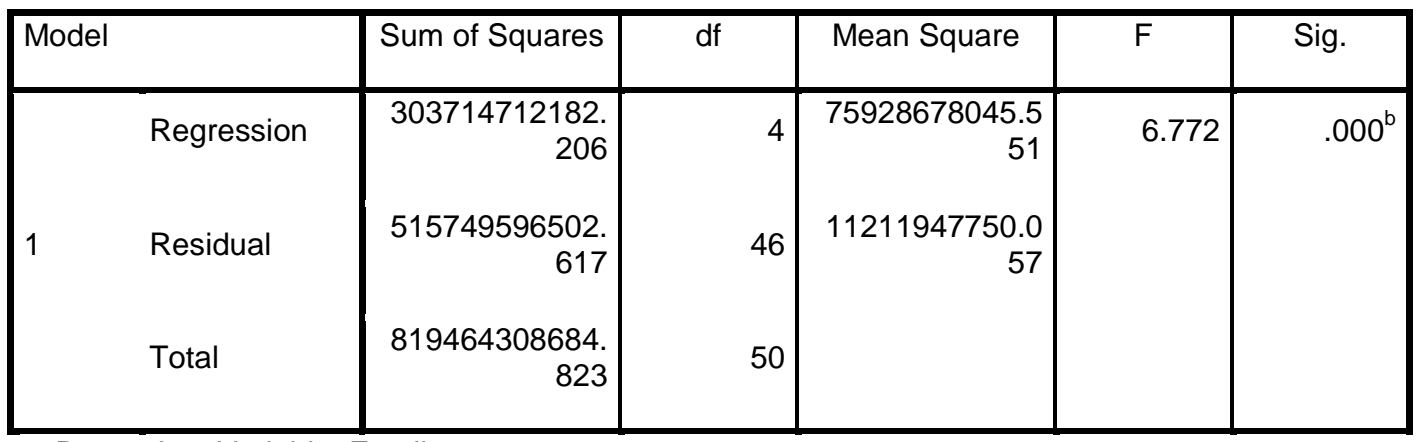

a. Dependent Variable: Funding

b. Predictors: (Constant), Zone3_Counties, Zone2_Counties, Zone1_Counties, Population 
Coefficients $^{\mathrm{a}}$

\begin{tabular}{|c|c|c|c|c|c|c|}
\hline \multirow{2}{*}{\multicolumn{2}{|c|}{ Model }} & \multicolumn{2}{|c|}{ Unstandardized Coefficients } & \multirow{2}{*}{$\begin{array}{c}\begin{array}{c}\text { Standardized } \\
\text { Coefficients }\end{array} \\
\text { Beta }\end{array}$} & \multirow[t]{2}{*}{$\mathrm{t}$} & \multirow[t]{2}{*}{ Sig. } \\
\hline & & B & Std. Error & & & \\
\hline \multirow{5}{*}{1} & (Constant) & 76206.991 & 26751.530 & & 2.849 & .007 \\
\hline & Population & .008 & .003 & .432 & 3.239 & .002 \\
\hline & Zone1_Counties & 1407.354 & 642.204 & 276 & 2.191 & .034 \\
\hline & Zone2_Counties & 1437.055 & 800.930 & 221 & 1.794 & .079 \\
\hline & Zone3_Counties & -960.605 & 475.766 & -.278 & -2.019 & .049 \\
\hline
\end{tabular}

Coefficients $^{a}$

\begin{tabular}{|l|r|r|r|r|r|}
\hline \multirow{2}{*}{ Model } & \multicolumn{3}{|c|}{ Correlations } & \multicolumn{2}{c|}{ Collinearity Statistics } \\
\cline { 2 - 6 } & Zero-order & Partial & \multicolumn{1}{c|}{ Part } & Tolerance & \multicolumn{1}{c|}{ VIF } \\
\hline \multirow{2}{*}{ (Constant) } & & & & & \\
Population & .358 & .431 & .379 & .768 & 1.302 \\
& .376 & .307 & .256 & .865 & 1.155 \\
Zone1_Counties & .331 & .256 & .210 & .899 & 1.112 \\
Zone2_Counties & -.141 & -.285 & -.236 & .719 & 1.390 \\
\hline
\end{tabular}

a. Dependent Variable: Funding

Collinearity Diagnostics ${ }^{a}$

\begin{tabular}{|c|c|c|c|c|c|c|}
\hline \multirow[t]{2}{*}{ Model } & \multirow[t]{2}{*}{ Dimension } & \multirow[t]{2}{*}{ Eigenvalue } & \multirow[t]{2}{*}{ Condition Index } & \multicolumn{3}{|c|}{ Variance Proportions } \\
\hline & & & & (Constant) & Population & $\begin{array}{c}\text { Zone1_Coun } \\
\text { ties }\end{array}$ \\
\hline \multirow{5}{*}{1} & 1 & 3.142 & 1.000 & .03 & .03 & .02 \\
\hline & 2 & .955 & 1.814 & .01 & .03 & .23 \\
\hline & 3 & .359 & 2.959 & .00 & .09 & .28 \\
\hline & 4 & .318 & 3.142 & .03 & .83 & .08 \\
\hline & 5 & .226 & 3.730 & .94 & .02 & .39 \\
\hline
\end{tabular}


Collinearity Diagnostics ${ }^{a}$

\begin{tabular}{|c|c|c|c|}
\hline \multirow[t]{2}{*}{ Model } & \multirow[t]{2}{*}{ Dimension } & \multicolumn{2}{|c|}{ Variance Proportions } \\
\hline & & Zone2_Counties & Zone3_Counties \\
\hline \multirow{5}{*}{1} & 1 & .03 & .02 \\
\hline & 2 & .01 & .27 \\
\hline & 3 & .82 & .06 \\
\hline & 4 & .00 & .52 \\
\hline & 5 & .14 & .12 \\
\hline
\end{tabular}

a. Dependent Variable: Funding

Residuals Statistics ${ }^{\mathrm{a}}$

\begin{tabular}{|l|r|r|r|r|r|}
\hline & \multicolumn{1}{|c|}{ Minimum } & Maximum & Mean & Std. Deviation & $\mathrm{N}$ \\
\hline Predicted Value & $\$ 40,947.98$ & $\$ 396,416.56$ & $\$ 164,634.06$ & $\$ 77,937.759$ & 51 \\
Residual & $-\$ 207,416.578$ & $\$ 267,526.156$ & $\$ 0.000$ & $\$ 101,562.749$ & 51 \\
Std. Predicted Value & -1.587 & 2.974 & .000 & 1.000 & 51 \\
Std. Residual & -1.959 & 2.527 & .000 & .959 & 51 \\
\hline
\end{tabular}

a. Dependent Variable: Funding

Fiscal Year 2008

Descriptive Statistics

\begin{tabular}{|l|r|r|r|}
\hline & \multicolumn{1}{|c|}{ Mean } & Std. Deviation & $\mathrm{N}$ \\
\hline Funding & $\$ 167,184.73$ & $\$ 133,369.130$ & 51 \\
Population & 5968134.24 & 6711363.558 & 51 \\
Zone1_Counties & 20.98 & 25.064 & 51 \\
Zone2_Counties & 20.31 & 19.715 & 51 \\
Zone3_Counties & 20.33 & 37.109 & 51 \\
\hline
\end{tabular}




\section{Correlations}

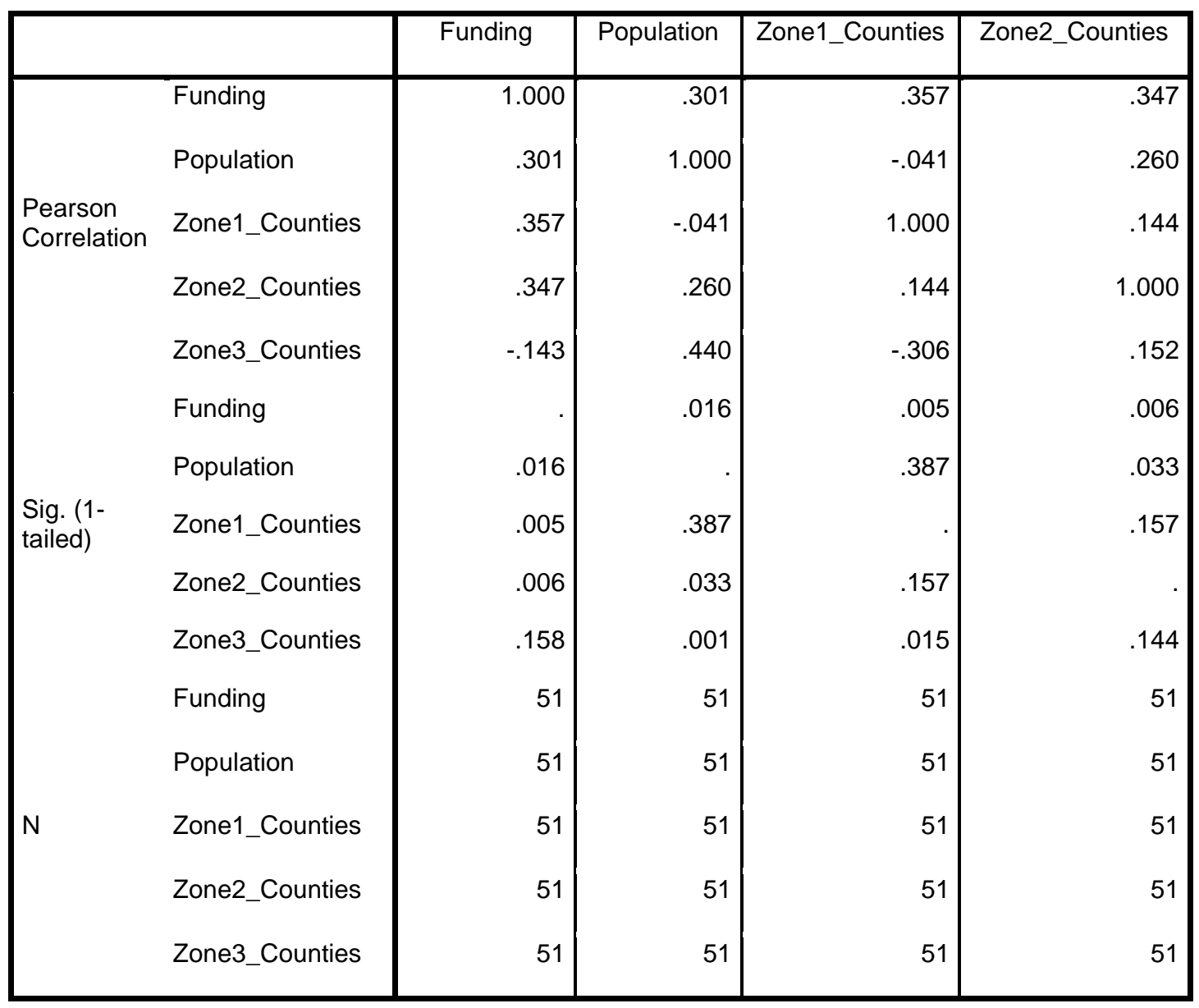




\section{Correlations}

\begin{tabular}{|c|c|c|}
\hline & & Zone3_Counties \\
\hline \multirow{6}{*}{ Pearson Correlation } & $\begin{array}{l}\text { Funding } \\
\text { Population }\end{array}$ & $\begin{array}{r}-.143 \\
.440\end{array}$ \\
\hline & Zone1_Counties & -.306 \\
\hline & Zone2_Counties & .152 \\
\hline & Zone3_Counties & 1.000 \\
\hline & Funding & .158 \\
\hline & Population & .001 \\
\hline \multirow[t]{5}{*}{ Sig. (1-tailed) } & Zone1_Counties & .015 \\
\hline & Zone2_Counties & .144 \\
\hline & Zone3_Counties & \\
\hline & Funding & 51 \\
\hline & Population & 51 \\
\hline \multirow[t]{3}{*}{$\mathrm{N}$} & Zone1_Counties & 51 \\
\hline & Zone2_Counties & 51 \\
\hline & Zone3_Counties & 51 \\
\hline
\end{tabular}

Variables Entered/Removed ${ }^{\mathrm{a}}$

\begin{tabular}{|l|l|l|l|}
\hline Model & \multicolumn{1}{|c|}{$\begin{array}{c}\text { Variables } \\
\text { Entered }\end{array}$} & $\begin{array}{c}\text { Variables } \\
\text { Removed }\end{array}$ & Method \\
\hline 1 & $\begin{array}{l}\text { Zone3_Counties } \\
\text { Zone2_Counties } \\
\text { Zone1_Counties } \\
\text { Population }\end{array}$ & & \\
\hline
\end{tabular}

a. Dependent Variable: Funding

b. All requested variables entered. 
Model Summary

\begin{tabular}{|l|l|r|r|r|r|r|r|}
\hline Model & $\mathrm{R}$ & $\begin{array}{c}\mathrm{R} \\
\end{array}$ & & Square & \multirow{2}{*}{$\begin{array}{c}\text { Adjusted R } \\
\text { Square }\end{array}$} & $\begin{array}{c}\text { Std. Error of the } \\
\text { Estimate }\end{array}$ & \multicolumn{3}{|c|}{ Change Statistics } \\
\cline { 6 - 8 } & & & & & $\begin{array}{c}\text { R Square } \\
\text { Change }\end{array}$ & F Change & df1 \\
\hline 1 & $.571^{\mathrm{a}}$ & .326 & .268 & $\$ 114,127.674$ & .326 & 5.570 & 4 \\
\hline
\end{tabular}

Model Summary ${ }^{\mathbf{b}}$

\begin{tabular}{|c|c|c|c|}
\hline \multirow[t]{2}{*}{ Model } & \multicolumn{2}{|c|}{ Change Statistics } & \multirow[t]{2}{*}{ Durbin-Watson } \\
\hline & df2 & Sig. F Change & \\
\hline 1 & $46^{\mathrm{a}}$ & .001 & 1.780 \\
\hline
\end{tabular}

a. Predictors: (Constant), Zone3_Counties, Zone2_Counties, Zone1_Counties, Population

b. Dependent Variable: Funding

ANOVA $^{\mathrm{a}}$

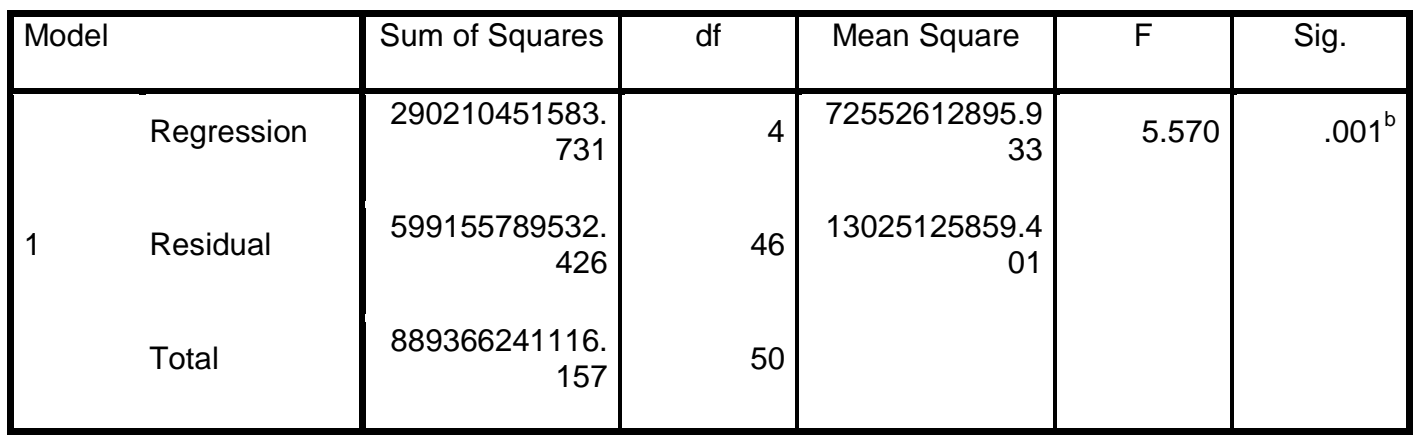

a. Dependent Variable: Funding

b. Predictors: (Constant), Zone3_Counties, Zone2_Counties, Zone1_Counties, Population 
Coefficients $^{\mathrm{a}}$

\begin{tabular}{|c|c|c|c|c|c|c|}
\hline \multirow{2}{*}{\multicolumn{2}{|c|}{ Model }} & \multicolumn{2}{|c|}{ Unstandardized Coefficients } & \multirow{2}{*}{$\begin{array}{c}\text { Standardized } \\
\text { Coefficients }\end{array}$} & \multirow[t]{2}{*}{$\mathrm{t}$} & \multirow[t]{2}{*}{ Sig. } \\
\hline & & B & Std. Error & & & \\
\hline & (Constant) & 79943.775 & 28828.262 & & 2.773 & .008 \\
\hline & Population & .007 & .003 & .361 & 2.607 & .012 \\
\hline \multirow[t]{3}{*}{1} & Zone1_Counties & 1356.996 & 692.161 & 255 & 1.961 & .056 \\
\hline & Zone2_Counties & 1732.180 & 863.304 & 256 & 2.006 & .051 \\
\hline & Zone3_Counties & -944.998 & 513.938 & -.263 & -1.839 & .072 \\
\hline
\end{tabular}

\begin{tabular}{|l|r|r|r|r|r|}
\hline \multirow{2}{*}{} & \multicolumn{3}{|c|}{ Correlations } & \multicolumn{2}{c|}{$\begin{array}{c}\text { Collinearity } \\
\text { Statistics }\end{array}$} \\
\cline { 2 - 7 } & Zero-order & \multicolumn{1}{|c|}{ Partial } & Part & Tolerance & VIF \\
\hline (Constant) & & & & & \\
Population & .301 & .359 & .316 & .764 & 1.308 \\
Zone1_Counties & .357 & .278 & .237 & .866 & 1.155 \\
Zone2_Counties & .347 & .284 & .243 & .899 & 1.112 \\
Zone3_Counties & -.143 & -.262 & -.223 & .716 & 1.396 \\
\hline
\end{tabular}

a. Dependent Variable: Funding

Collinearity Diagnostics ${ }^{a}$

\begin{tabular}{|c|c|c|c|c|c|c|}
\hline \multirow[t]{2}{*}{ Model } & \multirow[t]{2}{*}{ Dimension } & \multirow[t]{2}{*}{ Eigenvalue } & \multirow[t]{2}{*}{ Condition Index } & \multicolumn{3}{|c|}{ Variance Proportions } \\
\hline & & & & (Constant) & Population & $\begin{array}{c}\text { Zone1_Coun } \\
\text { ties }\end{array}$ \\
\hline \multirow{5}{*}{1} & 1 & 3.143 & 1.000 & .03 & .03 & .02 \\
\hline & 2 & .956 & 1.813 & .01 & .03 & .23 \\
\hline & 3 & .359 & 2.960 & .00 & .09 & .28 \\
\hline & 4 & .316 & 3.152 & .03 & .83 & .08 \\
\hline & 5 & .226 & 3.729 & .94 & .02 & .39 \\
\hline
\end{tabular}


Collinearity Diagnostics ${ }^{a}$

\begin{tabular}{|c|c|c|c|}
\hline \multirow[t]{2}{*}{ Model } & \multirow[t]{2}{*}{ Dimension } & \multicolumn{2}{|c|}{ Variance Proportions } \\
\hline & & Zone2_Counties & Zone3_Counties \\
\hline \multirow{5}{*}{1} & 1 & .0 & .02 \\
\hline & 2 & .0 & .27 \\
\hline & 3 & .8 & .06 \\
\hline & 4 & .0 & .52 \\
\hline & 5 & .14 & .12 \\
\hline
\end{tabular}

a. Dependent Variable: Funding

Residuals Statistics ${ }^{a}$

\begin{tabular}{|l|r|r|r|r|r|}
\hline & \multicolumn{1}{|c|}{ Minimum } & Maximum & Mean & Std. Deviation & $\mathrm{N}$ \\
\hline Predicted Value & $\$ 44,956.14$ & $\$ 369,700.56$ & $\$ 167,184.73$ & $\$ 76,185.360$ & 51 \\
Residual & $-\$ 180,700.578$ & $\$ 305,990.375$ & $-\$ 0.000$ & $\$ 109,467.419$ & 51 \\
Std. Predicted Value & -1.604 & 2.658 & .000 & 1.000 & 51 \\
Std. Residual & -1.583 & 2.681 & .000 & .959 & 51 \\
\hline
\end{tabular}

a. Dependent Variable: Funding 